\title{
Cervical preparation for first trimester surgical abortion (Review)
}

\author{
Kapp N, Lohr PA, Ngo TD, Hayes JL
}

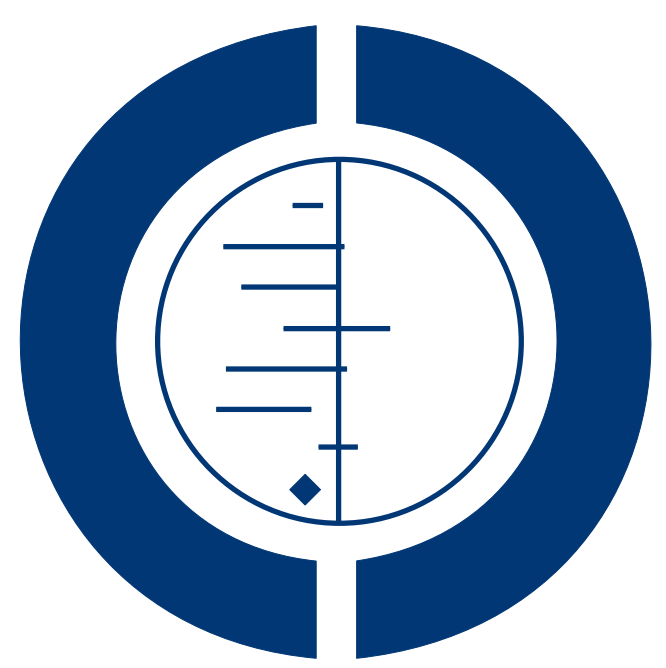

THE COCHRANE
COLLABORATION $^{\circledR}$

This is a reprint of a Cochrane review, prepared and maintained by The Cochrane Collaboration and published in The Cochrane Library 2010, Issue 2

http://www.thecochranelibrary.com

\section{WILEY}


TABLE OF CONTENTS

HEADER . . . . . . . . . . . . . . . . . . . . . . . . . . . . . . . . . . . . . . . . . . . . . . . . . 1

ABSTRACT . . . . . . . . . . . . . . . . . . . . . . . . . . . . . . . . . . . . . . . . . . . . . . . . . . . . . . .

PLAIN LANGUAGE SUMMARY . . . . . . . . . . . . . . . . . . . . . . . . . . . . . . . . . . . . . . . . . . .

BACKGROUND . . . . . . . . . . . . . . . . . . . . . . . . . . . . . . . . . . . . . 2

OBJECTIVES . . . . . . . . . . . . . . . . . . . . . . . . . . . . . . . . . . . . . . . . . . . . . . . . .

METHODS . . . . . . . . . . . . . . . . . . . . . . . . . . . . . . . . . . . . . . . 3

RESULTS . . . . . . . . . . . . . . . . . . . . . . . . . . . . . . . . . . . . . . . . . . . . . . . . .

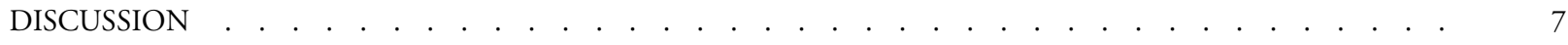

AUTHORS' CONCLUSIONS . . . . . . . . . . . . . . . . . . . . . . . . . . . . . . . . . . . . . . . . .

ACKNOWLEDGEMENTS . . . . . . . . . . . . . . . . . . . . . . . . . . . . . . . . . . . . . . . . . . . . . .

REFERENCES . . . . . . . . . . . . . . . . . . . . . . . . . . . . . . . . . . . . . . . . . . . . . . . . .

CHARACTERISTICS OF STUDIES . . . . . . . . . . . . . . . . . . . . . . . . . . . . . . . . . . . . . . . . . .

DATA AND ANALYSES . . . . . . . . . . . . . . . . . . . . . . . . . . . . . . . . . . . . . . . . . . . . 39

Analysis 1.1. Comparison 1 Misoprostol versus placebo, Outcome 1 Cervical dilation at procedure start. . . . . . . 47

Analysis 1.2. Comparison 1 Misoprostol versus placebo, Outcome 2 Side-effects: occurrence of nausea. $\quad$. . . . . . . 48

Analysis 1.3. Comparison 1 Misoprostol versus placebo, Outcome 3 Procedure length (minutes). . . . . . . . . . 49

Analysis 2.1. Comparison 2 Gemeprost $1 \mathrm{mg}$ versus placebo, Outcome 1 Need for additional mechanical dilation. $\quad . \quad 50$

Analysis 3.1. Comparison 3 Mifepristone versus placebo, Outcome 1 Need for additional mechanical dilation. $\quad$. $\quad 51$

Analysis 3.2. Comparison 3 Mifepristone versus placebo, Outcome 2 Cervical dilation at procedure start. $\quad$. . . $\quad$. 52

Analysis 4.1. Comparison 4 Prostaglandin F2 $\alpha$ versus placebo, Outcome 1 Need for additional mechanical dilation. 53

Analysis 5.1. Comparison 5 Prostaglandin E2 versus placebo, Outcome 1 Need for additional mechanical dilation. .54

Analysis 5.2. Comparison 5 Prostaglandin E2 versus placebo, Outcome 2 Cervical dilation at procedure start. . . . . 55

Analysis 6.1. Comparison 6 Osmotic dilators versus placebo, Outcome 1 Cervical dilation at procedure start. . . . . 56

Analysis 7.1. Comparison 7 Misoprostol dose: $400 \mu \mathrm{g}$ misoprostol versus $200 \mu \mathrm{g}$ misoprostol, Outcome 1 Cervical dilation at procedure start. . . . . . . . . . . . . . . . . . . . . . . . . . . . . . . . . . . . . . . 57

Analysis 7.2. Comparison 7 Misoprostol dose: $400 \mu \mathrm{g}$ misoprostol versus $200 \mu \mathrm{g}$ misoprostol, Outcome 2 Need for additional mechanical dilation. . . . . . . . . . . . . . . . . . . . . . . . . . . . . . .

Analysis 7.3. Comparison 7 Misoprostol dose: $400 \mu \mathrm{g}$ misoprostol versus $200 \mu \mathrm{g}$ misoprostol, Outcome 3 Pain with cervical priming.

Analysis 7.4. Comparison 7 Misoprostol dose: $400 \mu \mathrm{g}$ misoprostol versus $200 \mu \mathrm{g}$ misoprostol, Outcome 4 Procedure length (minutes).

Analysis 8.1. Comparison 8 Interval between misoprostol application and procedure: 2 hours versus 3 hours, Outcome 1 Cervical dilation at procedure start.

Analysis 8.2. Comparison 8 Interval between misoprostol application and procedure: 2 hours versus 3 hours, Outcome 2 Need for additional mechanical dilation.

Analysis 8.3. Comparison 8 Interval between misoprostol application and procedure: 2 hours versus 3 hours, Outcome 3

Pain with cervical priming.

Analysis 9.1. Comparison 9 Route of misoprostol administration, Outcome 1 Cervical dilation at procedure start.

Analysis 9.2. Comparison 9 Route of misoprostol administration, Outcome 2 Need for additional mechanical dilation.

Analysis 9.3. Comparison 9 Route of misoprostol administration, Outcome 3 Side-effects: occurrence of nausea. . .

Analysis 9.4. Comparison 9 Route of misoprostol administration, Outcome 4 Cervical dilation at procedure start.

Analysis 9.5. Comparison 9 Route of misoprostol administration, Outcome 5 Procedure length (minutes). . . . .

Analysis 9.6. Comparison 9 Route of misoprostol administration, Outcome 6 Patient disatisfaction. . . . . . . . .

Analysis 10.1. Comparison 10 Misoprostol versus gemeprost, Outcome 1 Cervical dilation at procedure start. . . . .

Analysis 10.2. Comparison 10 Misoprostol versus gemeprost, Outcome 2 Side-effects of $200 \mu \mathrm{g}$ misoprostol versus gemeprost. . . . . . . . . . . . . . . . . . . . . . . . . . . . . . . . . . . .

Analysis 10.3. Comparison 10 Misoprostol versus gemeprost, Outcome 3 Side-effects of 400 misoprostol versus gemeprost. . . . . . . . . . . . . . . . . . . . . . . . . . . . . . . . . . . . . 
Analysis 12.1. Comparison 12 Misoprostol versus laminaria, Outcome 1 Need for additional mechanical dilation.

Analysis 12.2. Comparison 12 Misoprostol versus laminaria, Outcome 2 Procedure length (minutes). . . . . . .

Analysis 12.3. Comparison 12 Misoprostol versus laminaria, Outcome 3 Patient disatisfaction. . . . . . . . . . . .

Analysis 13.1. Comparison 13 Misoprostol versus prostaglandin F2 $\alpha$, Outcome 1 Need for additional mechanical dilation. . . . . . . . . . . . . . . . . . . . . . . . . . . . . . . . . . . . . . .

Analysis 13.2. Comparison 13 Misoprostol versus prostaglandin F2 $\alpha$, Outcome 2 Cervical dilation at procedure start. Analysis 13.3. Comparison 13 Misoprostol versus prostaglandin F2 $\alpha$, Outcome 3 Side-effects: nausea and vomiting. Analysis 13.4. Comparison 13 Misoprostol versus prostaglandin F2 $\alpha$, Outcome 4 Procedure length (minutes). . . Analysis 13.5. Comparison 13 Misoprostol versus prostaglandin F2 $\alpha$, Outcome 5 Patient disatisfaction. . . . . . Analysis 14.1. Comparison 14 Gemeprost $1 \mathrm{mg}$ versus Lamicel, Outcome 1 Need for additional mechanical dilation. Analysis 14.2. Comparison 14 Gemeprost $1 \mathrm{mg}$ versus Lamicel, Outcome 2 Side-effects.

Analysis 15.1. Comparison 15 Gemeprost versus Dilapan, Outcome 1 Need for additional mechanical dilation. Analysis 15.2. Comparison 15 Gemeprost versus Dilapan, Outcome 2 Side-effects. . . . . . . . . . . . . . . . . Analysis 16.1. Comparison 16 Gemeprost versus laminaria, Outcome 1 Need for additional mechanical dilation. . . Analysis 16.2. Comparison 16 Gemeprost versus laminaria, Outcome 2 Cervical dilation at procedure start. . . . Analysis 16.3. Comparison 16 Gemeprost versus laminaria, Outcome 3 Side-effects: nausea and vomiting. . . . . Analysis 17.1. Comparison 17 Gemeprost versus prostaglandin F2 $\alpha$, Outcome 1 Need for additional mechanical dilation. Analysis 17.2. Comparison 17 Gemeprost versus prostaglandin F2 $\alpha$, Outcome 2 Cervical dilation at procedure start. Analysis 17.3. Comparison 17 Gemeprost versus prostaglandin F2 $\alpha$, Outcome 3 Side-effects: nausea and vomiting. . Analysis 18.1. Comparison 18 Dose of mifepristone, Outcome 1 Need for additional mechanical dilation. . . . . . Analysis 18.2. Comparison 18 Dose of mifepristone, Outcome 2 Cervical dilation at procedure start. . . . . . . . Analysis 19.1. Comparison 19 Laminaria versus prostaglandin F2 $\alpha$, Outcome 1 Cervical dilation at procedure start. Analysis 19.2. Comparison 19 Laminaria versus prostaglandin F2 $\alpha$, Outcome 2 Unplanned expulsion prior to procedure. Analysis 20.1. Comparison 20 Laminaria versus sulprostone, Outcome 1 Cervical dilation at procedure start. . . . Analysis 20.2. Comparison 20 Laminaria versus sulprostone, Outcome 2 Need for additional mechanical dilation. . Analysis 20.3. Comparison 20 Laminaria versus sulprostone, Outcome 3 Side-effects: nausea and vomiting. . . . . Analysis 21.1. Comparison 21 Laminaria versus PGE2, Outcome 1 Cervical dilation at procedure start. . . . . . . Analysis 21.2. Comparison 21 Laminaria versus PGE2, Outcome 2 Need for additional mechanical dilation. . . . Analysis 21.3. Comparison 21 Laminaria versus PGE2, Outcome 3 Side-effects: nausea and vomiting. . . . . . . Analysis 22.1. Comparison 22 Sulprostone versus sulprostone (intracervical doses), Outcome 1 Need for additional mechanical dilation.

Analysis 22.2. Comparison 22 Sulprostone versus sulprostone (intracervical doses), Outcome 2 Side-effects: nausea and vomiting.

Analysis 22.3. Comparison 22 Sulprostone versus sulprostone (intracervical doses), Outcome 3 Unplanned expulsion prior to procedure.

Analysis 23.1. Comparison 23 Sulprostone versus sulprostone (intramuscular doses), Outcome 1 Need for additional mechanical dilation.

Analysis 23.2. Comparison 23 Sulprostone versus sulprostone (intramuscular doses), Outcome 2 Side-effects: nausea and vomiting.

Analysis 23.3. Comparison 23 Sulprostone versus sulprostone (intramuscular doses), Outcome 3 Unplanned expulsion prior to procedure.

Analysis 24.1. Comparison 24 Prostaglandin E2 versus prostaglandin F2 $\alpha$, Outcome 1 Need for additional mechanical dilation.

Analysis 24.2. Comparison 24 Prostaglandin E2 versus prostaglandin F2 $\alpha$, Outcome 2 Side-effects: nausea and vomiting.

Analysis 24.3. Comparison 24 Prostaglandin E2 versus prostaglandin F2 $\alpha$, Outcome 3 Unplanned expulsion prior to procedure.

Analysis 25.1. Comparison 25 Lamicel versus synthetic sponge without MgSO4, Outcome 1 Unplanned expulsion prior to

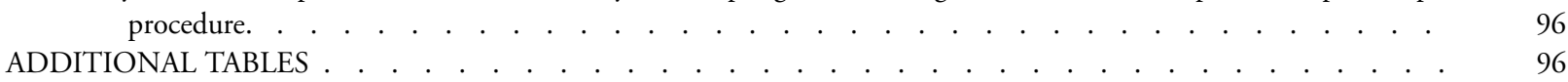

WHAT'S NEW . . . . . . . . . . . . . . . . . . . . . . . . . . . . . . . . . . . . . . . . . . . . . 99

HISTORY . . . . . . . . . . . . . . . . . . . . . . . . . . . . . . . . . . . . . . . . . . . . . . . . 9.99

CONTRIBUTIONS OF AUTHORS . . . . . . . . . . . . . . . . . . . . . . . . . . . . . . . . . . . . . . . . . . . . . . .

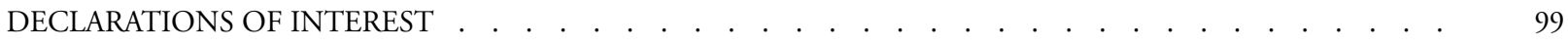

Cervical preparation for first trimester surgical abortion (Review)

Copyright $\odot 2010$ The Cochrane Collaboration. Published by John Wiley \& Sons, Ltd. 
SOURCES OF SUPPORT . . . . . . . . . . . . . . . . . . . . . . . . . . . . . . . . . . . . . . . . . . . 99

DIFFERENCES BETWEEN PROTOCOL AND REVIEW . . . . . . . . . . . . . . . . . . . . . . . . . 100

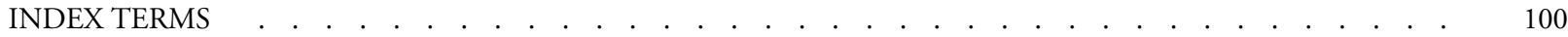




\title{
[Intervention Review]
}

\section{Cervical preparation for first trimester surgical abortion}

\author{
Nathalie Kapp ${ }^{1}$, Patricia A. Lohr ${ }^{2}$, Thoai D Ngo ${ }^{3}$, Jennifer L Hayes ${ }^{4}$ \\ ${ }^{1}$ Department of Reproductive Health and Research, World Health Organization, Geneva 27, Switzerland. ${ }^{2}$ BPAS, Stratford Upon \\ Avon, UK. ${ }^{3}$ Department of Epidemiology \& Population Health, London School of Hygiene \& Tropical Medicine, London, UK. \\ ${ }^{4}$ Obstetrics, Gynecology, and Reproductive Sciences, University of Pittsburgh, Pittsburgh, PA, USA \\ Contact address: Nathalie Kapp, Department of Reproductive Health and Research, World Health Organization, 20 Rue Appia, Geneva \\ 27, CH-1211, Switzerland. kappn@who.int.
}

Editorial group: Cochrane Fertility Regulation Group.

Publication status and date: Edited (no change to conclusions), published in Issue 3, 2010.

Review content assessed as up-to-date: 9 October 2009.

Citation: Kapp N, Lohr PA, Ngo TD, Hayes JL. Cervical preparation for first trimester surgical abortion. Cochrane Database of Systematic Reviews 2010, Issue 2. Art. No.: CD007207. DOI: 10.1002/14651858.CD007207.pub2.

Copyright (C) 2010 The Cochrane Collaboration. Published by John Wiley \& Sons, Ltd.

\begin{abstract}
A B S T R A C T
Background

Preparing the cervix prior to surgical abortion is intended to make the procedure both easier and safer. Options for cervical preparation include osmotic dilators and pharmacologic agents. Many formulations and regimens are available, and recommendations from professional organizations vary for the use of preparatory techniques in women of different ages, parity or gestational age of the pregnancy.
\end{abstract}

\section{Objectives}

To determine whether cervical preparation is necessary in the first trimester, and if so, which preparatory agent is preferred.

\section{Search methods}

We searched Cochrane, Popline, Embase, Medline and Lilacs databases for randomised controlled trials investigating the use of cervical preparatory techniques prior to first trimester surgical abortion. In addition, we hand-searched key references and contacted authors to locate unpublished studies or studies not identified in the database searches.

\section{Selection criteria}

Randomised controlled trials investigating any pharmacologic or mechanical method of cervical preparation, with the exception of nitric oxide donors (the subject of another Cochrane review), administered prior to first trimester surgical abortion were included. Outcome measures must have included the amount of cervical dilation achieved, the procedure duration or difficulty, side-effects, patient satisfaction or adverse events to be included in this review.

\section{Data collection and analysis}

Trials under consideration were evaluated by considering whether inclusion criteria were met as well as methodologic quality. Fiftyone studies were included, resulting in 24 different cervical preparation comparisons. Results are reported as odds ratios (OR) for dichotomous outcomes and weighted mean differences for continuous data.

Cervical preparation for first trimester surgical abortion (Review)

Copyright $\odot 2010$ The Cochrane Collaboration. Published by John Wiley \& Sons, Ltd. 


\section{Main results}

When compared to placebo, misoprostol (400-600 $\mu \mathrm{g}$ given vaginally or sublingually), gemeprost, mifepristone (200 or $600 \mathrm{mg}$ ), prostaglandin $\mathrm{E}$ and $\mathrm{F}_{2 \alpha}$ (2.5 mg administered intracervically) demonstrated

larger cervical preparation effects. When misoprostol was compared to gemeprost, misoprostol was more effective in preparing the cervix and was associated with fewer gastrointestinal side-effects. For vaginal administration, administration 2 hours prior was less effective than administration 3 hours prior to the abortion. Compared to oral misoprostol administration, the vaginal route was associated with significantly greater initial cervical dilation and lower rates of side-effects; however, sublingual administration 2-3 hours prior to the procedure demonstrated cervical effects superior to vaginal administration.

When misoprostol $(600 \mu \mathrm{g}$ oral or $800 \mu \mathrm{g}$ vaginal) was compared to mifepristone (200 mg administered 24 hours prior to procedure), misoprostol had inferior cervical preparatory effects. Compared to day-prior laminaria tents, 200 or $400 \mu \mathrm{g}$ vaginal misoprostol showed no differences in the need for further mechanical dilation or length of the procedure; similarly, the osmotic dilators Lamicel and Dilapan showed no differences in cervical ripening when compared to gemeprost, although gemeprost had cervical effects which were superior to laminaria tents. Older prostaglandin regimens (sulprostone, prostaglandin $\mathrm{E}_{2}$ and

$\mathrm{F}_{2 \alpha}$ ) were associated with high rates of gastrointestinal side-effects and unplanned pregnancy expulsions. Few studies reported women's satisfaction with cervical preparatory techniques.

\section{Authors' conclusions}

Modern methods of cervical ripening are generally safe, although efficacy and side-effects between methods vary. Reports of adverse events such as cervical laceration or uterine perforation are uncommon overall in this body of evidence and no published study has investigated whether cervical preparation impacts these rare outcomes. Cervical preparation decreases the length of the abortion procedure; this may become increasingly important with increasing gestational age, as mechanical dilation at later gestational ages takes longer and becomes more difficult. These data do not suggest a gestational age where the benefits of cervical dilation outweigh the side-effects, including pain, that women experience with cervical ripening procedures or the prolongation of the time interval before procedure completion. Mifepristone $200 \mathrm{mg}$, osmotic dilators and misoprostol, 400 $\mu \mathrm{g}$ administered either vaginally or sublingually, are the most effective methods of cervical preparation.

\section{PLAIN LANGUAGE SUMMARY}

\section{Preparing the cervix before first trimester surgical abortion}

Preparing the cervix to make it softer and more open before a woman has an abortion may make the procedure easier and safer. There are different techniques for preparing the cervix before abortion, including several types of medications taken either by mouth, injection or placed in the vagina, as well as several types of small rods that can be placed within the cervix. This review found that cervical preparation decreased the length of time necessary for an abortion procedure, but did not seem to decrease rates of uncommon abortion complications. The medication called misoprostol worked better with less side-effects than other similar medications. Misoprostol is most effective with the least side-effects when placed in the vagina, but when placed under the tongue it is equally effective. Another drug called mifepristone worked better than misoprostol; however, it is more expensive to use. All methods of preparation take at least 2-3 hours or more to work. The review could not determine whether women preferred one method best.

\section{B A C K G R O U N D}

Vacuum aspiration is a common method of first-trimester abortion worldwide. First-trimester surgical abortion has a low-risk of complications [Hakim-Elahi 1990] however, cervical injury, bleeding, uterine perforation, and incomplete evacuation can occur [Cates 1983; Kulier 2001]. Risk factors for these complications include provider inexperience, increased gestational age, and abnormal uterine anatomy [RCOG 1985, Hakim-Elahi 1990].

Cervical preparation for first trimester surgical abortion (Review)

Copyright $\odot 2010$ The Cochrane Collaboration. Published by John Wiley \& Sons, Ltd. 
Cervical preparation may reduce the complications of uterine perforation and cervical injury. In addition, cervical preparation may make the procedure shorter in duration, more comfortable for the woman, and easier to perform. For these reasons, the guidelines of the Royal College of Obstetricians and Gynaecologists (RCOG) state "cervical preparation is beneficial prior to surgical abortion and should be routine if the woman is aged under 18 years of age or at a gestation of more than 10 weeks" [RCOG 2004]. Similarly, the World Health Organization recommends cervical preparation for women with durations of pregnancy over 9 completed weeks for nulliparous women, for women younger than 18 years old and for all women with durations of pregnancy over 12 completed weeks [WHO 2003].

Options for cervical preparation include osmotic dilators and pharmacologic agents. Osmotic dilators are able to produce wide cervical dilation in a predictable fashion. Isaptent, the Nelaton catheter and the vibrodilator were mechanical dilators used in the past [Khanna 1980, Manabe 1981, Ng 1973]. Current devices include laminaria, Lamicel $\AA$, and Dilapan-S $₫$. Pharmacologic agents such as misoprostol, gemeprost, mifepristone, and sodium nitroprusside, soften the cervix and allow for easier, less forceful, cervical dilation.

This review includes data from all available randomized controlled trials regarding cervical preparation in first trimester abortion with the goal of answering whether preparation is needed at all, and if so, which preparatory agent is preferred.

\section{O B J E C T I VES}

To compare the effect of different methods of cervical preparation used prior to first trimester surgical abortion on the amount of cervical dilation achieved, length of procedure, side-effects, satisfaction, and safety. Included trials will be those evaluating cervical preparation versus no preparation as well as comparisons between methods.

\section{METHODS}

\section{Criteria for considering studies for this review}

\section{Types of studies}

Only randomized controlled trials are included in this review.

\section{Types of participants}

Pregnant women undergoing surgical abortion at less than 14 weeks gestation.

\section{Types of interventions}

Any type of cervical preparation, pharmacologic or mechanical, excluding nitric oxide donors, administered prior to first trimester surgical abortion.

\section{Types of outcome measures}

- Amount of cervical dilation achieved (passage of largest dilator without resistance, pressure required to pass dilator)

- Procedure duration

- Procedure difficulty (various subjective scoring of providers)

- Side effects (nausea, vomiting, fever, chills, diarrhea)

- Patient's satisfaction

- Adverse events (cervical injury [laceration, perforation, false passage], hemorrhage (intraoperative and postoperative), uterine perforation, incomplete abortion, infection [febrile morbidity, need for therapeutic antibiotics], hospital admission)

\section{Search methods for identification of studies}

See: Cochrane Fertility Regulation Group methods used in reviews (www.lumc.nl/1060/cochrane/)

See: Cochrane Fertility Regulation Group search strategy. We searched the computerized databases-Cochrane Central Register of Controlled Trials, MEDLINE, EMBASE, and POPLINE for articles for trials of cervical preparation in first trimester surgical abortion. We will contact corresponding authors of all included published trials to seek other trials we might have missed. We also will search the reference lists of included trials.

MEDLINE search used the strategy:

(first trimester OR pregnancy trimester, first) AND (abortion, induced OR abortion, legal OR abortion, therapeutic OR pregnancy termination OR termination of pregnancy) AND (surgical abortion OR dilation and curettage OR curettage OR vacuum aspiration OR suction aspiration OR suction evacuation) AND (cervical priming OR cervical ripening OR cervical dilation OR antiprogesterone OR mifepristone OR mifegyne OR RU 486 OR prostaglandin OR misoprostol OR dinoprostone OR carboprost OR sulprostone OR gemeprost OR meteneprost OR nitroglycerin OR lamicel or laminaria OR dilapan OR osmotic dilator OR laminaria tent) AND (randomized controlled trial [pt] OR controlled clinical trial [pt] OR randomized controlled trials [mh] OR random allocation [mh] OR double-blind method [mh] OR singleblind method [mh] OR clinical trial [pt] OR clinical trials [mh] OR ("clinical trial” [tw]) OR ((singl* [tw] OR doubl* [tw] OR trebl* [tw] OR tripl* [tw]) AND (mask* [tw] OR blind* [tw])) OR (placebos [mh] OR placebo* [tw] OR random* [tw] OR research design [mh:noexp] OR comparative study [mh] OR evaluation studies [mh] OR follow-up studies [mh] OR prospective studies $[\mathrm{mh}]$ OR control* $[\mathrm{tw}]$ OR prospective* $[\mathrm{tw}]$ OR volunteer* $[\mathrm{tw}])$ NOT (animals [mh] NOT human $[\mathrm{mh}])$ )

The POPLINE search used the strategy: 
(Abortion \& Pregnancy, first trimester) \& (studies / clinical trials) The Cochrane Central Register of Controlled Trials search used the strategy:

Abortion AND (first-trimester OR first trimester OR firsttrimester OR pregnancy trimester, first OR gestational age)

The EMBASE search used the strategy:

(Abortion OR Therapeutic abortion) AND (First trimester abortion OR Gestational age) AND

(cervical priming OR cervical ripening OR cervical dilation OR laminaria OR dilapan OR osmotic dilator) AND (Randomized controlled trial OR Controlled study OR Clinical trial OR Randomization OR Double blind procedure OR Single blind procedure OR Methodology OR Comparative study OR Evaluation OR Follow-up OR Prospective study OR Crossover procedure OR (singl* OR doubl* OR trebl* OR tripl*) near (mask* OR blind*) in TI, AB OR Placebo* OR Random* OR control* OR Prospectiv* OR Volunteer*) AND Human

\section{Data collection and analysis}

Two independent reviewers evaluated the titles and abstracts identified from the literature searches and assessed relevant articles for inclusion. First trimester surgical abortion was defined as an abortion performed before 14 weeks gestation with either electric or manual vacuum aspiration, or dilation and curettage. The trials were critically appraised without consideration of their results by examining the following factors: study design, randomisation method, group allocation concealment, exclusions after randomisation, loss-to-follow-up, and early discontinuation. A score for concealment of allocation was assigned to each trial, per the criteria outlined in the Cochrane Handbook:

A) adequate concealment of allocation

B) unclear whether adequate concealment of allocation

C) inadequate concealment of allocation

Only trials scoring A or B were included in the review.

Data extraction was performed independently by two reviewers (NK, TD). Data such as country, setting, sponsor and outcomes of interest were extracted using a form designed to capture these data. Discrepencies were reviewed and resolved by the two individuals extracting the data.

The data were analyzed using RevMan 5.0 software.

\section{RES U L T S}

\section{Description of studies}

See: Characteristics of included studies; Characteristics of excluded studies; Characteristics of ongoing studies.
See: Characteristics of included studies; Characteristics of excluded studies; Characteristics of studies awaiting classification.

From the search strategy described above, 51 studies met inclusion criteria for this review, resulting in 24 comparisons of cervical preparation.

\section{Risk of bias in included studies}

Randomisation and allocation methods were not further described in many studies; we attempted to contact the authors in these cases to clarify their methods. The number of trials which reported using both adequate randomisation and allocation concealment methods (whether published or by direct communication with the author) is 17; the remainder of studies stated they were randomised, but did not specify the method or had an unclear method of allocation. Loss to follow-up and post-randomisation exclusion data were collected from the included studies; no study had rates of $>10 \%$.

\section{Effects of interventions}

Comparisons to placebo (Analysis 1.1; Analysis 1.2; Analysis 1.3; Analysis 2.1; Analysis 3.1; Analysis 3.2; Analysis 4.1; Analysis 5.1; Analysis 5.2; Analysis 6.1; Table 1, Table 2)

There were significant differences in initial cervical dilation and/ or need for further cervical dilation at the time of surgical abortion when misoprostol (400-600 $\mu$ g given vaginally or sublingually), gemeprost, mifepristone (200 or $600 \mathrm{mg}$ ), prostaglandin $\mathrm{E}$ and $\mathrm{F}_{2 \alpha}$ (2.5 mg intracervical) were compared to placebos among 18 different studies. Additionally, the length of the procedure was decreased with use of misoprostol when compared to placebo (mean difference -1.09 [95\% CI -1.55, -0.64]) although side-effects, such as nausea, were generally higher in the misoprostol group.

\section{Misoprostol comparisons}

Dose of misoprostol (Analysis 7.1; Analysis 7.2; Analysis 7.3)

Improved initial cervical dilation was demonstrated with $400 \mu \mathrm{g}$ oral misoprostol when compared with $200 \mu \mathrm{g}$ (mean difference 0.53 [95\% CI 0.30, 0.77]) (Ngai 1999; Oppegaard 2004). When the same doses were administered vaginally, similar results were found (mean difference 0.92 [95\% CI 0.53, 1.31]), although significant heterogeneity is present between these data from two trials (Ngai 1999; Singh 1998). dilation was also greater with a 400 $\mu \mathrm{g}$ dose of sublingual misoprostol compared to $200 \mu \mathrm{g}$ (mean difference 2.20 [1.61, 2.79]) (Vimala, Mittal 2004). With a $400 \mu \mathrm{g}$ dose of sublingual misoprostol, the abortion procedure took less time (RR - 1.22 [95\% CI -1.72, -0.71]); however, women reported more pain (RR 2.50 [95\% CI 1.31, 4.75]) than those who received a $200 \mu \mathrm{g}$ dose.

Timing of misoprostol (Analysis 8.1; Analysis 8.2; Analysis 8.3)

The effect of the interval between misoprostol administration and the procedure on cervical priming was investigated in one study

Cervical preparation for first trimester surgical abortion (Review) 
(Singh 1999). A significant improvement in initial cervical dilation (mean difference1.50 [95\% CI 1.42, 1.58]) and less need for further dilation (RR 0.01 [95\% CI 0.00, 0.08]) was demonstrated with an interval of 3 hours after $400 \mu \mathrm{g}$ of vaginal misoprostol when compared with an interval of 2 hours after $600 \mu \mathrm{g}$ vaginal misoprostol. Women who received $600 \mu \mathrm{g}$ also reported pain with cervical priming more frequently (RR 0.10 [95\% CI 0.02, 0.39]) than women who received $400 \mu \mathrm{g}$ of misoprostol.

Route of administration of misoprostol (Analysis 9.1; Analysis 9.2; Analysis 9.3; Analysis 9.4; Analysis 9.5; Analysis 9.6)

Vaginal versus oral

Many studies have compared the vaginal and oral routes of misoprostol administration. Three studies used $400 \mu \mathrm{g}$, and were included in a meta-analysis (Cakir 2005; Ngai 1999). Three other studies compared doses ranging from 200 to $800 \mu \mathrm{g}$ or assessed differing times of administration between oral and vaginal administration using the same dose (Ashok 2003; Carbonell 2001; Inal 2003; Oppegaard 2006). These studies are summarised in Table 3. Compared to oral administration, the vaginal route was associated with significantly greater initial cervical dilation (mean difference 0.50 [95\% CI 0.13, 0.87]) in the meta-analysis.

Vaginal versus sublingual

Sublingual versus vaginal administration of $400 \mu \mathrm{g}$ misoprostol has been compared in four studies (Esteve 2006; Tang 2004; Vimala 2004, Hamoda 2004). One study was not included in the metaanalysis of cervical effect as its data were reported incompletely (Hamoda 2004, Table 3). In the meta-anlaysis, significant heterogeneity was noted. A sensitivity analysis demonstrated that without the data from Vimala 2004 the effect estimate was -0.09 [95\% CI $-0.18,-0.01]$ in favor of sublingual application of misoprostol administered for 2-3 hours. When all studies were included in the analysis, the overall estimate of effect was larger, but consistent in demonstrating a greater effect on initial cervical dilation of sublingual misoprostol (mean difference -0.10 [95\% CI -0.19, -0.01]) than vaginal misoprostol administration.

Sublingual misoprostol was similarly found to be associated with less need for further dilation (RR 1.41 [95\% CI 1.15, 1.73]) than with vaginal misoprostol, in a meta-analysis. Sublingual administration was also associated with a higher occurrence of nausea than vaginal administration (RR 0.33 [95\% CI 0.22, 0.49]), although no significant differences were noted between oral and vaginal groups (RR 0.59 [95\% CI 0.26, 1.37]). Additionally, sublingual administration demonstrated significantly shorter procedure times (mean difference 0.38 [95\% CI 0.11, 0.65]) when compared to vaginal administration while no differences in procedure length were noted between vaginal and oral administration.

One small study (Hamoda 2004) attempted to address women's level of satisfaction with her cervical ripening method; no differences in disatisfaction were noted between those who received misoprostol vaginally when compared with those who received it sublingually (RR 0.10 [95\% CI 0.01, 1.97]).

Misoprostol versus gemeprost (Analysis 10.1; Analysis 10.2; Analysis
10.3; Analysis 10.4; Table 4)

Misoprostol, $400 \mu \mathrm{g}$, when compared to gemeprost, $1 \mathrm{mg}$, appears to be superior in terms of cervical dilation effect (mean difference 0.53 [95\% CI 0.03, 1.04]) among 2 trials included in the metaanalysis (Ekerhovd 2003; Ngai, Yeung 1995), whereas $200 \mu \mathrm{g}$ misoprostol had similar effects to $1 \mathrm{mg}$ gemeprost (mean difference 0.40 [95\% CI -0.16, 0.96] [Henry 1999]). One study, which could not be included in the meta-analysis, demonstrated no difference between $600 \mu \mathrm{g}$ of misoprostol and gemeprost (El-Rafaey 1994). In comparison to gemeprost, misoprostol, $400 \mu \mathrm{g}$, had lower overall rates of gastrointestinal side-effects (RR 0.35 [95\% CI 0.18, $0.68]$ ); a similar effect estimate was found when $200 \mu \mathrm{g}$ misoprostol was used (RR 0.35 [95\% CI 0.18, 0.68]). The length of the procedure was significantly reduced with $400 \mu \mathrm{g}$ misoprostol, when compared to gemeprost (mean differerence -1.50 [95\% CI $-3.00,0.00])$.

Misoprostol versus mifepristone (Analysis 11.1; Analysis 11.2)

Mifepristone, $200 \mathrm{mg}$ given 24 hours prior to the procedure, had a greater cervical ripening effect than misoprostol, $600 \mu \mathrm{g}$ orally or $800 \mu \mathrm{g}$ vaginally (mean difference -0.79 [95\% CI -1.29, -0.30] [ Ashok 2000; Bokstrom 1998]).No differences in nausea/vomiting between the treatment groups were reported (RR 0.75 [95\% CI $0.17,3.33])$.

Misoprostolversus laminaria (Analysis 12.1; Analysis 12.2; Analysis 12.3)

When 200 or $400 \mu \mathrm{g}$ vaginal misoprostol was compared to dayprior placement of one laminaria tent, there was no difference in the need for further mechanical dilation (OR 1.04 [95\% CI 0.48, 2.26]) or length of the procedure (mean difference -0.10 [95\% CI -1.09, 0.89] [MacIsaac 1999; Burnett 2005]). Women were asked about their level of satisfaction with their cervical ripening method in both trials. In one, women reported favoring misoprostol over laminaria if they were to have a procedure in the future (RR 0.31 [95\% CI 0.12, 0.84] [Burnett 2005]); the other trial reported only that $<10 \%$ of women in both treatment groups were dissatisfied with their method of cervical dilation (MacIsaac 1999).

Misoprostol versus prostaglandin $F_{2 \alpha}$ (Analysis 13.1; Analysis 13.2; Analysis 13.3; Analysis 13.4; Analysis 13.5)

One study compared misoprostol to prostaglandin $\mathrm{F}_{2 \alpha}$ (Vimala 2005). No significant differences were noted in the need for further cervical dilation (RR $0.48[95 \% 0.16,1.41])$, rates of nausea and vomiting ( $R R 0.14$ [95\% CI 0.02, 1.23]), or the time required to complete the procedure (mean difference 0.20 [95\% CI -0.76, 1.16]). Additionally, women reported no differences in satisfaction with misoprostol or prostaglandin $\mathrm{F}_{2 \alpha}$ (RR 0.23 [95\% CI 0.04, 1.24]).

\section{Gemeprost comparisons}

Gemeprost versus Lamicel $®$ (Analysis 14.1; Analysis 14.2)

In addition to comparisons with placebo and misoprostol, gemeprost has been compared to several types of osmotic dilators. No differences in the need for further cervical dilation (RR $0.86[95 \%$ CI $0.38,1.95])$ was reported when gemeprost was compared to 
Lamicel (Golland 1989; Stornes 1991). Additionally, use of gemeprost was associated with lower rates pain during cervical preparation (RR 3.53 [95\% CI 1.40, 8.90]) when compared to Lamicel, although no significant differences were noted in rates of nausea and vomiting (RR 6.89 [95\% CI 0.83, 57.41]) during cervical preparation.

Gemeprost versus Dilapan-S ${ }^{\circledR}$ (Analysis 15.1; Analysis 15.2)

No differences in need for further dilation between those who received gemeprost or Dilapan was noted (RR 0.87 [95\% CI 0.32, 2.36]) in 2 studies (Jurgenson 1989; Golland 1989). Rates of nausea between women who received Dilapan and gemeprost were not significantly different (RR 0.83 [95\% CI 0.35, 1.95]).

Gemeprost versus laminaria (Analysis 16.1; Analysis 16.2; Analysis 16.3)

When gemeprost and laminaria were compared (WHO 1986), the need for further cervical dilation in the gemeprost group demonstrated a significant reduction when compared to placement of laminaria (RR 0.56 [95\% CI 0.29, 1.07]). Initial cervical dilation was found to be significantly greater in the gemeprost group when compared to the laminaria group (mean difference 0.50 [95\% CI $0.05,0.95]$ ). Nausea and vomiting following application of laminaria was significantly less common than with use of gemeprost (RR 18.16 [95\% CI 1.04, 318.09]).

Gemeprost versus prostaglandin $F_{2 \alpha}$ (Analysis 17.1; Analysis 17.2; Analysis 17.3)

Gemeprost was superior to prostaglandin $\mathrm{F}_{2 \alpha}$ in terms of need for further cervical dilation (RR 0.31 [95\% CI 0.15, 0.66]) and initial cervical dilation (mean difference 0.90 [95\% CI 0.42, 1.38] [WHO 1986]). No differences between groups were noted in the occurrence of nausea and vomiting (RR 1.67 [95\% CI 0.53, 5.25]).

Mifepristone comparisons: doses (Analysis 18.1; Analysis 18.2)

Doses of $100 \mathrm{mg}$ and $25 \mathrm{mg}$ mifepristone were compared in one study (WHO 1990). No significant differences between treatment groups in cervical dilation (mean difference 0.00 [95\% CI -0.74, 0.74]) or the need for futher dilation (RR 0.74 [95\% CI 0.12 , 4.62]) were demonstrated.

\section{Laminaria comparisons}

Laminaria versus prostaglandin $F_{2 \alpha}$ (Analysis 19.1; Analysis 19.2; Table 5)

One study compared the use of laminaria placed 3-4 hours prior to the procedure to that of prostaglandin $\mathrm{F}_{2 \alpha}$ (Morris 1986): these data are reported in table 5 . The study authors reported a significantly $(\mathrm{p}<0.01)$ greater effect of laminaria on initial cervical dilation when compared to prostaglandin $\mathrm{F}_{2 \alpha}$ however given the presentation of the data without standard deviations, we were unable to calculate an effect estimate. Additionally, prostaglandin $\mathrm{F}_{2 \alpha}$ was associated with more unplanned expulsions of the pregnancy prior to the procedure (RR 0.07 [95\% CI 0.00, 1.34]).

Laminaria versus sulprostone (Analysis 20.1; Analysis 20.2; Analysis 20.3)

In comparison with sulprostone, laminaria had significantly less effect on initial cervical dilation (mean difference -0.80 [95\% CI $-1.27,-0.33]$ ) as well as on the need for further dilation (RR 2.38 [95\% CI 1.26, 4.47]) (WHO, 1986). Use of sulprostone, however, had significantly higher rates of nausea and vomiting than laminaria (RR 0.02 [95\% CI 0.00, 0.39]).

Laminaria versus prostaglandin $E_{2}$. (Analysis 21.1; Analysis 21.2; Analysis 21.3)

The prostaglandin, 9 deoxo-16, 16-dimethyl-9-methylene $\mathrm{PGE}_{2}$, was compared to laminaria in one trial (WHO 1986). The effects on initial cervical dilation and need for further dilation were not significantly different, although approaching significant values in favour of a greater effect from the prostaglandin $E_{2}$. Nausea and vomiting were more common in the group receiving the prostaglandin $\mathrm{E}_{2}$ (RR 0.03 [95\% CI 0.00, 0.51]) when compared to those who received laminaria.

\section{Sulprostone comparisons}

Sulprostone dosing by intracervical administration (Analysis 22.1; Analysis 22.2; Analysis 22.3 and Table 6)

Sulprostone doses have been compared in three studies; in two (Rath 1983; Rath 1985), intracervical doses were compared and in one study, intramuscular doses were compared (Christensen 1985). For intracervical doses of either 50 or $100 \mu \mathrm{g}$ administered 6-8 hours prior to the procedure, no differences in cervical effects or in rates of nausea/ vomiting (RR 0.79 [95\% CI 0.21,3.04]) were detected. Differences were noted, however, in the occurrence of unplanned expulsion prior to the abortion procedure: significantly higher rates of unplanned expulsion occurred with the $100 \mu \mathrm{g}$ dose when compared with the $50 \mu \mathrm{g}$ dose of sulprostone (RR 0.04 [95\% CI 0.00, 0.37]).

Sulprostone dosing by intramuscular administration (Analysis 23.1; Analysis 23.2;Analysis 23.3)

When dosing by intramuscular injection was used 3-4 hours prior to the procedure, no differences in cervical effect were noted between $250 \mu \mathrm{g}$ and $500 \mu \mathrm{g}$ of sulprostone (RR 0.72 [95\% CI 0.24, 2.15]). Nausea and vomiting did differ between the doses with significantly higher rates occurring in the $500 \mu \mathrm{g}$ group (RR 0.13 [95\% CI 0.04, 0.44]). One unplanned expulsion occurred in the higher dose group, while none occurred among those who received the lower dose (RR 0.34 [95\% CI 0.01, 8.36]).

\section{$P G E_{2}$ comparisons}

Prostaglandin $E_{2}$ versus prostaglandin $F_{2 \alpha}$ (Analysis 24.1; Analysis 24.2; Analysis 24.3)

One study compared prostaglandins $\mathrm{E}_{2}$ and $\mathrm{F}_{2 \alpha}$ (Heinzl 1981). Women who received $1 \mathrm{mg}$ oral prostaglandin $\mathrm{E}_{2}$ required more mechanical cervical dilation than women receiving $2.5 \mathrm{mg}$ intracervical prostaglandin $\mathrm{F}_{2 \alpha}$ (RR 12.90 [95\% CI 7.22, 23.05]). However, they experienced less nausea (RR 0.17 [95\% CI 0.04, $0.78]$ ) and had significantly fewer unplanned expulsions prior to the procedure (RR 0.01 [95\% CI 0.00, 0.23]) than those in the prostaglandin $\mathrm{F}_{2 \alpha}$ group.

Lamicel comparisons (Analysis 25.1)

Lamicel ${ }^{\circledR}$ versus cervical tents without $\mathrm{MGSO}_{4}$ (Table 7) 
One study compared Lamicel to similar tents which did not contain $\mathrm{MgSO}_{4}$. Data reported were not complete enough for reanalysis, but initial cervical dilation between the two groups was similar. Additionally, the occurrence of unplanned expulsion prior to the procedure was similar between treatment groups (RR 3.65 [95\% CI 0.14, 94.97]).

\section{DISCUSSIO N}

The quality of evidence included in this review is mixed; however, the more recent studies are generally of good or fair quality. To improve the quality of evidence we reviewed, we excluded studies with evidence of bias, either in the methodology of randomisation or concealment of allocation. Since assessment of cervical dilation and any immediate, procedure-related complications occur at the time of the procedure, loss to follow-up in included studies did not introduce a significant source of bias. In addition, we attempted to reduce bias from our assessment and analyses of the evidence by assessing articles for inclusion in the review and extraction of data by two independant researchers.

There are many safe methods of cervical ripening prior to surgical abortion, although efficacy and side-effects between methods vary. Reports of adverse events such as cervical laceration or uterine perforation are uncommon in this body of evidence and no study has investigated whether cervical preparation impacts these rare outcomes among women having first trimester abortion procedures.

Cervical preparation decreases the length of the abortion procedure; this may become increasingly important with increasing gestational age, as mechanical dilation at later gestational ages takes longer and becomes more difficult. The decreased procedural time may have very little impact on procedures at early gestation which already take very little time to perform. These data do not suggest a gestational age where the benefits of cervical dilation outweigh the side-effects, including pain, that women experience with cervical ripening procedures or the prolongation of the time interval before procedure completion.

Few studies have evaluated women's satisfaction or perception of cervical ripening procedures. It is difficult to assess women's preferences, particularly in randomised trials where a woman experiences only one method of cervical preparation; in three of the four trials that investigated this outcome, there were no differences between treatment groups and women's disatisfaction with their cervical ripening method. In one trial, women reported higher rates of dissatisfaction with use of laminaria when compared to misoprostol.

When prostaglandins are compared, misoprostol is superior to gemeprost in terms of cervical ripening effect and in decreasing the occurrence of side-effects. Two trials demonstrated, however, a greater effect of mifepristone when compared to misoprostol, with no differences in side-effects. Misoprostol appears to be equally effective as laminaria in the studies included in this review. The dose of $400 \mu \mathrm{g}$ is superior to $200 \mu \mathrm{g}$ in terms of effects on the cervix. Routes of administration may be sublingual, which is superior to vaginal in terms of cervical effect, or vaginal, which is superior in terms of limiting side-effects.

All methods of preparation prior to the surgical procedure require 3 hours to be most efficacious, with the exception of sublingual misoprostol which may be effective at 2 hours after administration. For methods such as osmotic dilators or mifepristone, more time is needed. Particularly when prostaglandins are used, this time period of cervical preparation can be painful for women, and can be associated with gastrointestinal side-effects. Older prostaglandins, particularly at higher doses or over longer time periods, were associated with unplanned expulsion of the pregnancy prior to the surgical procedure; this appears to occur infrequently when misoprostol is administered 3 hours prior to the abortion procedure.

The conclusions of this review agree with the most recent review of cervical dilation techniques prior to 14 weeks gestation, published by the Society for Family Planning 2007 (Allen 2007). Although RCOG 2004 and WHO 2003 recommends adolescents receive cervical preparation prior to abortion procedures, no randomised trials have compared the rates of adverse outcomes of adolescents with those of adult women.

\section{AUTHORS'CONCLUSIONS}

\section{Implications for practice}

Misoprostol is the preferred prostaglandin for cervical ripening. If misoprostol is used, it should be given adequate time to have maximum effect ( 3 hours for vaginal administration, 2 hours for sublingual) without extending the time to the point where unplanned expulsions begin to occur (6-8 hours or overnight use). When adequate time elapses between administration and the surgical procedure, lower doses are as effective with lower rates of side-effects. Laminaria have a cervical ripening effect with generally lower rates of gastrointestinal side-effects and greater rates of insertional pain; their use may be limited in women who prefer a same-day procedure. Mifepristone may be superior to misoprostol in terms of cervical preparation, however, its use may be limited by its current high cost and time required for effect ( 24 hours).

\section{Implications for research}

Research should attempt to delineate the gestational age where cervical preparation decreases adverse events and whether there are groups of women where cervical preparation is particularly important (adolescents or nulliparae). Additionally, the use of mifepristone for cervical preparation in the later first trimester should be investigated. Women's preferences for cervical preparatory tech- 
niques have been inadequately explored and should be included in future research.

\section{ACKNOWLEDGEMENTS}

Regina Kulier for her German translation and Carol Manion for her assistance with the search strategy.

\section{R E F E R E N C E S}

\section{References to studies included in this review}

\section{Aronsson 2004 \{published data only\}}

Aronsson A, Helström L, Gemzell-Danielsson K. Sublingual compared with oral misoprostol for cervical dilatation prior to vacuum aspiration: a randomized comparison. Contraception 2004;69:165-9.

\section{Ashok 2000 \{published data only\}}

Premila W. Ashok, MB, Gillian M.M. Flett, BCh, Allan Templeton. MD. Mifepristone versus vaginally administered misoprostol for cervical priming before first-trimester termination of pregnancy: A randomized, controlled study. Am J Obstet Gynecol 2000;183(4): 998-1002.

Ashok 2003 \{published data only\} Ashok PW, Hamoda H, Nathani F, Flett GMM, Templeton A. Randomised controlled study comparing oral and vaginal misoprostol for cervical priming prior to surgical termination of pregnancy. BJOG 2003;110(December): 1057-61.

\section{Bokstrom 1998 \{published data only\}}

Bokström H, Atterfelt P, Alexandersson M, Brännström M, Norström A. Preoperative Cervical Softening Before First Trimester Legal Abortion by Mifepristone and Misoprostol. Contraception 1998;58:157-63.

Burnett 2005 \{published data only\} Burnett MA, Corbett CA, Gertenstein RJ. A randomized trial of laminaria tents versus vaginal misoprostol for cervical ripening in first trimester surgical abortion. J Obstet Gynaecol Can 2005;27(1):38-42.

Cakir 2005 \{published data only\}

Cakir L, Dilbaz B, Caliskan E, Dede FS, Dilbaz S, Haberal A. Comparison of oral and vaginal misoprostol for cervical ripening before manual vacuum aspiration of first trimester pregnancy under localanesthesia: a randomized placebocontrolled study. Contraception 2005;71:337-42.

Carbonell 2001 \{published data only\} Carbonell JL, Velazco AL, Rodriguez Y, Tanda R, Sánchez C, Barambio S, Valera L, Chami S, Valero F, Aragón S, Marí $\mathrm{J}$. Oral versus vaginal misoprostol for cervical priming in first-trimester abortion: a randomized trial. The European
Journal of Contraception and Reproductive Health Care 2001; 6:134-40.

Cheng 1975 \{published data only\}

Cheng MCE, Karim SMM, Ratnam SS. Peroperative cervical dilatation with 15 (S) 15 methyl prostaglandin $E_{2}$ methyl ester in first trimester nulliparae- a double-blind study. Contraception 1975;12(1):59-67.

Christensen 1984 \{published data only\} Christensen NJ, Bygdeman M. Cervical dilatation with 16, 16-dimethyl-trans-delta ${ }^{2}-\mathrm{PGE}_{1}$ methyl ester (cervagem) prior to vacuum aspiration. Contraception 1984;29(5): 457-64.

Christensen 1985 \{published data only\} Christensen NJ. Cervical dilatation with sulprostone prior to vacuum aspiration. Contraception 1985;32(4):359-65.

de Jonge 2000 \{published data only\} de Jonge ETM, Jewkes R, Levin J, Rees H. Randomised controlled trial of the efficacy of misoprostol used as a cervical ripening agent prior to termination of pregnancy in the first trimester. South African Medical Journal 2000;90 (3):256-62.

Durlot 1988 \{published data only\} Durlot F, Dubois C, Brunerie J, Frydman R. Efficacy of progesterone antangonist RU486 (mifepristone) for preoperative cervical dilatation during first trimester abortion. Human reproduction 1988;3(5):583-4.

Ekerhovd 2003 \{published data only\}

Ekerhovd E, Radulovic N, Norström A. Gemeprost versus misoprostol for cervical priming before first-trimester abortion: a randomized controlled trial. Obstetrics \& Gynecology 2003;101(4):722-5.

El-Rafaey 1994 \{published data only\} El-Rafaey H, Calder L, Wheatley DN, Templeton A. Cervical priming with prostaglandin E1 analogues, misoprostol and gemeprost. Lancet 1994;343:1207-9.

Esteve 2006 \{published data only\}

Esteve JLC, Mar|' JM, Valero F, Llorente M, Salvador I, Varela L, Leal P, Candel A, Tudela A, Serrano M, Mun oz E. Sublingual versus vaginal misoprostol $(400 \mu \mathrm{g})$ for cervical priming in first-trimester abortion: a randomized trial. Contraception 2006;74:328-333. 
Golland 1989 \{published data only\}

Golland IM, Vaughan-Williams CA, Elstein M. A comparison of osmotic dilators, Lamicel and Dilapan, and a prostaglandin $\mathrm{E}$ analogue, gemeprost, for ripening the cervix before legal abortion. Journal of Obstetrics and Gynaecology 1989;9(3):210-12.

Gupta 1990 \{published data only\}

Gupta JK, Johnson N. Effect of mifepristone on dilatation of the pregnant and non-pregnant cervix. Lancet 1990;335: $1238-40$.

Hamoda 2004 \{published data only\}

Hamoda H, Ashok PW, Flett GMM, Templeton A. A randomized controlled comparison of sublingual and vaginal administration of misoprostol for cervical priming before first-trimester surgical abortion. American Journal of Obstetrics and Gynecology 2004;190:55-9.

Heinzl 1981 \{published data only\}

Heinzl S, Andor J. Preoperative administration of prostaglandin to avoid dilatation-induced damage in firsttrimester pregnancy terminations. Gynecol Obstet Invest 1981;12(1):29-36.

Henry 1999 \{published data only\}

Henry AM, Haukkamaa M. Comparison of vaginal misoprostol and gemeprost as pre-treatment in first trimester pregnancy interruption. BJOG 1999;106:540-3.

Ho 1983 \{published data only\}

Ho PC, Liang ST, Tang GWK, Ma HK. Pre-operative cervical dilatation in termination of first trimester pregnancies using 16,16-dimethyl-trans-delta ${ }^{2} \mathrm{PGE}_{1}$ methyl ester vaginal pessaries. Contraception 1983;27(4):339-46.

Inal 2003 \{published data only\} Inal MM, Ertopçu K, Arici A, Özelmas I. The effect of oral versus vaginal misoprostol on cervical dilatation in firsttrimester abortion: a double-blind, randomized study. The European Journal of Contraception and Reproductive Health Care 2003;8(4):197-202.

Jurgenson 1989 \{published data only\}

Jürgensen U, Lasarett E, Christensen NK. Cervagem/ Dilapan for preoperative cervical dilatation prior to vacuum aspiration for termination of first trimester pregnancy. Contraception 1989;40(6):741-9.

MacIsaac 1999 \{published data only\}

MacIsaac L, Grossman D, Balistreri E, Darney P. A randomized controlled trial of laminaria, oral misoprostol, and vaginal misoprostol before abortion. Obstetrics \& Gynecology 1999;93(5):766-70.

MacKenzie 1990 \{published data only\}

MacKenzie IZ, Jackson C, McKinlay E, Millar J. Cervical priming before first trimester aspiration abortion: a single blind study comparing gemeprost $1 \mathrm{mg}$ and prostaglandin $\mathrm{E}_{2} 10 \mathrm{mg}$ pessaries. Journal of Obstetrics and Gynaecology 1990;10:513-7.

Morris 1986 \{published data only\} Morris ND, McCallum GI, Hammond L. Preoperative cervical dilatation: a trial of laminaria tents and prostaglandin $\mathrm{F}_{2 a}$ gel. The Australian \& New Zealand Journal of Obstetrics and Gynecology 1986;26(1):36-9.

Ngai 1995 \{published data only\}

Ngai SW, Tang OS, Lao T, Ho PC, Ma HK. Oral misoprostol versus placebo for cervical dilatation before vacuum aspiration in first trimester pregnancy. Human Reproduction 1995;10(5):1220-2.

Ngai 1999 \{published data only\} Ngai SW, Chan YM, Tang OS, Ho PC. The use of misoprostol prior to vacuum aspiration: a randomized trial. Human Reproduction 1999;14(8):2139-42.

Ngai, Yeung 1995 \{published data only\} Ngai SW, Yeung KCA, Lao T, Ho LC. Oral misoprostol versus vaginal gemeprost for cervical dilatation prior to vacuum aspiration in women in the sixth to twelfth week of gestation. Contraception 1995;51:347-50.

Okanlomo 1999 \{published data only\} Okanlomo KA, Ngotho D, Moodley J. Effect of misoprostol for cervical ripening prior to pregnancy interruption before twelve weeks of gestation. East African Medical Journal 1999;76(10):552-5.

Oppegaard 2004 \{published data only\} Oppegaard KS, Abdelnoor M, Nesheim BI, Jerve F, Eskild A. The use of misoprostol for pre-abortion cervical priming: a randomised controlled trial of 400 versus $200 \mu \mathrm{g}$ in first trimester pregnancies. BJOG 2004;111:154-9.

Oppegaard 2006 \{published data only\} Kevin Sunde Oppegaard, Erik Qvigstad, Britt-Ingjerd Nesheim. Oral versus self-administered vaginal misoprostol at home before surgical termination of pregnancy: a randomised controlled trial. BJOG 2006;113:58-64.

Osmers 1990 \{published data only\} Osmers R, Rath W, Conrad A, Kuhn W. A randomized double blind study of a new ready-for use prostaglandin gel (Org 2436) for cervical ripening prior to first trimester pregnancy termination. Zentralblatt für Gynäkologie 1990; 112:545-54.

Rabe 1985 \{published data only\}

T. Rabe, J. Helk, L. Kiesel, J. Zwick, B. Runnebaum. Use of a new vaginal suppository: prostaglandin $\mathrm{E}_{1}$ analog Gemeprost for cervix maturation prior to abortion in the 1st trimester [Anwendung eines neuen Scheidenzäpfchens: Prostaglandin- $\mathrm{E}_{1}-$ Analog Gemeprost zur Zervixreifung vor Schwangerschaftsabbrüchen im ersten Trimester]. Geburtshilfe und Frauenheilkunde 1985;45(6):393-401.

Radestad 1988 \{published data only\}

Rådestad A, Christensen NJ, Strömberg L. Induced cervical ripening with mifepristone in first trimester abortion. Contraception 1988;38(3):301-12.

Radestad 1989 \{published data only\} Arne Rådestad, Niels J. Christensen. Magnesium sulphate and cervical ripening (a biomechanical doubleblind, randomized comparison between a synthetic polyvinyl sponge with and without magnesium sulphate). Contraception 1989;39(3):253-63. 
Rath 1983 \{published data only\}

Rath W, Meyer D, Hildebrandt J, Hilgers R, Kuhn W. Comparative study of various intracervically administered PG gel preparations for termination of first trimester pregnancies. Contraception 1983;28(3):209-22.

Rath 1985 \{published data only\}

Rath W, Dennemark N, Gödicke HD. Preoperative cervical priming by intracervical application of a new sulprostone gel. Contraception 1985;31(3):207-16.

Shalev 1988 \{published data only\}

Shalev E, Tsabari A, Edelstein S, Weiner E, Zuckerman $\mathrm{H}$. Intracervical administration of prostaglandin E2-gel prior to therapeutic abortion: a prospective randomized double-blind study. International Journal of Gynaecology and Obstetrics 1988;27(1):119-22.

Sharma 2005 \{published data only\}

Sharma S, el Refaey H, Stafford M, Purkayastha S, Parry M, Axby $\mathrm{H}$. Oral versus vaginal misoprostol administered one hour beforesurgical termination of pregnancy: a randomised controlled trial. BJOG 2005;112:456-60.

Singh 1998 \{published data only\}

Singh K, Fong KF, Prasad RN, Dong F. Randomized trial to determine optimal dose of vaginal misoprostol for preabortion cervical priming. Obstetrics \& Gynecology 1998; 92(5):795-8.

Singh 1999 \{published data only\}

Singh K, Fong YF, Prasad RN, Dong F. Vaginal misoprostol for pre-abortion cervical priming:is there an optimal evacuation time interval?. BJOG 1999;106:266-9.

Singh, Fong 1999 \{published data only\} Singh K, Fong YF, Prasad RNV, Dong F. Evacuation interval after vaginal misoprostol for preabortion cervical priming: a randomized trial. Obstetrics \& Gynecology 1999;94(3): $431-4$.

Stornes 1991 \{published data only\}

I. Stornes, K.L. Rasmussen. A comparison of Lamicel tents and gemeprost (Cervagem) pessaries prior to first trimester abortion. Achives of Gynecology and Obstetrics 1991;249(2): $67-72$.

Tang 2004 \{published data only\}

Tang OS, Mok KH, Ho PC. A randomized study comparing the use of sublingual to vaginal misoprostol for pre-operative cervical priming prior to surgical termination of pregnancy in the first trimester. Human Reproduction 2004;19(5): $1101-4$.

Vimala 2003 \{published data only\} Vimala N, Mittal S, Kumar S. Sublingual misoprostol for preabortion cervical ripening in first-trimester pregnancy termination. Contraception 2003;67:295-7.

Vimala 2004 \{published data only\}

Vimala N, Mittal S, Kumar S, Dadhwal V, Sharma Y.

A randomized comparison of sublingual and vaginal misoprostol for cervical priming before suction termination of first-trimester pregnancy. Contraception 2004;70:117-20.
Vimala 2005 \{published data only\}

Vimala N, Mittal S, Dadhwal V. Cervical priming with sublingual misoprostol vs.15-methyl-prostaglandin F2A prior to surgical abortion. Contraception 2005;88:134-7.

Vimala, Mittal 2004 \{published data only\}

Vimala N, Mittal S, Dadhwal V. Sublingual misoprostol before first trimester abortion: a comparative study using two dose regimens. Indian Journal of Medical Sciences 2004; 58(2):54-61.

Wang 1989 \{published data only\}

Wang YF, Jin YC, Wu YE, Gu LJ, Xie XH. The cervix ripening effect of 15-methyl-prostaglandin F2A methyl ester before vacuum aspiration for termination of early pregnancy in primigravidae. Chinese Medical Journal 1989; 102(3):200-2.

WHO 1986 \{published data only\}

Krishna U, Gupta AN, Ma HK, Manuilova I, Hingorani V, Prasad RN, Bygdeman M, Herczeg J, ObersnelKveder D, Losa A, et al.Randomized comparison of different prostaglandin analogues and laminaria tent for preoperative cervical dilatation. World Health Organization Special Programme of Research, Development and Research Training in Human Reproduction: Task Force on Prostaglandins for Fertility Regulation. Contraception 1986; 34(3):237-51.

\section{WHO 1990 \{published data only\}}

World Health Organization. Task Force on Post-ovulatory Methods for Fertility Regulation. The use of mifepristone (RU 486) for cervical preparation in first trimester pregnancy termination by vacuum aspiration. BJOG 1990; 97(3):260-6.

Wiebe 1998 \{published data only\}

Wiebe ER, Rawling MJ. Vaginal misoprostol before first trimester abortion. International Journal of Gynecology \& Obstetrics 1998;60:175-6.

\section{References to studies excluded from this review}

\section{Bryman 1988 \{published data only\}}

Bryman I, Granberg S, Norström A. Reduced incidence of postoperative endometritis by the use of Laminaria tents in connection with first trimester abortion. Acta Obstet Gynecol Scand 1988;67(4):323-5.

Frankman 1980 \{published data only\} Frankman O, Bygdeman M, Gréen K, Moberg P, Sandberg CG. Dilatation of the cervix prior to vacuum aspiration by single vaginal administration of 15-methyl-PGF2 alpha methyl ester. Contraception 1980;21(6):571-6.

Heinzl 1987 \{published data only\} Heinzl S, Hendry M. Sulprostone (Nalador) versus gemeprost (Cervagem) for cervical priming in the termination of pregnancy during the first trimester. Contraception 1987;35(3):271-82. 
Hulka 1987 \{published data only\}

Hulka JF, Chepko M. Vaginal prostaglandin $\mathrm{E}_{1}$ analogue to soften the cervix in first trimester abortion. Obstetrics \& Gynecology 1987;69(1):57-60.

Ivy Li 2003 \{published data only\} Ivy Li CF, Carina Chan CW, Ho PC. A comparison of isosorbide mononitrate and misoprostol cervical ripening before suction evacuation. Obstetrics \& Gynecology 2003; 102(3): $583-8$

\section{Khanna 1980 \{published data only\}}

Khanna NM, Sarin JPS, Nandi RC, Singh S, Setty BS, Kamboj VP, Dhawan BN. Isaptent-- A new cervical dilator. Contraception 1980;21(1):29-40.

Platz-Christensen \{published data only\}

Platz-Christensen JJ, Nielsen S, Hamgerger L. Is misoprostol the drug of choice for induced cervical ripening in early pregnancy termination?. Acta Obstetricia et Gynecologica Scandinavica 1995;74:809-12.

Saxena 2004 \{published data only\}

Saxena P, Salhan S, Sarda N. Comparison between the sublingual and oral route of misoprostol for pre-abortion cervical priming in first trimester abortions. Human Reproduction 2004;19(1):77-80.

Saxena 2006 \{published data only\}

Saxena P, Salhan S, Sarda N. Sublingual versus vaginal route of misoprostol for cervical ripening prior to surgical termination of first trimester abortions. European Journal of Obstetrics \& Gynecology and Reproductive Biology 2006;125: 109-13.

Skjeldestad 1990 \{published data only\}

Skjeldestad FE, Tuveng J. Cervical dilatation with Lamical in first trimester therapeutic abortion. International Journal of Gynecology and Obstetrics 1990;33:153-7.

Vengadasalam 1981 \{published data only\}

Vengadasalam D, Chow KK. Use of laminaria tent in the termination of first trimester pregnancy- A controlled study. Singapore Journal of Obstetrics and Gynaecology 1981;12(1): 35-9.

\section{References to ongoing studies}

von Hertzen \{published data only\}

Pretreatment with misoprostol before vacuum aspiration for first trimester induced abortion. Ongoing study 2002.

\section{Additional references}

Allen 2007

Allen RH, Goldberg AB, Board of Society of Family Planning. Cervical dilation before first trimester surgical abortion ( $<14$ weeks gestation). SFP Guideline 20071. Contraception 2007;76(1):139-56.

Cates 1983

Cates W, Schulz K, Grimes DA. The risks associated with teenage abortion. New England Journal of Medicine 1983; 309:621-4

Hakim-Elahi 1990

Hakim-Elahi E, Tovell HM, Burnhill MS. Complications of first-trimester abortion: a report of 170,000 cases. Obstetrics \& Gynecolology 1990;76:129-35.

\section{Khanna 1980}

Khanna NM, Sarin JP, Nandi RC, Singh S, Setty BS, Kamboj VP, et al.Isaptent--a new cervical dilator. Contraception 1980;21:29-40.

\section{Kulier 2001}

Kulier R, Fekih A, Hofmeyr GJ, Campana A. Surgical methods for first trimester termination of pregnancy. Cochrane Database of Systematic Reviews 2001, Issue 4. Art.No.: CD002900. [DOI: 11687167; : ; : ; : ; : ; PUBMED: 11687167]

\section{Manabe 1981}

Manabe Y, Manabe A. Nelaton catheter for gradual and safe cervical dilatation: an ideal substitute for laminaria. $A m J$ Obstet Gynecol 1981;140:465-6.

Ng 1973

$\mathrm{Ng}$ AY. Use of the vibrodilator in outpatient termination of pregnancy. Aust NZJ Obstet Gynaecol 1973;13:228-30.

\section{RCOG 1985}

Royal College of General Practitioners, Royal College of Obstetricians and Gynaecologists. Induced abortion operations and their early sequelae. JR Coll Gen Pract 1985; 35: $175-80$

\section{RCOG 2004}

Royal College of Obstetricians and Gynaecologists. The care of women requesting induced abortion. Royal College of Obstetricians and Gynaecologists (RCOG) Evidencebased Clinical Guideline 2004, issue No. 7.

WHO 2003

World Health Organization. Safe Abortion: Technical and Policy Guidance for Health Systems. World Health Organization, Geneva 2003.

* Indicates the major publication for the study 


\section{CHARACTERISTICS OF STUDIES}

\section{Characteristics of included studies [ordered by study ID]}

\section{Aronsson 2004}

\begin{tabular}{|c|c|c|}
\hline Methods & \multicolumn{2}{|c|}{ Randomisation method not described. Allocation using sealed, sequentially numbered envelopes } \\
\hline Participants & \multicolumn{2}{|c|}{$\begin{array}{l}32 \text { women } \\
\text { Included: women between } 8 \text { and } 12 \text { weeks of pregnancy. Exclusion criteria: prior delivery/abortion, } \\
\text { abnormal pregancy, contraindication to misoprostol, signs of genital infection } \\
\text { Hospital setting, Sweden. }\end{array}$} \\
\hline Interventions & \multicolumn{2}{|c|}{$\begin{array}{l}\text { Intervention 1: } 400 \mu \mathrm{g} \text { misoprostol administered orally } 3 \mathrm{~h} \text { prior to surgery } \\
\text { Intervention 2: } 400 \mu \mathrm{g} \text { misoprostol administered sublingually } 3 \mathrm{~h} \text { prior to surgery }\end{array}$} \\
\hline Outcomes & \multicolumn{2}{|c|}{ Pre-operative cervical dilation, blood loss } \\
\hline Notes & \multicolumn{2}{|c|}{$\begin{array}{l}\text { Sealed envelopes did not stipulate that they were opaque. Attempted to clarify randomisation and allocation } \\
\text { with author but received no response }\end{array}$} \\
\hline \multicolumn{3}{|l|}{ Risk of bias } \\
\hline Item & Authors' judgement & Description \\
\hline Allocation concealment? & Unclear & B- unclear \\
\hline
\end{tabular}

Ashok 2000

\begin{tabular}{ll} 
Methods & $\begin{array}{l}\text { Randomisation using sequentially numbered, sealed, opaque envelopes that had been prepared using a } \\
\text { random number table }\end{array}$ \\
\hline Participants & $\begin{array}{l}90 \text { women. } \\
\text { Included: women who underwent vacuum aspiration abortion, } 15-40 \text { years old, between } 6.6 \text { and } 12 . \\
1 \text { weeks gestation age, with no contraindications to prostaglandin or mifepristone. Exculsion criteria: } \\
\text { symptoms or signs of a threatened miscariage, history of cervical surgery, or women living } \geq 1 \text { hour away } \\
\text { from the hospital } \\
\text { Hospital setting, Scotland. }\end{array}$ \\
\hline
\end{tabular}

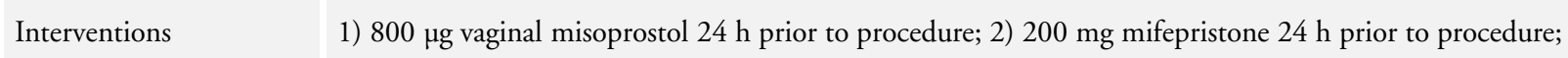
3) $200 \mathrm{mg}$ mifepristone $48 \mathrm{~h}$ prior to procedure

Outcomes Initial cervical dilation, need for further dilation, force needed for dilation, blood loss, acceptibility

Notes

Risk of bias

\begin{tabular}{|c|c|c|c|}
\hline Item & Authors' judgement & Description & \\
\hline
\end{tabular}


Ashok 2000 (Continued)

\begin{tabular}{l|l|l}
\hline Allocation concealment? & Yes & A-Adequate \\
\hline
\end{tabular}

\begin{tabular}{|c|c|c|}
\hline Methods & \multicolumn{2}{|c|}{$\begin{array}{l}\text { Randomisation by random number tables and allocation by sequentially numbered, opaque, sealed en- } \\
\text { velopes }\end{array}$} \\
\hline Participants & \multicolumn{2}{|c|}{$\begin{array}{l}64 \text { women } \\
\text { Included: women in in their first pregnancy over } 16 \text { years, singleton viable intrauterine pregnancy at } \\
\text { gestations up to } 91 \text { days, no contraindication to prostaglandins. Exclusion criteria: threatened miscarriage } \\
\text { or hemorrhagic disorders } \\
\text { Hospital setting, Scotland. }\end{array}$} \\
\hline Interventions & \multicolumn{2}{|c|}{$\begin{array}{l}\text { 1) misoprostol } 400 \mu \mathrm{g} \text { orally at home; 2) Two tablets of misoprostol } 400 \mu \mathrm{g} \text { vaginally in the hospital 2- } \\
\text { 4hours pre-operative }\end{array}$} \\
\hline Outcomes & \multicolumn{2}{|c|}{ Efficacy (initial dilation and force needed), side-effects, acceptability } \\
\hline Notes & \multicolumn{2}{|c|}{ No cervical lacerations or perforations occurred. } \\
\hline \multicolumn{3}{|l|}{ Risk of bias } \\
\hline Item & Authors' judgement & Description \\
\hline Allocation concealment? & Yes & A-Adequate \\
\hline
\end{tabular}

\section{Bokstrom 1998}

\begin{tabular}{|c|c|c|}
\hline Methods & \multicolumn{2}{|c|}{ Randomised in a double-blinded manner (not otherwise specified) } \\
\hline Participants & \multicolumn{2}{|c|}{$\begin{array}{l}45 \text { women. } \\
\text { Included: nulliparae between } 8 \text { to }<10 \text { weeks gestation. Gestational age confirmed by ultrasound } \\
\text { Hospital setting, Sweden }\end{array}$} \\
\hline Interventions & \multicolumn{2}{|c|}{$\begin{array}{l}\text { Treated with 1) misoprostol orally ( } 600 \mu \mathrm{gg}) 16 \text { to } 20 \mathrm{~h} \text { before surgery } 2) \\
\text { mifepristone }(200 \mathrm{mg}) 48 \text { and } 24 \mathrm{~h} \text { before surgery or } 3) \text { placebo }\end{array}$} \\
\hline Outcomes & \multicolumn{2}{|c|}{ Side effects and pain, degree of cervical dilation, immunohistochemistry } \\
\hline Notes & \multicolumn{2}{|c|}{ Attempted to clarify randomisation and allocation with author but received no response } \\
\hline \multicolumn{3}{|l|}{ Risk of bias } \\
\hline Item & Authors' judgement & Description \\
\hline Allocation concealment? & Unclear & B-Unclear \\
\hline
\end{tabular}


Burnett 2005

\begin{tabular}{|c|c|c|}
\hline Methods & \multicolumn{2}{|c|}{ Randomisation by coin toss. Open-label. } \\
\hline Participants & \multicolumn{2}{|c|}{$\begin{array}{l}70 \text { women. } \\
\text { Included: healthy women }<15 \text { weeks gestation. Exclusion criteria: not stated } \\
\text { Canada, unclear setting }\end{array}$} \\
\hline Interventions & \multicolumn{2}{|c|}{ 1) misorpostol $200 \mu \mathrm{g}$ vaginally; 2) Laminaria tents } \\
\hline Outcomes & \multicolumn{2}{|l|}{ Degree of dilation } \\
\hline \multicolumn{3}{|l|}{ Notes } \\
\hline \multicolumn{3}{|l|}{ Risk of bias } \\
\hline Item & Authors' judgement & Description \\
\hline Allocation concealment? & Unclear & B-Unclear \\
\hline
\end{tabular}

Cakir 2005

\begin{tabular}{|c|c|c|}
\hline Methods & \multicolumn{2}{|c|}{$\begin{array}{l}\text { Computer-based restricted stratified randomisation was generated, and sealed envelopes were used for } \\
\text { allocation concealment. Placebo-controlled trial }\end{array}$} \\
\hline Participants & \multicolumn{2}{|c|}{$\begin{array}{l}160 \text { women randomised. } \\
\text { Included: women at } 7-10 \text { weeks gestation with singleton pregnancy. Exclusion criteria: systemic disease, } \\
\text { contraindication for misoprostol, history cervical surgery (major or minor), threatened or missed abor- } \\
\text { tion or initialinitial cervical dilation, } \mathrm{Hgb}<10 \text {, bleeding or spotting during current pregnancy, multiple } \\
\text { pregnancy, basal cervical dilation greater than } 4 \mathrm{~mm} \text {. Confirmed gestational age by US } \\
\text { Family planning clinic, Turkey. }\end{array}$} \\
\hline Interventions & \multicolumn{2}{|c|}{$\begin{array}{l}\text { Three hours prior to procedure: 1) oral placebo 2) vaginal placebo 3) oral misoprostol } 400 \mu \mathrm{g} 4 \text { ) vaginal } \\
\text { misoprostol } 400 \mu \mathrm{g}\end{array}$} \\
\hline Outcomes & \multicolumn{2}{|c|}{ Side effects, blood loss, degree of cervical dilation } \\
\hline Notes & \multicolumn{2}{|c|}{$\begin{array}{l}\text { Sealed envelopes did not stipulate that they were opaque or sequentially numbered } \\
\text { Reported no unplanned expulsions of the pregnancy before scheduled procedure and no hospitalizations } \\
\text { for complications } \\
\text { Two women who received oral misoprostol developed fevers. }\end{array}$} \\
\hline \multicolumn{3}{|l|}{ Risk of bias } \\
\hline Item & Authors' judgement & Description \\
\hline Allocation concealment? & Unclear & B- unclear \\
\hline
\end{tabular}


Methods Randomisation method not specified. Allocation using sealed, opaque, sequential envelopes

\begin{tabular}{|c|c|c|}
\hline Participants & \multicolumn{2}{|c|}{$\begin{array}{l}900 \text { women. } \\
\text { Included: women at least } 18 \text { years of age, gestational age up to } 63 \text { days, ability of the woman to give } \\
\text { informed consent, to understand and complete the protocol, and willingness to abstain from sexual } \\
\text { intercourse for the first } 14 \text { days of the study. Exclusion criteria: Hgb }<10 \text {, HTN, threatened/ ongoing } \\
\text { abortion, contraindication to misoprostol, active gential infection. Confirmed gestational age by US } \\
\text { Maternity hospital, Cuba. }\end{array}$} \\
\hline Interventions & \multicolumn{2}{|c|}{$400 \mu \mathrm{g}$ misoprostol administrered 1 ) orally $8 \mathrm{~h}$ prior 2 ) vaginally $4 \mathrm{~h}$ prior } \\
\hline Outcomes & \multicolumn{2}{|c|}{ Cervical dilation, side-effects, blood loss } \\
\hline Notes & \multicolumn{2}{|c|}{$\begin{array}{l}2 \text { women who received oral misoprostol had unplanned expulsions prior to the procedure } \\
\text { No cervical lacerations or perforations occurred. }\end{array}$} \\
\hline \multicolumn{3}{|l|}{ Risk of bias } \\
\hline Item & Authors' judgement & Description \\
\hline Allocation concealment? & Yes & A-Adequate \\
\hline
\end{tabular}

Cheng 1975

\begin{tabular}{|c|c|c|}
\hline Methods & \multicolumn{2}{|c|}{ Double-blinded randomised controlled trial (method not specified) } \\
\hline Participants & \multicolumn{2}{|c|}{$\begin{array}{l}50 \text { women. } \\
\text { Included: women aged } 15-29 \text { with gestational ages } 7-12 \text { weeks and who were nulliparous } \\
\text { Hospital setting, Singapore }\end{array}$} \\
\hline Interventions & \multicolumn{2}{|c|}{$\begin{array}{l}\text { Twenty hours before procedure: 1) } 25 \mu \mathrm{g} 15 \text { methyl PGE2 methyl ester administered extra-amniotically } \\
\text { 2) } 2 \mathrm{ml} \text { normal saline }\end{array}$} \\
\hline Outcomes & \multicolumn{2}{|c|}{ Side effects, cervical dilation } \\
\hline Notes & \multicolumn{2}{|c|}{$\begin{array}{l}\text { Attempted to clarify randomisation and allocation with author but received no response. There were } 3 \\
\text { cervical lacerations in the placebo group }\end{array}$} \\
\hline \multicolumn{3}{|l|}{ Risk of bias } \\
\hline Item & Authors' judgement & Description \\
\hline Allocation concealment? & Unclear & B- Unclear \\
\hline
\end{tabular}




\begin{tabular}{|c|c|c|c|}
\hline Methods & \multicolumn{3}{|c|}{ Randomised controlled trial (not otherwise specified). } \\
\hline Participants & \multicolumn{3}{|c|}{$\begin{array}{l}134 \text { women randomised. Mean gestation 69-71 (51-119) days. Included nulliparous healthy women, } \\
\text { gestational age }<13 \text { weeks, no signs of threatened abortion } \\
\text { Hospital setting, Sweden }\end{array}$} \\
\hline Interventions & \multicolumn{3}{|c|}{$\begin{array}{l}3 \text { hours prior to procedure, women received either 1)16,16-dimethyl-trans-delta2- PGE1 methyl ester 2) } \\
\text { placebo }\end{array}$} \\
\hline Outcomes & \multicolumn{3}{|c|}{ Cervical dilation, further dilation needed, blood loss } \\
\hline Notes & \multicolumn{3}{|c|}{$\begin{array}{l}\text { Attempted to clarify randomisation and allocation with author but received no response. No cervical } \\
\text { lacerations occurred. Two uterine perforations occurred in the placebo group }\end{array}$} \\
\hline \multicolumn{4}{|l|}{ Risk of bias } \\
\hline Item & \multicolumn{2}{|l|}{ Authors' judgement } & Description \\
\hline Allocation concealment? & \multicolumn{2}{|l|}{ Unclear } & B- Unclear \\
\hline \multicolumn{4}{|l|}{ Christensen 1985} \\
\hline Methods & \multicolumn{3}{|c|}{ Randomised controlled trial } \\
\hline Participants & \multicolumn{3}{|c|}{$\begin{array}{l}200 \text { women. } \\
\text { Included: women in } 8-12 \text { th week pregnancy with average age } 22-23 \text { years and average gestational age } 10 \\
\text { weeks } \\
\text { Hospital setting, Sweden }\end{array}$} \\
\hline Interventions & \multicolumn{3}{|c|}{ 3-4 h before procedure intramuscular sulprostone 1) $250 \mu \mathrm{g}$ 2) $500 \mu \mathrm{g}$} \\
\hline Outcomes & \multicolumn{3}{|c|}{ Side-effects, cervical dilation } \\
\hline Notes & \multicolumn{3}{|c|}{$\begin{array}{l}\text { Attempted to clarify randomisation and allocation with author but received no response. No cervical } \\
\text { lacerations occurred. One uterine perforation occurred in the } 500 \mu \mathrm{g} \text { group }\end{array}$} \\
\hline \multicolumn{4}{|l|}{ Risk of bias } \\
\hline Item & Authors' judgement & Description & \\
\hline Allocation concealment? & Unclear & B- Unclear & \\
\hline
\end{tabular}


de Jonge 2000

Methods Double-blind, randomised (using permuted size 8 blocks for the first 152 women but not for the following 118) placebo-controlled trial

\begin{tabular}{ll} 
Participants & $\begin{array}{l}278 \text { women randomised. } \\
\text { Included: gestational age }<13 \text { weeks (average gestational age of } 62 \text { days, average age 27-28). Exclusion } \\
\text { criteria: symptomatic asthma/cardiac disease, anticoagulant therapy or Hgb }<8, \text { other serious medical } \\
\text { conditions. Gestational age confirmed by US } \\
\text { Hospital setting, South Africa. }\end{array}$ \\
\hline Interventions & $2-3$ hours prior to procedure: 1$) 600 \mu$ misoprostol vaginally or 2$)$ placebo (750 mg ascorbic acid) \\
\hline Outcomes & Degree of cervical dilation \\
\hline Notes &
\end{tabular}

\section{Risk of bias}

\begin{tabular}{l|ll}
\hline Item & Authors' judgement & Description \\
\hline Allocation concealment? & Yes & A-Adequate \\
\hline
\end{tabular}

Durlot 1988

\begin{tabular}{|c|c|c|}
\hline Methods & \multicolumn{2}{|c|}{$\begin{array}{l}\text { Double-blinded randomised controlled trial (methods not specified) using a non-algorithmic randomisa- } \\
\text { tion method, per study authors. This method was not further described }\end{array}$} \\
\hline Participants & \multicolumn{2}{|c|}{$\begin{array}{l}64 \text { women randomised. } \\
\text { Included women between } 6-12 \text { weeks gestation. Exclusion criteria: women with liver, GI or renal disease } \\
\text { or having received corticosteriods last } 3 \text { month } \\
\text { Hospital setting, France }\end{array}$} \\
\hline Interventions & \multicolumn{2}{|c|}{2 days prior to procedure women received: 1) placebo 2) mifepristone $200 \mathrm{mg} /$ day } \\
\hline Outcomes & \multicolumn{2}{|l|}{ Cervical dilation } \\
\hline \multicolumn{3}{|l|}{ Notes } \\
\hline \multicolumn{3}{|l|}{ Risk of bias } \\
\hline Item & Authors' judgement & Description \\
\hline Allocation concealment? & Yes & A- Adequate \\
\hline
\end{tabular}


Ekerhovd 2003

\begin{tabular}{|c|c|}
\hline Methods & Randomisation by sealed, opaque sequential envelopes prepared using random number tables \\
\hline Participants & $\begin{array}{l}90 \text { women randomised. } \\
\text { Included women who were healthy and nulliparous with singleton pregnancy, 8-12 weeks' gestation. Ex- } \\
\text { cluded women with threatened abortion or any kind of chronic disease (requiring daily meds). Confirmed } \\
\text { dating by US } \\
\text { Hospital setting, Sweden }\end{array}$ \\
\hline Interventions & 3-4 h prior to procedure, women receieved either: 1) $1 \mathrm{mg}$ gemeprost or 2) $400 \mu \mathrm{g}$ misoprostol \\
\hline Outcomes & Cervical dilation and peak force to dilate \\
\hline Notes & No cervical lacerations or uterine perforations occurred. \\
\hline \multicolumn{2}{|l|}{ Risk of bias } \\
\hline Item & Authors' judgement \\
\hline Allocation concealment? & A-Adequate \\
\hline \multicolumn{2}{|l|}{ El-Rafaey 1994} \\
\hline Methods & Randomisation using computer-generated random number tables. \\
\hline Participants & $\begin{array}{l}90 \text { women randomised. } \\
\text { Included: nulliparous women with pregnancies between 9-13 weeks. Excluded: women with history of } \\
\text { cervical surgery or threated abortion } \\
\text { Hospital setting, Scotland }\end{array}$ \\
\hline Interventions & $2-4 \mathrm{~h}$ prior to procedure women received vaginally: 1) gemeprost $1 \mathrm{mg}$ 2) misoprostol $600 \mu \mathrm{g}$ or 3) placebo \\
\hline Outcomes & Side-effects, cervical dilation, blood loss, biopsy specimens \\
\hline Notes & $\begin{array}{l}\text { One cervical laceration and one hospitalization occurred in the placebo group. No uterine perforations } \\
\text { occurred }\end{array}$ \\
\hline \multicolumn{2}{|l|}{ Risk of bias } \\
\hline Item & Authors' judgement \\
\hline Allocation concealment? & B- Unclear \\
\hline
\end{tabular}


Esteve 2006

\begin{tabular}{|c|c|c|}
\hline Methods & \multicolumn{2}{|c|}{ Computer-generated randomisation with allocation using sealed, opaque sequential envelopes } \\
\hline Participants & \multicolumn{2}{|c|}{$\begin{array}{l}1424 \text { women randomised. } \\
\text { Average gestation } 55 \text { days. Included: healthy women no more than } 84 \text { days gestation, willingness to abstain } \\
\text { from sex for } 14 \text { days after abortion, and ability to give informed consent. Exclusion for } \mathrm{Hgb}<10 \text {, HTN } \\
(\geq 160-90) \text {, threatened abortion (prior uterine bleeding), active genital infection, suspected ectopic, or } \\
\text { intolerance to misoprostol. Gestational age confirmed by US } \\
\text { Clinics in Spain. }\end{array}$} \\
\hline Interventions & \multicolumn{2}{|c|}{ Misoprostol $400 \mu \mathrm{g} 1-3 \mathrm{~h}$ before procedure, administered 1) sublingually 2) vaginally } \\
\hline Outcomes & \multicolumn{2}{|c|}{ Cervical dilation, side-effects, length of procedure } \\
\hline Notes & \multicolumn{2}{|c|}{ No cervical lacerations or uterine perforations occurred. One hospitalization occurred } \\
\hline \multicolumn{3}{|l|}{ Risk of bias } \\
\hline Item & Authors' judgement & Description \\
\hline Allocation concealment? & Yes & A- Adequate \\
\hline \multicolumn{3}{|l|}{ Golland 1989} \\
\hline Methods & \multicolumn{2}{|c|}{ Randomised by random number generation. } \\
\hline Participants & \multicolumn{2}{|c|}{$\begin{array}{l}66 \text { women randomised. } \\
\text { Included nulliparous women between } 7-14 \text { weeks gestation aged } 16-28 \text { years. Excluded those with a } \\
\text { history of cervical surgery } \\
\text { Hospital setting, UK }\end{array}$} \\
\hline Interventions & \multicolumn{2}{|c|}{3 hour prior to procedure women received: 1) gemeprost $1 \mathrm{mg}$ 2) $3 \mathrm{~mm}$ Lamicel dilator 3) $4 \mathrm{~mm}$ Dilapan } \\
\hline Outcomes & \multicolumn{2}{|c|}{ Degree of cervical dilation } \\
\hline Notes & \multicolumn{2}{|c|}{$\begin{array}{l}\text { Surgeon blinded to treatment group. Two cervical lacerations occurred. There were no uterine perforations, } \\
\text { hospitalizations or infections }\end{array}$} \\
\hline \multicolumn{3}{|l|}{ Risk of bias } \\
\hline Item & Authors' judgement & Description \\
\hline Allocation concealment? & Unclear & B- unclear \\
\hline
\end{tabular}




\section{Gupta 1990}

\begin{tabular}{|c|c|c|}
\hline Methods & \multicolumn{2}{|c|}{ Randomised, placebo-controlled study using a stratified randomisation code } \\
\hline Participants & \multicolumn{2}{|c|}{$\begin{array}{l}30 \text { women randomised. } \\
\text { Included: women up to } 91 \text { days gestation aged 18-39. Excluded: women with multiple gestations, ec- } \\
\text { topic pregancy, missed abortion, threatened abortion, previous cervical surgery, serious medical illness, or } \\
\text { treatment with steriods in last } 6 \text { months } \\
\text { Hospital setting, UK. }\end{array}$} \\
\hline Interventions & \multicolumn{2}{|c|}{ 42-53 h before procedure, women received: 1) placebo or 2) mifepristone $600 \mathrm{mg}$ orally } \\
\hline Outcomes & \multicolumn{2}{|c|}{ Cervical dilation, blood loss } \\
\hline Notes & \multicolumn{2}{|c|}{ A third party held the allocation code. } \\
\hline \multicolumn{3}{|l|}{ Risk of bias } \\
\hline Item & Authors' judgement & Description \\
\hline Allocation concealment? & Unclear & B- unclear \\
\hline \multicolumn{3}{|l|}{ Hamoda 2004} \\
\hline Methods & \multicolumn{2}{|c|}{ Randomised by sequential, opaque sealed envelopes generated by random number tables } \\
\hline Participants & \multicolumn{2}{|c|}{$\begin{array}{l}74 \text { women were randomised. } \\
\text { Included: women who were nulliparous, with singleton pregnancy in first trimester. Excluded: women } \\
\text { with previous cervical surgery, contraindication to misoprostol, or a previous pregnancy. Gestational age } \\
\text { confirmed by US } \\
\text { Hospital setting, Scotland. }\end{array}$} \\
\hline Interventions & \multicolumn{2}{|c|}{$2-4 \mathrm{~h}$ prior to surgery, women received misoprostol $400 \mu \mathrm{g}$ either: 1) sublingually or 2) vaginally } \\
\hline Outcomes & \multicolumn{2}{|c|}{ Bleeding, side-effects, cervical dilation } \\
\hline Notes & \multicolumn{2}{|c|}{ No cervical lacerations, uterine perforations, hospitalizations or infections occurred } \\
\hline \multicolumn{3}{|l|}{ Risk of bias } \\
\hline Item & Authors' judgement & Description \\
\hline Allocation concealment? & Yes & A-adequate \\
\hline
\end{tabular}


Heinzl 1981

\begin{tabular}{|c|c|c|}
\hline Methods & \multicolumn{2}{|c|}{ Randomisation using a random number table. The trial was double-blinded } \\
\hline Participants & \multicolumn{2}{|c|}{$\begin{array}{l}581 \text { women randomised. } \\
\text { The average gestation was between 9-10 weeks. Included women up to } 12 \text { weeks ( } 7-12 \text { weeks) gestation } \\
\text { Hospital setting, Switzerland. }\end{array}$} \\
\hline Interventions & \multicolumn{2}{|c|}{$\begin{array}{l}\text { Administered approximately } 16 \text { h prior: 1) } 1 \mathrm{mg} \text { prostaglandin E2 orally 2) } 2.5 \mathrm{mg} \text { prostglandin F2 alpha } \\
\text { intracervically 3) placebo intracervical gel or } 4 \text { ) nothing }\end{array}$} \\
\hline Outcomes & \multicolumn{2}{|l|}{ Cervical dilation } \\
\hline Notes & \multicolumn{2}{|c|}{$\begin{array}{l}\text { Author contacted to provide the methods of randomisation and allocation } \\
\text { No uterine perforations occurred. Two infections (one each in the oral PGE group and placebo group) } \\
\text { and } 1 \text { hospitalization (oral PGE group) occurred }\end{array}$} \\
\hline \multicolumn{3}{|l|}{ Risk of bias } \\
\hline Item & Authors' judgement & Description \\
\hline Allocation concealment? & Unclear & B- Unclear \\
\hline \multicolumn{3}{|l|}{ Henry 1999} \\
\hline Methods & \multicolumn{2}{|c|}{$\begin{array}{l}\text { Randomisation generated by random number tables (with block size of 20) and allocated using sealed } \\
\text { envelopes }\end{array}$} \\
\hline Participants & \multicolumn{2}{|c|}{$\begin{array}{l}199 \text { women randomised. } \\
\text { Included: women aged } 18-44 \text { years with mean gestational age of } 9.7 \text { weeks } \\
\text { Maternity hospital, Finland. }\end{array}$} \\
\hline Interventions & \multicolumn{2}{|c|}{ Women received: 1) $200 \mu \mathrm{g}$ vaginal misoprostol; 2) gemeprost $1 \mathrm{mg}$ vaginal } \\
\hline Outcomes & \multicolumn{2}{|c|}{ Cervical dilation, blood loss } \\
\hline Notes & \multicolumn{2}{|c|}{ No cervical lacerations, uterine perforations or hospitalizations occurred } \\
\hline \multicolumn{3}{|l|}{ Risk of bias } \\
\hline Item & Authors' judgement & Description \\
\hline Allocation concealment? & Unclear & B- Unclear \\
\hline
\end{tabular}


Ho 1983

\begin{tabular}{|c|c|c|}
\hline Methods & \multicolumn{2}{|c|}{ Double blinded placebo-controlled trial by random number generation, blocks of 10} \\
\hline Participants & \multicolumn{2}{|c|}{$\begin{array}{l}120 \text { women randomised. } \\
\text { Included: women aged } 21-33 \text { with average gestational age of } 10 \text { weeks }(9.1-10.3) \text {. Excluded: women with } \\
\text { signs of threatened abortion, history of atopy or serious medical disease or pregnancy beyond first trimester } \\
\text { Hospital setting, Hong Kong. }\end{array}$} \\
\hline Interventions & \multicolumn{2}{|c|}{$\begin{array}{l}3 \mathrm{~h} \text { prior to procedure, women received 1) } 1 \mathrm{mg} \mathrm{16}, 16 \text {,-dimethyl-trans delta2-porostaglandin E1 methyl } \\
\text { ester or 2) placebo }\end{array}$} \\
\hline Outcomes & \multicolumn{2}{|c|}{ Side-effects, cervical dilation, blood loss, complications } \\
\hline Notes & \multicolumn{2}{|c|}{ One cervical laceration in the placebo group occurred. There were no uterine perforations } \\
\hline \multicolumn{3}{|l|}{ Risk of bias } \\
\hline Item & Authors' judgement & Description \\
\hline Allocation concealment? & Yes & A-Adequate \\
\hline
\end{tabular}

\section{Inal 2003}

\begin{tabular}{|c|c|c|}
\hline Methods & \multicolumn{2}{|c|}{ Double-blinded, randomised controlled trial (method not described) } \\
\hline Participants & \multicolumn{2}{|c|}{$\begin{array}{l}120 \text { women. Included: women with gestational age within the } 1 \text { st trimester. Gestational age was deter- } \\
\text { mined by ultrasonography } \\
\text { Hospital setting, Turkey. }\end{array}$} \\
\hline Interventions & \multicolumn{2}{|c|}{$\begin{array}{l}10 \mathrm{~h} \text { prior to procedure, received 1) } 200 \mu \mathrm{g} \text { misoprostol orally 2) } 200 \mu \mathrm{g} \text { misoprostol vaginally 3) oral } \\
\text { placebo or 4) vaginal placebo }\end{array}$} \\
\hline Outcomes & \multicolumn{2}{|c|}{ Cervical dilation, length of procedure, side-effects, expulsion } \\
\hline Notes & \multicolumn{2}{|c|}{ Attempted to clarify randomisation and allocation with author but received no response } \\
\hline \multicolumn{3}{|l|}{ Risk of bias } \\
\hline Item & Authors' judgement & Description \\
\hline Allocation concealment? & Unclear & B- unclear \\
\hline
\end{tabular}


Jurgenson 1989

\begin{tabular}{|c|c|c|}
\hline Methods & \multicolumn{2}{|c|}{ Randomised controlled study (method not described) } \\
\hline Participants & \multicolumn{2}{|c|}{$\begin{array}{l}40 \text { women randomised. } \\
\text { Included: healthy, nulliparous women in first trimester. Confirmed gestational age by US } \\
\text { Hospital setting, Sweden. }\end{array}$} \\
\hline Interventions & \multicolumn{2}{|c|}{$\begin{array}{l}4 \mathrm{~h} \text { prior to procedure, women received 1) 16,16 dimethyl-trans-delta-PGE1 (Cervagem } ®) \text { or 2) one } \\
\text { Dilapan }{ }^{\circledR}(4 \times 65 \mathrm{~mm})\end{array}$} \\
\hline Outcomes & \multicolumn{2}{|c|}{ Initial cervical dilation, need for additional dilation, blood loss } \\
\hline Notes & \multicolumn{2}{|c|}{$\begin{array}{l}\text { Attempted to clarify randomisation and allocation with author but received no response } \\
\text { No cervical lacerations, uterine perforations or hospitalizations occurred }\end{array}$} \\
\hline \multicolumn{3}{|l|}{ Risk of bias } \\
\hline Item & Authors' judgement & Description \\
\hline Allocation concealment? & Unclear & B- unclear \\
\hline
\end{tabular}

MacIsaac 1999

\begin{tabular}{|c|c|c|}
\hline Methods & \multicolumn{2}{|c|}{$\begin{array}{l}\text { Placebo-controlled double-blinded (or, at least provider-blinded) trial with randomisation performed by } \\
\text { using a computer-generated, random-number-producing algorithm with randomly permuted fixed blocks } \\
\text { of seven. Allocation by sequential, opaque, sealed envelopes }\end{array}$} \\
\hline Participants & \multicolumn{2}{|c|}{$\begin{array}{l}106 \text { women randomised. Included: women }>16 \text { years between } 7-14 \text { weeks gestation, willing to comply } \\
\text { with standard treatment and speaking either English or Spanish. Excluded women who were intolerant/ } \\
\text { allergic to misoprostol, who had severe asthma or hypertension requiring daily medication. Confirmed } \\
\text { gestational age by US } \\
\text { Hospital setting, USA. }\end{array}$} \\
\hline Interventions & \multicolumn{2}{|c|}{$\begin{array}{l}\text { Approximately } 4 \mathrm{~h} \text { prior to procedure: 1) one medium laminaria; 2) } 400 \mu \mathrm{g} \text { misoprostol vaginally; 3) } 400 \\
\mu \mathrm{g} \text { misoprostol orally }\end{array}$} \\
\hline Outcomes & \multicolumn{2}{|c|}{ Cervical dilation, need for additional dilation, blood loss, procedure duration, side-effects, acceptability } \\
\hline Notes & \multicolumn{2}{|c|}{$\begin{array}{l}\text { No cervical lacerations or uterine perforations occurred. Although unplanned expulsion not reported, } 5 \\
\text { women who received misoprostol had their procedures early due to vaginal bleeding }\end{array}$} \\
\hline \multicolumn{3}{|l|}{ Risk of bias } \\
\hline Item & Authors' judgement & Description \\
\hline Allocation concealment? & Yes & A-adequate \\
\hline
\end{tabular}


MacKenzie 1990

\begin{tabular}{|c|c|c|}
\hline Methods & \multicolumn{2}{|c|}{ Randomisation by random number table } \\
\hline Participants & \multicolumn{2}{|c|}{$\begin{array}{l}1030 \text { women randomised. } \\
\text { Included: women aged } 16-47 \text { who were not more than } 13 \text { weeks gestation. Exclusion criteria not stated } \\
\text { Hospital setting, UK. }\end{array}$} \\
\hline Interventions & \multicolumn{2}{|c|}{$\begin{array}{l}\text { Morning of procedure (1-4 h prior to procedure), women received 1) } 10 \mathrm{mg} \text { vaginal pessary of PGE2 or } \\
\text { 2) gemeprost } 1 \mathrm{mg}\end{array}$} \\
\hline Outcomes & \multicolumn{2}{|c|}{$\begin{array}{l}\text { Initial dilation, need for and ease of further dilation, surgical complications (uterine/ cervical injury) and } \\
\text { blood loss }\end{array}$} \\
\hline Notes & \multicolumn{2}{|c|}{$\begin{array}{l}\text { There were } 28 \text { (gemeprost) and } 33 \text { (PGE) cervical lacerations and } 7 \text { (gemeprost) and } 1 \text { (PGE) uterine } \\
\text { perforations during this study }\end{array}$} \\
\hline \multicolumn{3}{|l|}{ Risk of bias } \\
\hline Item & Authors' judgement & Description \\
\hline Allocation concealment? & Unclear & B- unclear \\
\hline
\end{tabular}

Morris 1986

\begin{tabular}{|c|c|c|}
\hline Methods & \multicolumn{2}{|c|}{ Randomised controlled trial } \\
\hline Participants & \multicolumn{2}{|c|}{$\begin{array}{l}60 \text { women. } \\
\text { Included: women who had not been pregnant before, were between } 6-13 \text { weeks, and had never undergone } \\
\text { any gynaecological surgery } \\
\text { Hospital setting, Australia. }\end{array}$} \\
\hline Interventions & \multicolumn{2}{|c|}{$12 \mathrm{~h}$ prior, women received 1) laminaria 2) PGF2a gel $(20 \mathrm{mg}) 3)$ no treatment } \\
\hline Outcomes & \multicolumn{2}{|c|}{ Cervial dilation, ease of further dilation, blood loss } \\
\hline Notes & \multicolumn{2}{|c|}{$\begin{array}{l}\text { Attempted to clarify randomisation and allocation with author but received no response. No hospitaliza- } \\
\text { tions as a result of abortion complications. Five unplanned expulsions in PGF group }\end{array}$} \\
\hline \multicolumn{3}{|l|}{ Risk of bias } \\
\hline Item & Authors' judgement & Description \\
\hline Allocation concealment? & Unclear & B- unclear \\
\hline
\end{tabular}


Ngai 1995

\begin{tabular}{|c|c|}
\hline Methods & $\begin{array}{l}\text { Double-blind randomised controlled trial, with randomisation and allocation performed as described in } \\
\text { Clinical trials: Design, conduct and analysis. }\end{array}$ \\
\hline Participants & $\begin{array}{l}75 \text { women randomised. } \\
\text { Included: women with gestations between } 42-84 \text { days } \\
\text { Average age } 20-21 \text { in misoprostol group and } 24-25 \text { in placebo group. Average gestational age of } 9 \text { weeks } \\
\text { (8.9-9.3) } \\
\text { Clinic setting, Hong Kong. }\end{array}$ \\
\hline Interventions & $12 \mathrm{~h}$ prior, women took 1) placebo (vitamin B) 2) misoprostol $400 \mu \mathrm{g}$ orally \\
\hline Outcomes & Cervical dilation, need for further dilation, ease of dilation, blood loss \\
\hline Notes & $\begin{array}{l}\text { One cervical laceration occurred in the placebo group. There were } 2 \text { repeat curretages for incomplete } \\
\text { procedure, one in each treatment group }\end{array}$ \\
\hline \multicolumn{2}{|l|}{ Risk of bias } \\
\hline Item & Authors' judgement \\
\hline Allocation concealment? & B- unclear \\
\hline
\end{tabular}

\section{Ngai 1999}

Methods $\quad$ Randomised controlled trial, with randomisation and allocation performed as described in Clinical trials: Design, conduct and analysis.

225 women randomised.
Participants
Included: nulliparous women between 56-84 days gestation with normal general and GYN history
Hospital setting, Hong Kong.

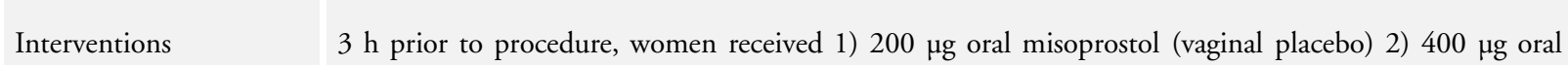
misoprostol (vaginal placebo) 3) oral placebo and $200 \mu \mathrm{g}$ vaginal misoprostol 4) oral placebo and $400 \mu \mathrm{g}$ vaginal misoprostol 5) oral and vaginal placebo

Outcomes Cervical dilation, further dilation and force needed, blood loss

Notes No cervical lacerations, uterine perforations or unplanned expulsions occurred

\section{Risk of bias}

\begin{tabular}{|c|c|c|}
\hline Item & Authors' judgement & Description \\
\hline Allocation concealment? & Unclear & B- unclear \\
\hline
\end{tabular}


Ngai, Yeung 1995

\begin{tabular}{|c|c|}
\hline Methods & $\begin{array}{l}\text { Randomised controlled trial, with randomisation and allocation performed as described in Clinical trials: } \\
\text { Design, conduct and analysis. }\end{array}$ \\
\hline Participants & $\begin{array}{l}64 \text { women randomised } \\
\text { Included: nulliparous women between } 42-84 \text { days gestation (confirmed by either physical examination } \\
\text { or ultrasound) } \\
\text { Clinic setting, Hong Kong. }\end{array}$ \\
\hline Interventions & $\begin{array}{l}12 \mathrm{~h} \text { prior, women took either 1) } 400 \mu \mathrm{g} \text { misoprostol or 2) placebo and then } 3 \mathrm{~h} \text { prior } 1 \mathrm{mg} \text { gemeprost } \\
\text { placed vaginally }\end{array}$ \\
\hline Outcomes & Cervical dilation, further dilation needed, blood loss \\
\hline Notes & No cervical lacerations, uterine perforations or hospitalizations occurred \\
\hline \multicolumn{2}{|l|}{ Risk of bias } \\
\hline Item & Authors' judgement \\
\hline Allocation concealment? & B- unclear \\
\hline
\end{tabular}

Okanlomo 1999

\begin{tabular}{|c|c|c|}
\hline Methods & \multicolumn{2}{|c|}{$\begin{array}{l}\text { Double-blinded randomised trial by computer generated numbers and allocation using sealed, opaque } \\
\text { sequential envelopes }\end{array}$} \\
\hline Participants & \multicolumn{2}{|c|}{$\begin{array}{l}136 \text { women randomised. } \\
\text { Included: healthy women between 6-12 weeks gestation, with no medical disorders. Excluded: women } \\
\text { with malodorous vaginal discharge or anxiety } \\
\text { Clinic setting, South Africa. }\end{array}$} \\
\hline Interventions & \multicolumn{2}{|c|}{$\begin{array}{l}12 \mathrm{~h} \text { and } 4 \mathrm{~h} \text { prior, women received 1) } 600 \mu \mathrm{g} \text { and } 400 \mu \mathrm{g} \text { misoprostol (vaginal 1st dose, oral 2nd dose) } \\
\text { 2) placebo }\end{array}$} \\
\hline Outcomes & \multicolumn{2}{|c|}{$\begin{array}{l}\text { Cervical dilation, procedure length, estimated gestational age from products of conception, and visual } \\
\text { analog score of pain experience }\end{array}$} \\
\hline Notes & \multicolumn{2}{|c|}{ No cervical lacerations or uterine perforations occurred. } \\
\hline \multicolumn{3}{|l|}{ Risk of bias } \\
\hline Item & Authors' judgement & Description \\
\hline Allocation concealment? & Yes & A-Adequate \\
\hline
\end{tabular}


Oppegaard 2004

\begin{tabular}{|c|c|}
\hline Methods & $\begin{array}{l}\text { Double-blinded randomised controlled trial, with randomisation performed with permuted blocks using } \\
\text { a randomisation plan generator. Allocation by sealed, opaque, sequentially numbered envelopes }\end{array}$ \\
\hline Participants & $\begin{array}{l}600 \text { women randomised. } \\
\text { Included: women with viable pregnancies between } 7-12 \text { weeks. Excluded: women who did not speak } \\
\text { Norwegean or English, with a known allergy to misoprostol or gestational age outside of the } 7-12 \text { weeks. } \\
\text { Confirmed gestational age by US } \\
\text { Clinic setting, Norway. }\end{array}$ \\
\hline Interventions & $\begin{array}{l}\text { The night before the procedure, women took either 1) oral misoprostol } 400 \mu \mathrm{g} \text { 2) oral misoprostol } 200 \\
\mu \mathrm{g}\end{array}$ \\
\hline Outcomes & Cervical dilation, blood loss \\
\hline Notes & No unplanned expulsions occurred. \\
\hline \multicolumn{2}{|l|}{ Risk of bias } \\
\hline Item & Authors' judgement \\
\hline Allocation concealment? & A-adequate \\
\hline
\end{tabular}

\section{Oppegaard 2006}

\begin{tabular}{|c|c|c|}
\hline Methods & \multicolumn{2}{|c|}{$\begin{array}{l}\text { Randomisation was performed with permuted blocks using a randomisation plan generator. Allocation } \\
\text { by sealed, opaque, sequential envelopes }\end{array}$} \\
\hline Participants & \multicolumn{2}{|c|}{$\begin{array}{l}338 \text { women randomised. } \\
\text { Included women with viable pregnancies between } 7-12 \text { weeks. Exclusion: speaking a language other than } \\
\text { Norwegean or English or known allergy to misoprostol. Confirmed gestational age by US } \\
\text { Clinic setting, Norway. }\end{array}$} \\
\hline Interventions & \multicolumn{2}{|c|}{ 1) $400 \mu \mathrm{g}$ vaginal misoprostol 2) $400 \mu \mathrm{g}$ oral misoprostol } \\
\hline Outcomes & \multicolumn{2}{|c|}{ Cervical dilation, pain, acceptability } \\
\hline Notes & \multicolumn{2}{|c|}{$\begin{array}{l}\text { One cervical laceration occurred in the oral misoprostol group; there were no uterine perforations or } \\
\text { hospitalizations }\end{array}$} \\
\hline \multicolumn{3}{|l|}{ Risk of bias } \\
\hline Item & Authors' judgement & Description \\
\hline Allocation concealment? & Yes & A-Adequate \\
\hline
\end{tabular}


Osmers 1990

\begin{tabular}{|c|c|}
\hline Methods & Placebo-controlled, double blinded randomised controlled trial (method of randomisation not described) \\
\hline Participants & $\begin{array}{l}50 \text { women randomised. } \\
\text { Included: nulliparous, healthy women between } 7-12 \text { weeks aged } 15-38 \text { years. Confirmed gestational age } \\
\text { by US } \\
\text { Hospital setting, Germany. }\end{array}$ \\
\hline Interventions & $6 \mathrm{~h}$ prior to procedure 1) placebo 2) intracervical gel of $500 \mu \mathrm{g}$ PGE2 \\
\hline Outcomes & Pain, cervical dilation, blood loss \\
\hline Notes & $\begin{array}{l}\text { Attempted to clarify randomisation and allocation with author but received no response. One cervical } \\
\text { laceration occurred in the placebo group; there were no uterine perforations. Two women in the placebo } \\
\text { group required re-evacuation }\end{array}$ \\
\hline \multicolumn{2}{|l|}{ Risk of bias } \\
\hline Item & Authors' judgement \\
\hline Allocation concealment? & B- unclear \\
\hline
\end{tabular}

Rabe 1985

\begin{tabular}{|c|c|c|}
\hline Methods & \multicolumn{2}{|c|}{ Placebo- controlled double-blinded randomised trial (randomisation method not further described) } \\
\hline Participants & \multicolumn{2}{|c|}{$\begin{array}{l}109 \text { women randomised. } \\
\text { Included: women between 9-12 weeks gestation, aged 18-42. Exclusions: threatened abortion, previous } \\
\text { gynaecological operation, prostaglandin allergy, cardiovascular disease, ulcerative colitis, diabetes, coagu- } \\
\text { lation problems, thalassaemia, renal insufficiency, glomerulonephritis, or epilepsy } \\
\text { Hospital setting, Germany. }\end{array}$} \\
\hline Interventions & \multicolumn{2}{|c|}{$\begin{array}{l}3 \text { hours before the intervention, the medication was placed into the posterior fornix followed by } 1 \text { hour } \\
\text { of bedrest, either 1) Gemeprost } 1 \mathrm{mg} / \mathrm{pv} \text {; }\end{array}$} \\
\hline Outcomes & \multicolumn{2}{|c|}{$\begin{array}{l}\text { Status of the cervix (firm/soft/open), difficulty of dilation (subjective measurement and size of hegar } \\
\text { dilator), side-effects }\end{array}$} \\
\hline \multicolumn{3}{|l|}{ Notes } \\
\hline \multicolumn{3}{|l|}{ Risk of bias } \\
\hline Item & Authors' judgement & Description \\
\hline Allocation concealment? & Unclear & B-unclear \\
\hline
\end{tabular}


Radestad 1988

\begin{tabular}{|c|c|}
\hline Methods & Randomised clinical trial (method of randomisation and allocation concealment not described) \\
\hline Participants & $\begin{array}{l}42 \text { women randomised. } \\
\text { Included: women with gestational ages between } 7-11 \text { weeks. Ultrasound used to confirm gestational age } \\
\text { Sweden, unclear setting. }\end{array}$ \\
\hline Interventions & 12 and $24 \mathrm{~h}$ prior, women received 1) mifepristone $100 \mathrm{mg}$ or 2) placebo \\
\hline Outcomes & Force of dilation, cervical dilation, side-effects \\
\hline Notes & $\begin{array}{l}\text { Attempted to clarify randomisation and allocation with author but received no response. No cervical } \\
\text { lacerations or uterine perforations occurred }\end{array}$ \\
\hline \multicolumn{2}{|l|}{ Risk of bias } \\
\hline Item & Authors' judgement \\
\hline Allocation concealment? & B-unclear \\
\hline
\end{tabular}

Radestad 1989

\begin{tabular}{|c|c|c|}
\hline Methods & \multicolumn{2}{|c|}{ Randomised controlled trial (methods of randomisation and allocation concealment not described) } \\
\hline Participants & \multicolumn{2}{|c|}{$\begin{array}{l}45 \text { women randomised. } \\
\text { Included: women with gestational age between } 6-11 \text { weeks, with no history of spontaneous abortion, } \\
\text { cesarean section or cervical procedures. Ultrasound used for gestational age dating } \\
\text { Hospital setting, Sweden. }\end{array}$} \\
\hline Interventions & \multicolumn{2}{|c|}{ 3-4 h prior to procedure, women received 1) Lamicel, $3 \mathrm{~mm}$ or 2) synthetic sponge without MgSO4 } \\
\hline Outcomes & \multicolumn{2}{|c|}{ Cervical dilation, force needed for further dilation, blood loss } \\
\hline Notes & \multicolumn{2}{|c|}{ Attempted to clarify randomisation and allocation with author but received no response } \\
\hline \multicolumn{3}{|l|}{ Risk of bias } \\
\hline Item & Authors' judgement & Description \\
\hline Allocation concealment? & Unclear & B- unclear \\
\hline
\end{tabular}

Rath 1983

\begin{tabular}{l|l}
\hline Methods & Double-blinded randomised trial \\
\hline Participants & $\begin{array}{l}30 \text { women randomised. } \\
\text { Included: nulliparous women in the first trimester who were healthy, without gynaecologic or internal } \\
\text { disorders } \\
\text { Hospital setting, Germany }\end{array}$ \\
\hline $\begin{array}{l}\text { Cervical preparation for first trimester surgical abortion (Review) } \\
\text { Copyright @ 2010 The Cochrane Collaboration. Published by John Wiley \& Sons, Ltd. }\end{array}$
\end{tabular}


Rath 1983 (Continued)

\begin{tabular}{|c|c|c|}
\hline Interventions & \multicolumn{2}{|c|}{$\begin{array}{l}\text { Intracervical placement } 8 \mathrm{~h} \text { prior to procedure of 1) } 0.5 \mathrm{mg} \text { PGE2 gel 2) } 0.05 \mathrm{mg} \text { sulprostone gel or } 3 \text { ) } \\
0.1 \mathrm{mg} \text { sulprostone gel }\end{array}$} \\
\hline Outcomes & \multicolumn{2}{|c|}{ Cervical dilation, ease of passage through canal measured by tonometry, bleeding, pain, abortion } \\
\hline Notes & \multicolumn{2}{|c|}{$\begin{array}{l}\text { Attempted to clarify randomisation and allocation with author but received no response. There were } 2 \\
\text { cervical lacerations in the PGE2 group; no uterine perforations occurred }\end{array}$} \\
\hline \multicolumn{3}{|l|}{ Risk of bias } \\
\hline Item & Authors' judgement & Description \\
\hline Allocation concealment? & Unclear & B- unclear \\
\hline
\end{tabular}

Rath 1985

\begin{tabular}{|c|c|c|}
\hline Methods & \multicolumn{2}{|c|}{ Randomised controlled trial } \\
\hline Participants & \multicolumn{2}{|c|}{$\begin{array}{l}60 \text { women randomised. } \\
\text { Included women in the first trimester with an average gestational age of } 10 \text { weeks } \\
\text { Hospital setting, Germany }\end{array}$} \\
\hline Interventions & \multicolumn{2}{|c|}{ 6-8 h prior to procedure, women received intracervical sulprostone 1) $25 \mu \mathrm{g}$ 2) $50 \mu \mathrm{g}$ or 3) $100 \mu \mathrm{g}$} \\
\hline Outcomes & \multicolumn{2}{|c|}{ Cervical dilation, force needed to dilate, success of dilation, pain and side-effects } \\
\hline Notes & \multicolumn{2}{|c|}{$\begin{array}{l}\text { Attempted to clarify randomisation and allocation with author but received no response. No uterine } \\
\text { perforations or hospitalizations occurred }\end{array}$} \\
\hline \multicolumn{3}{|l|}{ Risk of bias } \\
\hline Item & Authors' judgement & Description \\
\hline Allocation concealment? & Unclear & B-unclear \\
\hline
\end{tabular}

\section{Shalev 1988}

\begin{tabular}{l|l}
\hline Methods & Double-blinded, randomised controlled trial (method not described) \\
\hline Participants & $\begin{array}{l}40 \text { women randomised. Included nulliparous women between 16-25 years with gestational age between } \\
7-12 \text { weeks } \\
\text { Hospital setting, Israel }\end{array}$ \\
\hline Interventions & Intracervical placement the night before procedure of: 1) PGE2 gel 1 mg or 2) placebo \\
\hline Outcomes & Cervical dilation, difficulty of procedure, side-effects \\
\hline $\begin{array}{l}\text { Cervical preparation for first trimester surgical abortion (Review) } \\
\text { Copyright } \odot 2010 \text { The Cochrane Collaboration. Published by John Wiley \& Sons, Ltd. }\end{array}$
\end{tabular}




\section{Shalev 1988 (Continued)}

\begin{tabular}{|c|c|c|}
\hline Notes & \multicolumn{2}{|c|}{$\begin{array}{l}\text { Attempted to clarify randomisation and allocation with author but received no response. No cervical } \\
\text { lacerations or uterine perforations occurred. There was one reaspiration in the placebo group }\end{array}$} \\
\hline \multicolumn{3}{|l|}{ Risk of bias } \\
\hline Item & Authors' judgement & Description \\
\hline Allocation concealment? & Unclear & B-unclear \\
\hline
\end{tabular}

Sharma 2005

\begin{tabular}{|c|c|c|}
\hline Methods & \multicolumn{2}{|c|}{ Randomised controlled trial using computer-generated random number generation } \\
\hline Participants & \multicolumn{2}{|c|}{$\begin{array}{l}90 \text { women randomised. } \\
\text { Included healthy women }>18 \text { years old, between } 7-10 \text { weeks gestation who had no contraindication to } \\
\text { misoprostol use. Excluded women with possible threatened abortion. Confirmed gestational age dating } \\
\text { by ultrasound } \\
\text { Hospital setting, UK. }\end{array}$} \\
\hline Interventions & \multicolumn{2}{|c|}{60 minutes prior to procedure: 1) oral miso $400 \mu \mathrm{g}$ 2) vaginal miso $800 \mu \mathrm{g} 3$ ) no treatment } \\
\hline Outcomes & \multicolumn{2}{|c|}{ Force required to dilate cervix, initial dilation } \\
\hline Notes & \multicolumn{2}{|c|}{ Allocation method not described. No cervical lacerations or uterine perforations occurred } \\
\hline \multicolumn{3}{|l|}{ Risk of bias } \\
\hline Item & Authors' judgement & Description \\
\hline Allocation concealment? & Unclear & B- unclear \\
\hline
\end{tabular}

\section{Singh 1998}

\begin{tabular}{|c|c|}
\hline Methods & $\begin{array}{l}\text { Double-blinded randomised controlled trial; randomisation as described in Clinical trials: Design, conduct } \\
\text { and analysis, and allocation by sealed, opaque, sequential envelopes }\end{array}$ \\
\hline Participants & $\begin{array}{l}\text { Randomised } 120 \text { women. } \\
\text { Included: nulliparous women in the first trimester. Ultrasound was used to confirm gestational age } \\
\text { Hospital setting, Singapore }\end{array}$ \\
\hline Interventions & $\begin{array}{l}3-4 \mathrm{~h} \text { prior to procedure, vaginal administration of misoprostol at doses of 1) } 200 \mu \mathrm{g} \text { 2) } 400 \mu \mathrm{g} \text { 3) } 600 \\
\mu \mathrm{g} \text {, or 4) } 800 \mu \mathrm{g}\end{array}$ \\
\hline Outcomes & Cervical dilation, side-effects, need for further dilation, blood loss \\
\hline Notes & \\
\hline
\end{tabular}


Singh 1998 (Continued)

\section{Risk of bias}

\begin{tabular}{lll}
\hline Item & Authors' judgement & Description \\
\hline Allocation concealment? & Yes & A- adequate \\
\hline
\end{tabular}

\section{Singh 1999}

\begin{tabular}{|c|c|c|}
\hline Methods & \multicolumn{2}{|c|}{$\begin{array}{l}\text { Double blinded, randomised controlled trial. Randomisation by random number tables and allocation by } \\
\text { sequential, sealed, opaque envelopes }\end{array}$} \\
\hline Participants & \multicolumn{2}{|c|}{$\begin{array}{l}60 \text { women randomised. } \\
\text { Included: nulliparae between } 6-11 \text { weeks with } \mathrm{Hgb}>10 \text {. Gestational age confirmed by US or pelvic exam } \\
\text { Hospital setting, Singapore }\end{array}$} \\
\hline Interventions & \multicolumn{2}{|c|}{ Misoprostol administered either 1) $600 \mu \mathrm{g}$ vaginally $2 \mathrm{~h}$ prior 3) $400 \mu \mathrm{g} 3 \mathrm{~h}$ prior } \\
\hline Outcomes & \multicolumn{2}{|c|}{ Cervical dilation, need for further dilation, blood loss } \\
\hline Notes & \multicolumn{2}{|c|}{ There were no hospitalizations or unplanned expulsions. } \\
\hline \multicolumn{3}{|l|}{ Risk of bias } \\
\hline Item & Authors' judgement & Description \\
\hline Allocation concealment? & Yes & A- adequate \\
\hline
\end{tabular}

\section{Singh, Fong 1999}

\begin{tabular}{ll}
\hline Methods & $\begin{array}{l}\text { Randomised controlled trial. Randomisation by random number tables and allocation by sequential, } \\
\text { opaque envelopes }\end{array}$ \\
\hline Participants & $\begin{array}{l}180 \text { women randomised. } \\
\text { Included nulliparae between } 6-11 \text { weeks gestation with Hgb }>10 \\
\text { Hospital setting, Singapore. }\end{array}$ \\
\hline Interventions & $\begin{array}{l}\text { Prior to procedure, women received misoprostol vaginally 1) } 400 \mu \mathrm{g} 3 \text { h prior 2) } 600 \mu \mathrm{g} 2 \mathrm{~h} \text { prior 3) } 800 \\
\mu \mathrm{g} 2 \mathrm{~h} \text { prior }\end{array}$ \\
\hline Outcomes & Cervical dilation, blood loss, successful dilation \\
\hline Notes & There were no unplanned expulsions. \\
\hline
\end{tabular}

\section{Risk of bias}

Item Authors' judgement $\quad$ Description


Singh, Fong 1999 (Continued)

\begin{tabular}{|c|c|c|}
\hline Allocation concealment? & Yes & A-adequate \\
\hline \multicolumn{3}{|l|}{ Stornes 1991} \\
\hline Methods & \multicolumn{2}{|c|}{ Randomised clinical trial. } \\
\hline Participants & \multicolumn{2}{|c|}{$\begin{array}{l}108 \text { women randomised. } \\
\text { Included: nulliparae between 7-12 weeks who were 19-24 years old. Excluded: women with asthma, } \\
\text { cardiovascular insufficiency, elevated ocular pressure, or allergies to prostaglandins } \\
\text { Hospital setting, Denmark }\end{array}$} \\
\hline Interventions & \multicolumn{2}{|c|}{$\begin{array}{l}4 \mathrm{~h} \text { prior to procedure, women received 1) gemprost vaginal pessary or 2) Lamicel tent ( } 3 \mathrm{~mm} \text { except for } \\
\text { last } 3 \text { patients who received } 5 \mathrm{~mm} \text { ) }\end{array}$} \\
\hline Outcomes & \multicolumn{2}{|c|}{ Cervical dilation, whether further dilation needed, blood loss, complications } \\
\hline Notes & \multicolumn{2}{|c|}{$\begin{array}{l}\text { Allocation per sealed, opaque, sequential envelopes, per author. Randomisation method unclear. There } \\
\text { was one hospitalization in the Lamicel group }\end{array}$} \\
\hline \multicolumn{3}{|l|}{ Risk of bias } \\
\hline Item & Authors' judgement & Description \\
\hline Allocation concealment? & Yes & A- adequate \\
\hline
\end{tabular}

Tang 2004

\begin{tabular}{|c|c|c|}
\hline Methods & \multicolumn{2}{|c|}{ Single-blinded trial with randomisation by computer-generated random numbers } \\
\hline Participants & \multicolumn{2}{|c|}{$\begin{array}{l}80 \text { women randomised. } \\
\text { Included nulliparae }<12 \text { weeks gestation with a normal general and gynaecologic history and with a normal } \\
\text { physical exam. Excluded women taking long-term medication, who had an IUD in situ, who were heavy } \\
\text { smokers, or had an allergy to misoprostol. Ultrasound was used to confirm gestational ages in some cases } \\
\text { Hospital setting, Hong Kong }\end{array}$} \\
\hline Interventions & \multicolumn{2}{|c|}{$3 \mathrm{~h}$ prior to procedure, women received $400 \mu \mathrm{g}$ misoprostol either 1) sublingually or 2) vaginally } \\
\hline Outcomes & \multicolumn{2}{|c|}{ Cervical dilation, force needed to further dilate, blood loss } \\
\hline Notes & \multicolumn{2}{|c|}{ There were no cervical lacerations or uterine perforations. } \\
\hline \multicolumn{3}{|l|}{ Risk of bias } \\
\hline Item & Authors' judgement & Description \\
\hline Allocation concealment? & Unclear & B- unclear \\
\hline
\end{tabular}

Cervical preparation for first trimester surgical abortion (Review)

Copyright (๑) 2010 The Cochrane Collaboration. Published by John Wiley \& Sons, Ltd. 
Vimala 2003

\begin{tabular}{|c|c|c|}
\hline Methods & \multicolumn{2}{|c|}{ Randomised controlled trial with allocation by sequential, opaque, sealed envelopes } \\
\hline Participants & \multicolumn{2}{|c|}{$\begin{array}{l}60 \text { women randomised. } \\
\text { Included women between 6-11 weeks gestation and excluded those with obstetric or gynaecologic com- } \\
\text { plications or an allergy to misoprostol. Ultrasound used to confirm dating in some cases } \\
\text { Hospital setting, India. }\end{array}$} \\
\hline Interventions & \multicolumn{2}{|c|}{$2 \mathrm{~h}$ prior to procedure, women received either 1) $400 \mu \mathrm{g}$ sublingual misoprostol or 2) pyridoxine (placebo) } \\
\hline Outcomes & \multicolumn{2}{|c|}{ Side-effects, cervical dilation, need for further dilation, blood loss } \\
\hline Notes & \multicolumn{2}{|c|}{ No uterine perforations occurred. } \\
\hline \multicolumn{3}{|l|}{ Risk of bias } \\
\hline Item & Authors' judgement & Description \\
\hline Allocation concealment? & Yes & A- adequate \\
\hline
\end{tabular}

Vimala 2004

\begin{tabular}{|c|c|c|}
\hline Methods & \multicolumn{2}{|c|}{$\begin{array}{l}\text { Randomised controlled trial using random number table and allocation by sequential, opaque, sealed } \\
\text { envelopes }\end{array}$} \\
\hline Participants & \multicolumn{2}{|c|}{$\begin{array}{l}100 \text { women randomised. } \\
\text { Included women between } 6-12 \text { weeks gestation. Excluded those with medical problems, history of cervical } \\
\text { surgery or cesarean or an allergy to misoprostol. Gestational age confirmed by ultrasound } \\
\text { Hospital setting, India. }\end{array}$} \\
\hline Interventions & \multicolumn{2}{|c|}{$2 \mathrm{~h}$ prior to procedure, women received $400 \mu \mathrm{g}$ misoprostol 1) sublingually or 2) vaginally } \\
\hline Outcomes & \multicolumn{2}{|c|}{ Side- effects, cervical dilation, need for further dilation, duration of procedure, blood loss } \\
\hline Notes & \multicolumn{2}{|c|}{ No uterine perforations occurred. } \\
\hline \multicolumn{3}{|l|}{ Risk of bias } \\
\hline Item & Authors' judgement & Description \\
\hline Allocation concealment? & Yes & A- adequate \\
\hline
\end{tabular}




\begin{tabular}{|c|c|}
\hline Methods & $\begin{array}{l}\text { Randomised controlled trial using random number tables and allocated by sequential, opaque, sealed } \\
\text { envelopes }\end{array}$ \\
\hline Participants & $\begin{array}{l}60 \text { women randomised. } \\
\text { Included women with gestational age between } 9-12 \text { weeks. Excluded those with known heart disease, } \\
\text { asthma, a scarred uterus, or allergy or contraindications to prostglandins. Dating confirmed by ultrasound } \\
\text { Hospital setting, India }\end{array}$ \\
\hline Interventions & $\begin{array}{l}2 \mathrm{~h} \text { prior to procedure, women received either 1) } 400 \mu \mathrm{g} \text { sublingual misoprostol or 2) } 125 \mu \mathrm{g} \text { IM of } 15 \text { - } \\
\mathrm{m}-\mathrm{PG} \mathrm{F} \mathrm{F}_{2 a}\end{array}$ \\
\hline Outcomes & Side-effects, cervical dilation, need for further dilation, blood loss, satsifaction \\
\hline Notes & No uterine perforations occurred. \\
\hline \multicolumn{2}{|l|}{ Risk of bias } \\
\hline Item & Authors' judgement \\
\hline Allocation concealment? & A- adequate \\
\hline
\end{tabular}

Vimala, Mittal 2004

\begin{tabular}{|c|c|c|}
\hline Methods & \multicolumn{2}{|c|}{$\begin{array}{l}\text { Randomised controlled trial using random unumber tables and allocated by sequential, opaque, sealed } \\
\text { envelopes }\end{array}$} \\
\hline Participants & \multicolumn{2}{|c|}{$\begin{array}{l}120 \text { women randomised. } \\
\text { Included women between } 6-11 \text { weeks gestation. Excluded women with heart disease, asthma, known } \\
\text { allergy to prostaglandins, multiple pregnancies, or scarred uterus. Ultrasound used to confirm dating } \\
\text { Hospital setting, India }\end{array}$} \\
\hline Interventions & \multicolumn{2}{|c|}{$\begin{array}{l}2 \text { or } 3 \mathrm{~h} \text { prior to procedure, women received 1) } 400 \mu \mathrm{g} \text { sublingual misoprostol or 2) } 200 \mu \mathrm{g} \text { sublingual } \\
\text { misoprostol }\end{array}$} \\
\hline Outcomes & \multicolumn{2}{|c|}{ Side- effects, cervical dilation, need for further dilation, blood loss } \\
\hline Notes & \multicolumn{2}{|c|}{ No uterine perforations or hospitalizations occurred. } \\
\hline \multicolumn{3}{|l|}{ Risk of bias } \\
\hline Item & Authors' judgement & Description \\
\hline Allocation concealment? & Yes & A- adequate \\
\hline
\end{tabular}


Wang 1989

\begin{tabular}{l|l}
\hline Methods & Randomised controlled trial \\
\hline Participants & $\begin{array}{l}\text { 60 women randomised. } \\
\text { Included nulliparae between 6-11 weeks gestation. } \\
\text { China, unclear setting. }\end{array}$ \\
\hline Interventions & 12 h prior to procedure, women received: 1) PGF2a 1 mg suppository 2) placebo \\
\hline Outcomes & Cervical dilation, blood loss \\
\hline Notes & $\begin{array}{l}\text { Attempted to clarify randomisation and allocation with author but received no response. No cervical } \\
\text { lacerations or uterine perforations occurred }\end{array}$ \\
\hline Risk of bias & \begin{tabular}{l} 
Authors' judgement \\
\hline Item
\end{tabular} \\
\hline Allocation concealment? & Unclear \\
\hline
\end{tabular}

\section{WHO 1986}

\begin{tabular}{ll} 
Methods & $\begin{array}{l}\text { Randomised controlled trial by computer-generated random number table and allocation by sealed en- } \\
\text { velopes }\end{array}$ \\
\hline Participants & $\begin{array}{l}627 \text { randomised. Included nulliparae between } 8-12 \text { weeks gestation, over the legal age of consent. Excluded } \\
\text { women with cardiac disease (past or current), hypertension, respiratory disease, ulcerative colitis, diabetes, } \\
\text { disorders of blood coagulation, kidney disease, liver disease, sickle-cell, history of allergic reactions or any } \\
\text { other serious systemic disease } \\
11 \text { centers in } 9 \text { countries (Moscow, Stockholm, New Delhi, Szeged, Ljubljana, Chandigarh, Bombay, } \\
\text { Singapore, Hong Kong, Lusaka, Havana) }\end{array}$ \\
\hline Interventions & $\begin{array}{l}\text { 3-4 hours prior to procedure: 1) 0.5mg IM of 16-phenoxy-tetranor PGE2 methyl sulfonylamide 2) 1 mg } \\
\text { of vaginal 16, 16, dimethyl trans delta2 PGE1 methyl ester 3) 30 mg of vaginal 9 deoxo-16, 16-dimethyl- } \\
\text { 9-methylene PGE2 4) } 0.5 \text { mg of vaginal 15 methyl-PGF2a methyl ester, or 5) one medium-size laminaria } \\
\text { tent }\end{array}$ \\
\hline Cutcomes & \begin{tabular}{l} 
Cervical dilation, need for and ease of further dilation \\
\hline Notes
\end{tabular} \\
\hline
\end{tabular}

Risk of bias

\begin{tabular}{|c|c|c|}
\hline Item & Authors' judgement & Description \\
\hline Allocation concealment? & Unclear & B- unclear \\
\hline
\end{tabular}


WHO 1990

Methods

Double-blinded randomised controlled trial by computer-generated random number tables. Allocation method not described

Participants 230 randomised.

Included nulliparae between 18-35 years with normal general and gynaecologic history and exam and a living, intrauterine pregnancy between 70-84 days. Excluded women with past cervical surgery or dilation, or with current signs of threatened abortion and those who wished to start hormonal or intrauterine contraception within 1 month of abortion. Confirmed dating by ultrasound

6 centers (Aberdeen, Greifswald, Hong Kong, Singapore, Stockholm, Szeged)

Interventions

Women received 24 hours and 12 hours prior to procedure one of the following: 1) placebo 2) $25 \mathrm{mg}$ mifepristone 3) $50 \mathrm{mg}$ mifepristone or 4) $100 \mathrm{mg}$ mifepristone

Outcomes Cervical dilation, ease of dilation, blood loss, side-effects and complications

Notes $\quad$ Four cervical lacerations (randomisation groups not stated) and no uterine perforations occurred. Four women required reaspiration in the placebo group, as did 1 in the $25 \mathrm{mg}$ mifepristone group

Risk of bias

\begin{tabular}{l|ll}
\hline Item & Authors' judgement & Description \\
\hline Allocation concealment? & Unclear & B- unclear \\
\hline
\end{tabular}

Wiebe 1998

\begin{tabular}{|c|c|c|}
\hline Methods & \multicolumn{2}{|c|}{ Randomised controlled trial using a random number table. Allocation method by sealed envelopes } \\
\hline Participants & \multicolumn{2}{|l|}{$\begin{array}{l}93 \text { women randomised. } \\
\text { Included women with first trimester pregnancies } \\
\text { Canada, unclear setting }\end{array}$} \\
\hline Interventions & \multicolumn{2}{|c|}{$2 \mathrm{~h}$ prior to procedure, women received 1) placebo or 2) $750 \mu \mathrm{g}$ misoprostol vaginally } \\
\hline Outcomes & \multicolumn{2}{|l|}{ Cervical dilation, pain, side-effects } \\
\hline Notes & & \\
\hline \multicolumn{3}{|l|}{ Risk of bias } \\
\hline Item & Authors' judgement & Description \\
\hline Allocation concealment? & Unclear & B- unclear \\
\hline
\end{tabular}


Characteristics of excluded studies [ordered by study ID]

\begin{tabular}{|c|c|}
\hline Study & Reason for exclusion \\
\hline Bryman 1988 & Method of randomisation inadequate \\
\hline Frankman 1980 & Not randomised \\
\hline Heinzl 1987 & Method of randomisation inadequate \\
\hline Hulka 1987 & Did not report on any of our outcomes of interest \\
\hline Ivy Li 2003 & Studied nitric oxide donors, which are excluded from this review (subject of another review) \\
\hline Khanna 1980 & Included women with gestational ages in the second trimester \\
\hline Platz-Christensen & Comparisons were carried out consecutively over time \\
\hline Saxena 2004 & No allocation concealment \\
\hline Saxena 2006 & Method of randomisation inadequate \\
\hline Skjeldestad 1990 & Method of randomisation inadequate \\
\hline Vengadasalam 1981 & Not randomised \\
\hline
\end{tabular}

\section{Characteristics of ongoing studies [ordered by study ID]}

\section{von Hertzen}

\begin{tabular}{l|l}
\hline Trial name or title & Pretreatment with misoprostol before vacuum aspiration for first trimester induced abortion \\
\hline Methods & Randomised controlled trial \\
\hline Participants & 4972 women prior to surgical abortion $<12$ weeks gestation \\
\hline Interventions & Misoprostol $400 \mu$ versus placebo \\
\hline Outcomes & Need for further dilation and adverse events (uterine perforation, cervical laceration) \\
\hline Starting date & 2002 \\
\hline Contact information & Helena von Hertzen \\
\hline Notes & $\begin{array}{l}\text { completed enrolment in September 2005. Preparation is ongoing and should be forthcoming in the next year, } \\
\text { as per personal communication with Helena von Hertzen }\end{array}$ \\
\hline
\end{tabular}


DATA AND ANALYSES

Comparison 1. Misoprostol versus placebo

\begin{tabular}{|c|c|c|c|c|}
\hline Outcome or subgroup title & $\begin{array}{l}\text { No. of } \\
\text { studies }\end{array}$ & $\begin{array}{c}\text { No. of } \\
\text { participants }\end{array}$ & Statistical method & Effect size \\
\hline $\begin{array}{l}1 \text { Cervical dilation at procedure } \\
\text { start }\end{array}$ & 5 & & Mean Difference (IV, Fixed, 95\% CI) & Subtotals only \\
\hline $\begin{array}{l}\text { 1.1 Misoprostol } 400 \mu \mathrm{g} \text {, } \\
\text { vaginal }\end{array}$ & 2 & 161 & Mean Difference (IV, Fixed, 95\% CI) & $2.36[1.92,2.79]$ \\
\hline $\begin{array}{l}\text { 1.2 Misoprostol } 400 \mu \mathrm{g} \text {, } \\
\text { sublingual }\end{array}$ & 1 & 60 & Mean Difference (IV, Fixed, 95\% CI) & $4.30[3.53,5.07]$ \\
\hline 1.3 Misoprostol $600 \mu \mathrm{g}$, oral & 1 & 30 & Mean Difference (IV, Fixed, 95\% CI) & $1.40[0.51,2.29]$ \\
\hline $\begin{array}{l}\text { 1.4 Misoprostol } 600 \mu \mathrm{g} \text {, } \\
\text { vaginal }\end{array}$ & 1 & 278 & Mean Difference (IV, Fixed, 95\% CI) & $1.60[1.14,2.06]$ \\
\hline $\begin{array}{l}2 \text { Side-effects: occurrence of } \\
\text { nausea }\end{array}$ & 4 & 539 & Odds Ratio (M-H, Fixed, 95\% CI) & $1.71[1.10,2.66]$ \\
\hline $\begin{array}{l}2.1 \text { Misoprostol } 400 \mu \mathrm{g} \text {, } \\
\text { vaginal }\end{array}$ & 2 & 201 & Odds Ratio (M-H, Fixed, 95\% CI) & $2.35[1.11,4.98]$ \\
\hline $\begin{array}{l}\text { 2.2 Misoprostol } 400 \mu \mathrm{g} \text {, } \\
\text { sublingual }\end{array}$ & 1 & 60 & Odds Ratio (M-H, Fixed, 95\% CI) & $31.24[1.73,563.16]$ \\
\hline $\begin{array}{l}\text { 2.3 Misoprostol } 600 \mu \mathrm{g} \text {, } \\
\text { vaginal }\end{array}$ & 1 & 278 & Odds Ratio (M-H, Fixed, 95\% CI) & $0.97[0.53,1.80]$ \\
\hline 3 Procedure length (minutes) & 3 & & Mean Difference (IV, Fixed, 95\% CI) & Subtotals only \\
\hline $\begin{array}{l}3.1 \text { Misoprostol } 400 \mu \mathrm{g} \text {, } \\
\text { vaginal }\end{array}$ & 2 & 161 & Mean Difference (IV, Fixed, 95\% CI) & $-0.68[-1.17,-0.19]$ \\
\hline $\begin{array}{l}\text { 3.2 Misoprostol, } 400 \mu \mathrm{g} \text {, } \\
\text { sublingual }\end{array}$ & 1 & 60 & Mean Difference (IV, Fixed, 95\% CI) & $-3.5[-4.69,-2.31]$ \\
\hline
\end{tabular}

Comparison 2. Gemeprost $1 \mathrm{mg}$ versus placebo

\begin{tabular}{lcccc} 
Outcome or subgroup title & $\begin{array}{c}\text { No. of } \\
\text { studies }\end{array}$ & $\begin{array}{c}\text { No. of } \\
\text { participants }\end{array}$ & Statistical method & Effect size \\
\hline $\begin{array}{l}1 \text { Need for additional mechanical } \\
\text { dilation }\end{array}$ & 3 & 349 & Odds Ratio (M-H, Random, 95\% CI) & $0.04[0.00,0.51]$ \\
\hline
\end{tabular}




\begin{tabular}{lcclc} 
Outcome or subgroup title & $\begin{array}{c}\text { No. of } \\
\text { studies }\end{array}$ & $\begin{array}{c}\text { No. of } \\
\text { participants }\end{array}$ & \multicolumn{1}{c}{ Statistical method } & Effect size \\
\hline $\begin{array}{l}\text { 1 Need for additional mechanical } \\
\text { dilation }\end{array}$ & 3 & 168 & Odds Ratio (M-H, Fixed, 95\% CI) & $0.33[0.13,0.82]$ \\
$1.1100 \mathrm{mg}$ mifepristone & 1 & 108 & Odds Ratio (M-H, Fixed, 95\% CI) & $0.65[0.10,4.08]$ \\
$1.2200 \mathrm{mg}$ mifepristone & 1 & 30 & Odds Ratio (M-H, Fixed, 95\% CI) & $0.58[0.14,2.48]$ \\
1.3600 mg mifepristone & 1 & 30 & Odds Ratio (M-H, Fixed, 95\% CI) & $0.09[0.02,0.50]$ \\
$\begin{array}{l}\text { Cervical dilation at procedure } \\
\text { start }\end{array}$ & 4 & 232 & Mean Difference (IV, Fixed, 95\% CI) & $1.82[1.40,2.24]$ \\
2.1100 mg mifepristone & 1 & 108 & Mean Difference (IV, Fixed, 95\% CI) & $1.40[0.66,2.14]$ \\
$2.2200 \mathrm{mg}$ mifepristone & 2 & 94 & Mean Difference (IV, Fixed, 95\% CI) & $2.02[1.51,2.52]$ \\
$2.3600 \mathrm{mg}$ mifepristone & 1 & 30 & Mean Difference (IV, Fixed, 95\% CI) & Not estimable \\
\hline
\end{tabular}

\section{Comparison 4. Prostaglandin $\mathrm{F}_{2} \alpha$ versus placebo}

\begin{tabular}{lcccc} 
Outcome or subgroup title & $\begin{array}{c}\text { No. of } \\
\text { studies }\end{array}$ & $\begin{array}{c}\text { No. of } \\
\text { participants }\end{array}$ & Statistical method & Effect size \\
\hline $\begin{array}{l}1 \text { Need for additional mechanical } \\
\text { dilation }\end{array}$ & 1 & 287 & Odds Ratio (M-H, Fixed, 95\% CI) & $0.02[0.01,0.04]$ \\
\hline
\end{tabular}

Comparison 5. Prostaglandin $\mathrm{E}_{2}$ versus placebo

\begin{tabular}{|c|c|c|c|c|}
\hline Outcome or subgroup title & $\begin{array}{l}\text { No. of } \\
\text { studies }\end{array}$ & $\begin{array}{c}\text { No. of } \\
\text { participants }\end{array}$ & Statistical method & Effect size \\
\hline $\begin{array}{l}1 \text { Need for additional mechanical } \\
\text { dilation }\end{array}$ & 4 & & Odds Ratio (M-H, Fixed, 95\% CI) & Subtotals only \\
\hline $\begin{array}{l}1.11 \mathrm{mg} \text { prostaglandin } \mathrm{E}_{2} \text {, } \\
\text { intracervical }\end{array}$ & 1 & 40 & Odds Ratio (M-H, Fixed, 95\% CI) & Not estimable \\
\hline $\begin{array}{l}1.225 \mu \mathrm{g} 15 \text { methyl PGE2 } \\
\text { methyl ester, extra-amniotic }\end{array}$ & 1 & 50 & Odds Ratio (M-H, Fixed, 95\% CI) & Not estimable \\
\hline $1.31 \mathrm{mg} \mathrm{PGE} 2$, oral & 1 & 288 & Odds Ratio (M-H, Fixed, 95\% CI) & $0.23[0.12,0.43]$ \\
\hline $1.40 .5 \mathrm{mg}$ prostaglandin $\mathrm{E}_{2}$ & 1 & 50 & Odds Ratio (M-H, Fixed, 95\% CI) & $0.09[0.02,0.35]$ \\
\hline $\begin{array}{l}2 \text { Cervical dilation at procedure } \\
\text { start }\end{array}$ & 2 & 328 & Mean Difference (IV, Fixed, 95\% CI) & $6.8[5.99,7.61]$ \\
\hline $\begin{array}{l}2.11 \mathrm{mg} \text { prostaglandin } \mathrm{E}_{2} \text {, } \\
\text { intracervical }\end{array}$ & 1 & 40 & Mean Difference (IV, Fixed, 95\% CI) & $6.8[5.99,7.61]$ \\
\hline $\begin{array}{l}2.21 \mathrm{mg} \text { prostaglandin } \mathrm{E}_{2} \text {, } \\
\text { oral }\end{array}$ & 1 & 288 & Mean Difference (IV, Fixed, 95\% CI) & Not estimable \\
\hline
\end{tabular}




\begin{tabular}{lcccc} 
Outcome or subgroup title & $\begin{array}{c}\text { No. of } \\
\text { studies }\end{array}$ & $\begin{array}{c}\text { No. of } \\
\text { participants }\end{array}$ & Statistical method & Effect size \\
\hline $\begin{array}{l}\text { 1 Cervical dilation at procedure } \\
\text { start }\end{array}$ & 1 & 40 & Mean Difference (IV, Fixed, 95\% CI) & Not estimable \\
\hline
\end{tabular}

Comparison 7. Misoprostol dose: $400 \mu \mathrm{g}$ misoprostol versus $200 \mu \mathrm{g}$ misoprostol

\begin{tabular}{lcclc} 
Outcome or subgroup title & $\begin{array}{c}\text { No. of } \\
\text { studies }\end{array}$ & $\begin{array}{c}\text { No. of } \\
\text { participants }\end{array}$ & \multicolumn{1}{c}{ Statistical method } & Effect size \\
\hline $\begin{array}{l}\text { 1 Cervical dilation at procedure } \\
\text { start }\end{array}$ & 4 & & Mean Difference (IV, Fixed, 95\% CI) & Subtotals only \\
$\quad$ 1.1 Oral misoprostol & 2 & 632 & Mean Difference (IV, Fixed, 95\% CI) & $0.53[0.30,0.77]$ \\
1.2 Vaginal misoprostol & 2 & 137 & Mean Difference (IV, Fixed, 95\% CI) & $0.92[0.53,1.31]$ \\
1.3 Sublingual misoprostol & 1 & 120 & Mean Difference (IV, Fixed, 95\% CI) & $2.20[1.61,2.79]$ \\
2 Need for additional mechanical & 2 & 180 & Odds Ratio (M-H, Fixed, 95\% CI) & $0.04[0.02,0.10]$ \\
$\quad$ dilation & 1 & & & \\
2.1 Vaginal misoprostol & 1 & 120 & Odds Ratio (M-H, Fixed, 95\% CI) & $0.01[0.00,0.09]$ \\
2.2 Sublingual misoprostol & 2 & 180 & Odds Ratio (M-H, Fixed, 95\% CI) & $2.50[1.31,4.75]$ \\
3 Pain with cervical priming & 1 & 60 & Odds Ratio (M-H, Fixed, 95\% CI) & $8.11[1.61,40.77]$ \\
3.1 Vaginal misoprostol & 1 & 120 & Odds Ratio (M-H, Fixed, 95\% CI) & $1.84[0.89,3.80]$ \\
3.2 Sublingual misoprostol & 2 & 197 & Mean Difference (IV, Fixed, 95\% CI) & $-1.22[-1.72,-0.71]$ \\
4 Procedure length (minutes) & 1 & 77 & Mean Difference (IV, Fixed, 95\% CI) & $-0.30[-1.34,0.74]$ \\
$\quad$ 4.1 Vaginal misoprostol & 1 & 120 & Mean Difference (IV, Fixed, 95\% CI) & $-1.50[-2.08,-0.92]$ \\
$\quad$ 4.2 Sublingual misoprostol & & & & \\
\hline
\end{tabular}

Comparison 8. Interval between misoprostol application and procedure: 2 hours versus 3 hours

\begin{tabular}{lcclc} 
Outcome or subgroup title & $\begin{array}{c}\text { No. of } \\
\text { studies }\end{array}$ & $\begin{array}{c}\text { No. of } \\
\text { participants }\end{array}$ & Statistical method & Effect size \\
\hline $\begin{array}{l}\text { 1 Cervical dilation at procedure } \\
\text { start }\end{array}$ & 1 & 60 & Mean Difference (IV, Fixed, 95\% CI) & $1.5[1.42,1.58]$ \\
$\begin{array}{l}\text { Need for additional mechanical } \\
\text { dilation }\end{array}$ & 1 & 60 & Odds Ratio (M-H, Fixed, 95\% CI) & $0.01[0.00,0.08]$ \\
\begin{tabular}{l} 
3 Pain with cervical priming \\
\hline
\end{tabular} & 1 & 60 & Odds Ratio (M-H, Fixed, 95\% CI) & $0.10[0.02,0.39]$ \\
\hline
\end{tabular}




\begin{tabular}{|c|c|c|c|c|}
\hline Outcome or subgroup title & $\begin{array}{l}\text { No. of } \\
\text { studies }\end{array}$ & $\begin{array}{c}\text { No. of } \\
\text { participants }\end{array}$ & Statistical method & Effect size \\
\hline $\begin{array}{l}1 \text { Cervical dilation at procedure } \\
\text { start }\end{array}$ & 5 & & Mean Difference (IV, Fixed, 95\% CI) & Subtotals only \\
\hline $1.1400 \mu \mathrm{g}$ vaginal versus oral & 2 & 157 & Mean Difference (IV, Fixed, 95\% CI) & $0.50[0.13,0.87]$ \\
\hline $\begin{array}{l}1.2400 \mu \mathrm{g} \text { vaginal versus } \\
\text { sublingual }\end{array}$ & 3 & 1604 & Mean Difference (IV, Fixed, 95\% CI) & $-0.10[-0.19,-0.01]$ \\
\hline $\begin{array}{l}2 \text { Need for additional mechanical } \\
\text { dilation }\end{array}$ & 3 & & Odds Ratio (M-H, Fixed, 95\% CI) & Subtotals only \\
\hline $2.1400 \mu \mathrm{g}$ vaginal versus oral & 1 & 80 & Odds Ratio (M-H, Fixed, 95\% CI) & $0.47[0.08,2.75]$ \\
\hline $\begin{array}{l}2.2400 \mu \mathrm{g} \text { vaginal versus } \\
\text { sublingual }\end{array}$ & 2 & 1524 & Odds Ratio (M-H, Fixed, 95\% CI) & $1.41[1.15,1.73]$ \\
\hline $\begin{array}{l}3 \text { Side-effects: occurrence of } \\
\text { nausea }\end{array}$ & 6 & & Odds Ratio (M-H, Fixed, 95\% CI) & Subtotals only \\
\hline $3.1400 \mu \mathrm{g}$ vaginal versus oral & 2 & 157 & Odds Ratio (M-H, Fixed, 95\% CI) & $0.59[0.26,1.37]$ \\
\hline $\begin{array}{l}3.2400 \mu \mathrm{g} \text { vaginal versus } \\
\text { sublingual }\end{array}$ & 4 & 1678 & Odds Ratio (M-H, Fixed, 95\% CI) & $0.32[0.23,0.46]$ \\
\hline $\begin{array}{l}4 \text { Cervical dilation at procedure } \\
\text { start }\end{array}$ & 1 & 32 & Mean Difference (IV, Fixed, 95\% CI) & $0.5[-0.55,1.55]$ \\
\hline 5 Procedure length (minutes) & 4 & & Mean Difference (IV, Fixed, 95\% CI) & Subtotals only \\
\hline $5.1400 \mu \mathrm{g}$ vaginal versus oral & 2 & 157 & Mean Difference (IV, Fixed, 95\% CI) & $-0.23[-0.61,0.15]$ \\
\hline $\begin{array}{l}5.2400 \mu \mathrm{g} \text { vaginal versus } \\
\text { sublingual }\end{array}$ & 2 & 1524 & Mean Difference (IV, Fixed, 95\% CI) & $0.38[0.11,0.65]$ \\
\hline 6 Patient disatisfaction & 1 & 73 & Odds Ratio (M-H, Fixed, 95\% CI) & $0.10[0.01,1.97]$ \\
\hline
\end{tabular}

Comparison 10. Misoprostol versus gemeprost

\begin{tabular}{|c|c|c|c|c|}
\hline Outcome or subgroup title & $\begin{array}{l}\text { No. of } \\
\text { studies }\end{array}$ & $\begin{array}{c}\text { No. of } \\
\text { participants }\end{array}$ & Statistical method & Effect size \\
\hline $\begin{array}{l}1 \text { Cervical dilation at procedure } \\
\text { start }\end{array}$ & 3 & 342 & Mean Difference (IV, Fixed, 95\% CI) & $0.47[0.10,0.85]$ \\
\hline $\begin{array}{l}1.1400 \mu \mathrm{g} \text { misoprostol versus } \\
1 \mathrm{mg} \text { gemeprost }\end{array}$ & 2 & 154 & Mean Difference (IV, Fixed, 95\% CI) & $0.53[0.03,1.04]$ \\
\hline $\begin{array}{l}1.2200 \mu \mathrm{g} \text { misoprostol versus } \\
1 \mathrm{mg} \text { gemeprost }\end{array}$ & 1 & 188 & Mean Difference (IV, Fixed, 95\% CI) & $0.40[-0.16,0.96]$ \\
\hline $\begin{array}{l}2 \text { Side-effects of } 200 \mu \mathrm{g} \\
\text { misoprostol versus gemeprost }\end{array}$ & 1 & 564 & Odds Ratio (M-H, Fixed, 95\% CI) & $0.35[0.18,0.68]$ \\
\hline 2.1 Nausea & 1 & 188 & Odds Ratio (M-H, Fixed, 95\% CI) & $0.41[0.17,1.01]$ \\
\hline 2.2 Vomiting & 1 & 188 & Odds Ratio (M-H, Fixed, 95\% CI) & $0.35[0.09,1.35]$ \\
\hline 2.3 Diarrhea & 1 & 188 & Odds Ratio (M-H, Fixed, 95\% CI) & $0.23[0.05,1.11]$ \\
\hline $\begin{array}{l}3 \text { Side-effects of } 400 \text { misoprostol } \\
\text { versus gemeprost }\end{array}$ & 1 & 128 & Odds Ratio (M-H, Fixed, 95\% CI) & $0.47[0.11,1.98]$ \\
\hline 3.1 Nausea & 1 & 64 & Odds Ratio (M-H, Fixed, 95\% CI) & $0.36[0.06,2.01]$ \\
\hline 3.2 Vomiting & 1 & 64 & Odds Ratio (M-H, Fixed, 95\% CI) & $1.0[0.06,16.71]$ \\
\hline
\end{tabular}


Comparison 11. Misoprostol versus mifepristone

\begin{tabular}{|c|c|c|c|c|}
\hline Outcome or subgroup title & $\begin{array}{l}\text { No. of } \\
\text { studies }\end{array}$ & $\begin{array}{c}\text { No. of } \\
\text { participants }\end{array}$ & Statistical method & Effect size \\
\hline $\begin{array}{l}1 \text { Cervical dilation at procedure } \\
\text { start }\end{array}$ & 2 & 90 & Mean Difference (IV, Fixed, 95\% CI) & $-0.79[-1.29,-0.30]$ \\
\hline $\begin{array}{l}1.1800 \mu \mathrm{g} \text { misoprostol versus } \\
200 \mathrm{mg} \text { mifepristone }\end{array}$ & 1 & 60 & Mean Difference (IV, Fixed, 95\% CI) & $-0.70[-1.30,-0.10]$ \\
\hline $\begin{array}{l}1.2600 \mu \mathrm{g} \text { misoprostol versus } \\
400 \mathrm{mg} \text { mifepristone (divided } \\
\text { doses) }\end{array}$ & 1 & 30 & Mean Difference (IV, Fixed, 95\% CI) & $-1.0[-1.89,-0.11]$ \\
\hline 2 Side-effects: nausea and vomiting & 2 & 90 & Odds Ratio (M-H, Fixed, 95\% CI) & $0.75[0.17,3.33]$ \\
\hline $\begin{array}{l}2.1800 \mu \mathrm{g} \text { misoprostol versus } \\
200 \mu \mathrm{g} \text { mifepristone }\end{array}$ & 1 & 60 & Odds Ratio (M-H, Fixed, 95\% CI) & $0.19[0.01,4.06]$ \\
\hline $\begin{array}{l}2.2600 \mu \mathrm{g} \text { misoprostol versus } \\
400 \mathrm{mg} \text { mifepristone (divided } \\
\text { doses) }\end{array}$ & 1 & 30 & Odds Ratio (M-H, Fixed, 95\% CI) & $1.63[0.23,11.46]$ \\
\hline
\end{tabular}

Comparison 12. Misoprostol versus laminaria

\begin{tabular}{lcccc} 
Outcome or subgroup title & $\begin{array}{c}\text { No. of } \\
\text { studies }\end{array}$ & $\begin{array}{c}\text { No. of } \\
\text { participants }\end{array}$ & \multicolumn{1}{c}{ Statistical method } & Effect size \\
\hline $\begin{array}{l}\text { 1 Need for additional mechanical } \\
\text { dilation }\end{array}$ & 2 & 131 & Odds Ratio (M-H, Fixed, 95\% CI) & $1.04[0.48,2.26]$ \\
$1.1200 \mu \mathrm{g}$ misoprostol & 1 & 70 & Odds Ratio (M-H, Fixed, 95\% CI) & $1.18[0.43,3.25]$ \\
$1.2400 \mu \mathrm{g}$ misoprostol & 1 & 61 & Odds Ratio (M-H, Fixed, 95\% CI) & $0.88[0.27,2.90]$ \\
2 Procedure length (minutes) & 1 & 70 & Mean Difference (IV, Fixed, 95\% CI) & $-0.10[-1.09,0.89]$ \\
3 Patient disatisfaction & 1 & 70 & Odds Ratio (M-H, Fixed, 95\% CI) & $0.31[0.12,0.84]$ \\
\hline
\end{tabular}

Comparison 13. Misoprostol versus prostaglandin $\mathbf{F}_{2 \alpha}$

\begin{tabular}{|c|c|c|c|c|}
\hline Outcome or subgroup title & $\begin{array}{l}\text { No. of } \\
\text { studies }\end{array}$ & $\begin{array}{c}\text { No. of } \\
\text { participants }\end{array}$ & Statistical method & Effect size \\
\hline $\begin{array}{l}1 \text { Need for additional mechanical } \\
\text { dilation }\end{array}$ & 1 & 60 & Odds Ratio (M-H, Fixed, 95\% CI) & $0.48[0.16,1.41]$ \\
\hline $\begin{array}{l}2 \text { Cervical dilation at procedure } \\
\text { start }\end{array}$ & 1 & 60 & Mean Difference (IV, Fixed, 95\% CI) & $1.80[1.04,2.56]$ \\
\hline 3 Side-effects: nausea and vomiting & 1 & 60 & Odds Ratio (M-H, Fixed, 95\% CI) & $0.14[0.02,1.23]$ \\
\hline 4 Procedure length (minutes) & 1 & 60 & Mean Difference (IV, Fixed, 95\% CI) & $0.20[-0.76,1.16]$ \\
\hline
\end{tabular}


Comparison 14. Gemeprost $1 \mathrm{mg}$ versus Lamicel

\begin{tabular}{lcccc} 
Outcome or subgroup title & $\begin{array}{c}\text { No. of } \\
\text { studies }\end{array}$ & $\begin{array}{c}\text { No. of } \\
\text { participants }\end{array}$ & Statistical method & Effect size \\
\hline $\begin{array}{l}\text { 1 Need for additional mechanical } \\
\text { dilation }\end{array}$ & 2 & 153 & Odds Ratio (M-H, Fixed, 95\% CI) & $0.86[0.38,1.95]$ \\
$\begin{array}{l}\text { Side-effects } \\
\text { 2.1 Nausea }\end{array}$ & 2 & & Odds Ratio (M-H, Fixed, 95\% CI) & $\begin{array}{l}\text { Subtotals only } \\
\text { 2.2 Pre-operative pain }\end{array}$ \\
\hline
\end{tabular}

Comparison 15. Gemeprost versus Dilapan

\begin{tabular}{lcccc} 
Outcome or subgroup title & $\begin{array}{c}\text { No. of } \\
\text { studies }\end{array}$ & $\begin{array}{c}\text { No. of } \\
\text { participants }\end{array}$ & Statistical method & Effect size \\
\hline $\begin{array}{l}\text { 1 Need for additional mechanical } \\
\text { dilation }\end{array}$ & 2 & 83 & Odds Ratio (M-H, Fixed, 95\% CI) & $0.87[0.32,2.36]$ \\
$\begin{array}{l}\text { Side-effects } \\
\text { 2.1 Nausea }\end{array}$ & 2 & & Odds Ratio (M-H, Fixed, 95\% CI) & Subtotals only \\
2.2 Pre-operative pain & 2 & 83 & Odds Ratio (M-H, Fixed, 95\% CI) & $0.50[0.10,2.51]$ \\
& 2 & 83 & Odds Ratio (M-H, Fixed, 95\% CI) & $1.02[0.37,2.84]$ \\
\hline
\end{tabular}

\section{Comparison 16. Gemeprost versus laminaria}

\begin{tabular}{lcccc} 
Outcome or subgroup title & $\begin{array}{c}\text { No. of } \\
\text { studies }\end{array}$ & $\begin{array}{c}\text { No. of } \\
\text { participants }\end{array}$ & Statistical method & Effect size \\
\hline $\begin{array}{l}1 \text { Need for additional mechanical } \\
\text { dilation }\end{array}$ & 1 & 250 & Odds Ratio (M-H, Fixed, 95\% CI) & $0.56[0.29,1.07]$ \\
$\begin{array}{l}\text { Cervical dilation at procedure } \\
\quad \text { start }\end{array}$ & 1 & 250 & Mean Difference (IV, Fixed, 95\% CI) & $0.5[0.05,0.95]$ \\
3 Side-effects: nausea and vomiting & 1 & 250 & Odds Ratio (M-H, Fixed, 95\% CI) & $18.16[1.04,318.09]$ \\
\hline
\end{tabular}


Comparison 17. Gemeprost versus prostaglandin $\mathbf{F}_{2 \alpha}$

\begin{tabular}{lcccc} 
Outcome or subgroup title & $\begin{array}{c}\text { No. of } \\
\text { studies }\end{array}$ & $\begin{array}{c}\text { No. of } \\
\text { participants }\end{array}$ & Statistical method & Effect size \\
\hline $\begin{array}{l}1 \text { Need for additional mechanical } \\
\text { dilation }\end{array}$ & 1 & 252 & Odds Ratio (M-H, Fixed, 95\% CI) & $0.31[0.15,0.66]$ \\
$\begin{array}{l}\text { Cervical dilation at procedure } \\
\text { start }\end{array}$ & 1 & 252 & Mean Difference (IV, Fixed, 95\% CI) & $0.90[0.42,1.38]$ \\
\begin{tabular}{l}
3 Side-effects: nausea and vomiting \\
\hline
\end{tabular} & 1 & 252 & Odds Ratio (M-H, Fixed, 95\% CI) & $1.67[0.53,5.25]$ \\
\hline
\end{tabular}

\section{Comparison 18. Dose of mifepristone}

\begin{tabular}{lcccc} 
Outcome or subgroup title & $\begin{array}{c}\text { No. of } \\
\text { studies }\end{array}$ & $\begin{array}{c}\text { No. of } \\
\text { participants }\end{array}$ & Statistical method & Effect size \\
\hline $\begin{array}{l}1 \text { Need for additional mechanical } \\
\text { dilation }\end{array}$ & 1 & 102 & Odds Ratio (M-H, Fixed, 95\% CI) & $0.74[0.12,4.62]$ \\
$\begin{array}{l}\text { Cervical dilation at procedure } \\
\text { start }\end{array}$ & 1 & 102 & Mean Difference (IV, Fixed, 95\% CI) & Not estimable \\
\hline
\end{tabular}

Comparison 19. Laminaria versus prostaglandin $F_{2 \alpha}$

\begin{tabular}{lcccc} 
Outcome or subgroup title & $\begin{array}{c}\text { No. of } \\
\text { studies }\end{array}$ & $\begin{array}{c}\text { No. of } \\
\text { participants }\end{array}$ & Statistical method & Effect size \\
\hline $\begin{array}{l}\text { 1 Cervical dilation at procedure } \\
\text { start }\end{array}$ & 1 & 40 & Mean Difference (IV, Fixed, 95\% CI) & Not estimable \\
$\begin{array}{l}2 \text { Unplanned expulsion prior to } \\
\text { procedure }\end{array}$ & 1 & 40 & Odds Ratio (M-H, Fixed, 95\% CI) & $0.07[0.00,1.34]$ \\
\hline
\end{tabular}

Comparison 20. Laminaria versus sulprostone

\begin{tabular}{|c|c|c|c|c|}
\hline Outcome or subgroup title & $\begin{array}{l}\text { No. of } \\
\text { studies }\end{array}$ & $\begin{array}{c}\text { No. of } \\
\text { participants }\end{array}$ & Statistical method & Effect size \\
\hline $\begin{array}{l}1 \text { Cervical dilation at procedure } \\
\text { start }\end{array}$ & 1 & 251 & Mean Difference (IV, Fixed, 95\% CI) & $-0.80[-1.27,-0.33]$ \\
\hline $\begin{array}{l}2 \text { Need for additional mechanical } \\
\text { dilation }\end{array}$ & 1 & 251 & Odds Ratio (M-H, Fixed, 95\% CI) & $2.38[1.26,4.47]$ \\
\hline 3 Side-effects: nausea and vomiting & 1 & 251 & Odds Ratio (M-H, Fixed, 95\% CI) & $0.02[0.00,0.39]$ \\
\hline
\end{tabular}




\begin{tabular}{lcccc} 
Outcome or subgroup title & $\begin{array}{c}\text { No. of } \\
\text { studies }\end{array}$ & $\begin{array}{c}\text { No. of } \\
\text { participants }\end{array}$ & Statistical method & Effect size \\
\hline $\begin{array}{l}\text { 1 Cervical dilation at procedure } \\
\text { start }\end{array}$ & 1 & 249 & Mean Difference (IV, Fixed, 95\% CI) & $-0.40[-0.81,0.01]$ \\
$\begin{array}{c}\text { Need for additional mechanical } \\
\text { dilation }\end{array}$ & 1 & 249 & Odds Ratio (M-H, Fixed, 95\% CI) & $1.81[0.95,3.48]$ \\
\begin{tabular}{l}
3 Side-effects: nausea and vomiting \\
\hline
\end{tabular} & 1 & 249 & Odds Ratio (M-H, Fixed, 95\% CI) & $0.03[0.00,0.51]$ \\
\hline
\end{tabular}

Comparison 22. Sulprostone versus sulprostone (intracervical doses)

\begin{tabular}{lcccc} 
Outcome or subgroup title & $\begin{array}{c}\text { No. of } \\
\text { studies }\end{array}$ & $\begin{array}{c}\text { No. of } \\
\text { participants }\end{array}$ & Statistical method & Effect size \\
\hline $\begin{array}{l}\text { 1 Need for additional mechanical } \\
\quad \text { dilation }\end{array}$ & 1 & 40 & Odds Ratio (M-H, Fixed, 95\% CI) & Not estimable \\
$\begin{array}{l}2 \text { Side-effects: nausea and vomiting } \\
\begin{array}{l}\text { Unplanned expulsion prior to } \\
\quad\end{array}\end{array}$ & 2 & 60 & Odds Ratio (M-H, Fixed, 95\% CI) & $0.79[0.21,3.04]$ \\
$\quad$ procedure & 60 & Odds Ratio (M-H, Fixed, 95\% CI) & $0.04[0.00,0.37]$ \\
\hline
\end{tabular}

\section{Comparison 23. Sulprostone versus sulprostone (intramuscular doses)}

\begin{tabular}{lcccc} 
Outcome or subgroup title & $\begin{array}{c}\text { No. of } \\
\text { studies }\end{array}$ & $\begin{array}{c}\text { No. of } \\
\text { participants }\end{array}$ & Statistical method & Effect size \\
\hline $\begin{array}{l}\text { 1 Need for additional mechanical } \\
\quad \text { dilation }\end{array}$ & 1 & 200 & Odds Ratio (M-H, Fixed, 95\% CI) & $0.72[0.24,2.15]$ \\
$\begin{array}{l}2 \text { Side-effects: nausea and vomiting } \\
\text { Unplanned expulsion prior to }\end{array}$ & 1 & 200 & Odds Ratio (M-H, Fixed, 95\% CI) & $0.13[0.04,0.44]$ \\
$\quad$\begin{tabular}{l} 
procedure \\
\hline
\end{tabular} & 1 & 200 & Odds Ratio (M-H, Fixed, 95\% CI) & $0.34[0.01,8.36]$ \\
\end{tabular}

Comparison 24. Prostaglandin $\mathbf{E}_{2}$ versus prostaglandin $\mathbf{F}_{2 \alpha}$

\begin{tabular}{|c|c|c|c|c|}
\hline Outcome or subgroup title & $\begin{array}{l}\text { No. of } \\
\text { studies }\end{array}$ & $\begin{array}{c}\text { No. of } \\
\text { participants }\end{array}$ & Statistical method & Effect size \\
\hline $\begin{array}{l}1 \text { Need for additional mechanical } \\
\text { dilation }\end{array}$ & 1 & 299 & Odds Ratio (M-H, Fixed, 95\% CI) & $12.9[7.22,23.05]$ \\
\hline 2 Side-effects: nausea and vomiting & 1 & 299 & Odds Ratio (M-H, Fixed, 95\% CI) & $0.17[0.04,0.78]$ \\
\hline $\begin{array}{l}3 \text { Unplanned expulsion prior to } \\
\text { procedure }\end{array}$ & 1 & 299 & Odds Ratio (M-H, Fixed, 95\% CI) & Not estimable \\
\hline
\end{tabular}


Comparison 25. Lamicel versus synthetic sponge without $\mathrm{MgSO}_{4}$

\begin{tabular}{lcccc} 
Outcome or subgroup title & $\begin{array}{c}\text { No. of } \\
\text { studies }\end{array}$ & $\begin{array}{c}\text { No. of } \\
\text { participants }\end{array}$ & Statistical method & Effect size \\
\hline $\begin{array}{l}1 \text { Unplanned expulsion prior to } \\
\text { procedure }\end{array}$ & 1 & 41 & Odds Ratio (M-H, Fixed, 95\% CI) & $3.65[0.14,94.97]$ \\
\hline
\end{tabular}

\section{Analysis I.I. Comparison I Misoprostol versus placebo, Outcome I Cervical dilation at procedure start.}

Review: Cervical preparation for first trimester surgical abortion

Comparison: I Misoprostol versus placebo

Outcome: I Cervical dilation at procedure start

Study or subgroup Misoprostol Placebor Mean Mean

N Mean(SD) N Mean(SD) IV,Fixed,95\% Cl IV,Fixed,95\% Cl

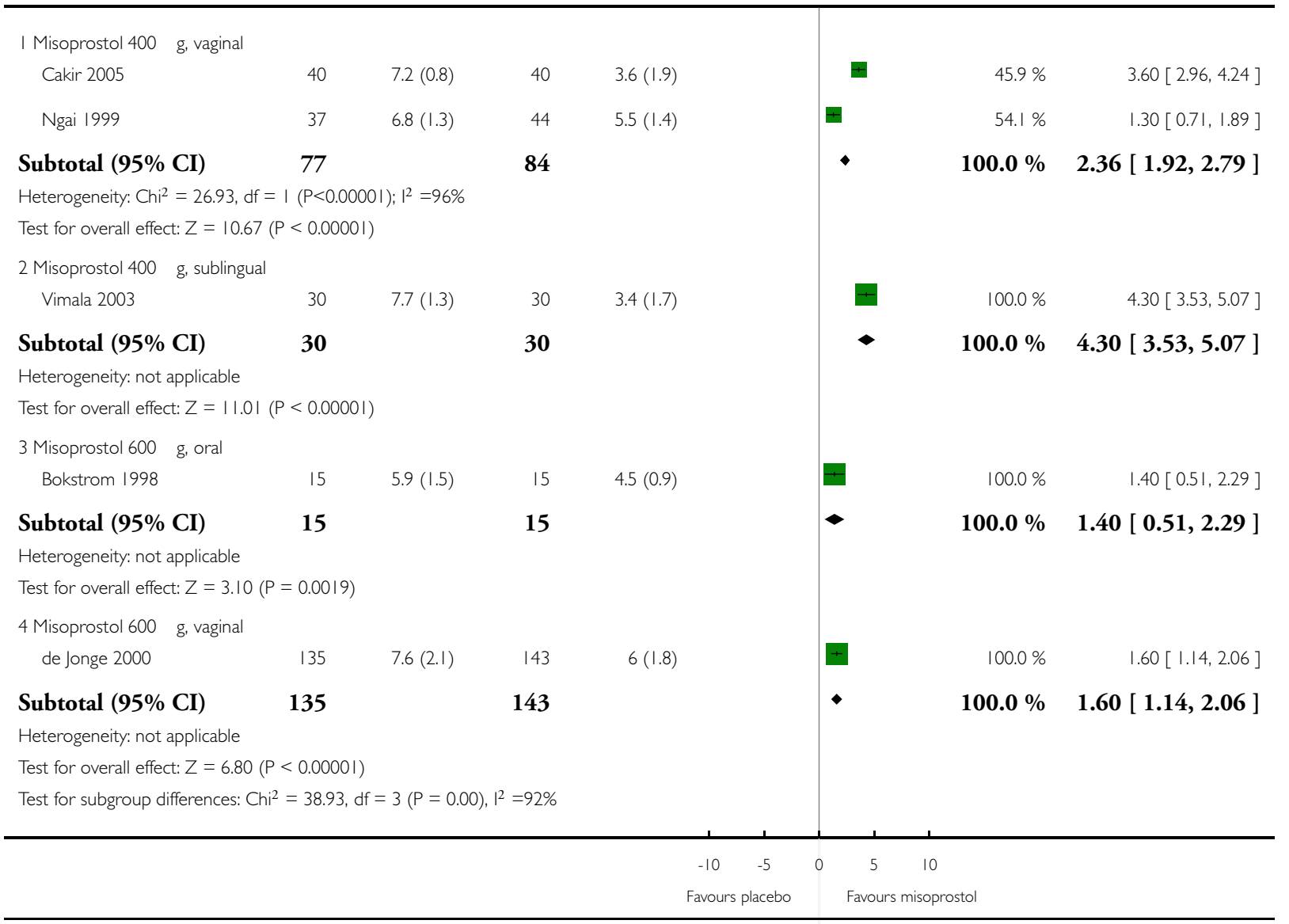

Cervical preparation for first trimester surgical abortion (Review)

Copyright $\odot 2010$ The Cochrane Collaboration. Published by John Wiley \& Sons, Ltd. 
Analysis I.2. Comparison I Misoprostol versus placebo, Outcome 2 Side-effects: occurrence of nausea.

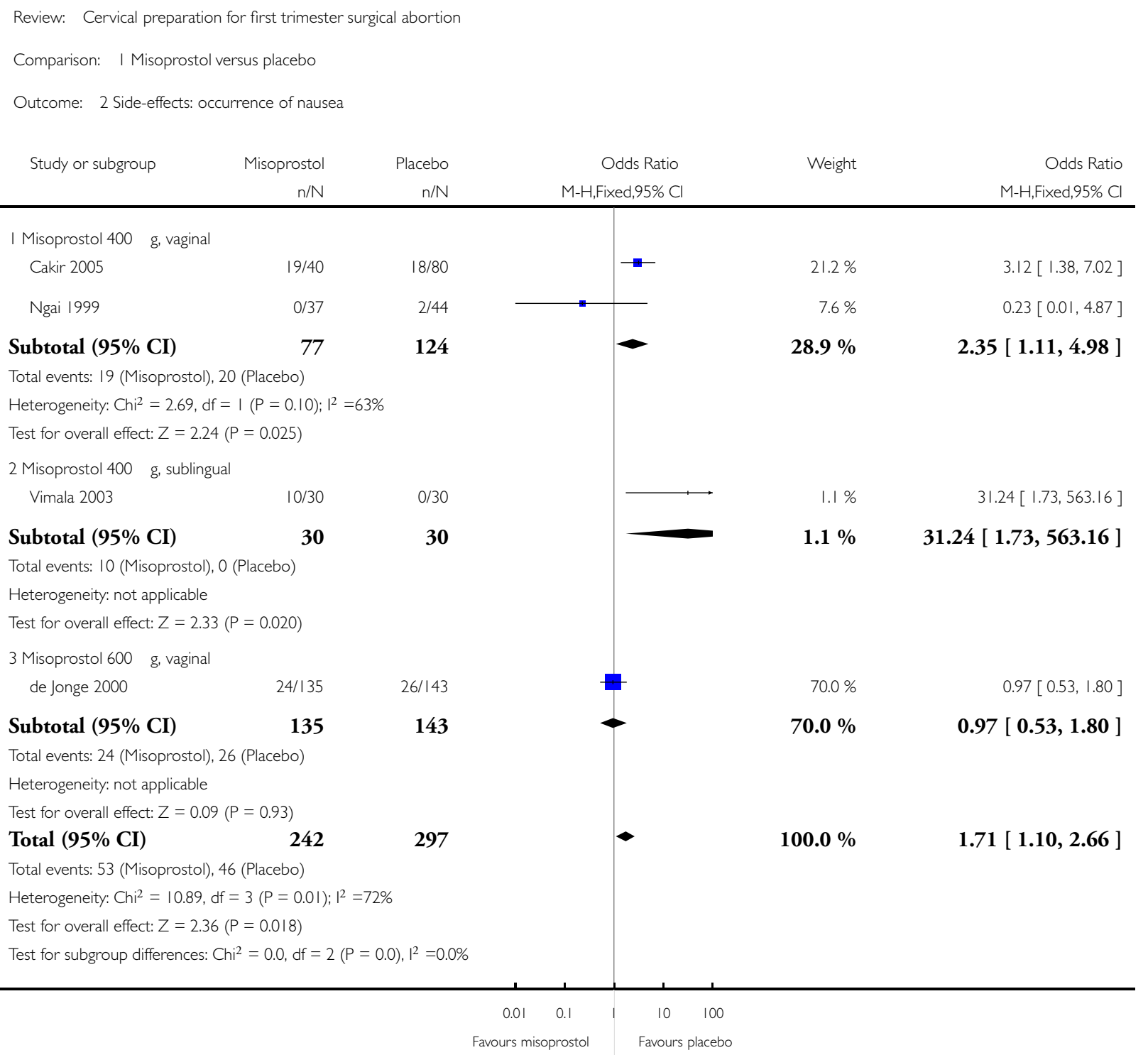


Analysis I.3. Comparison I Misoprostol versus placebo, Outcome 3 Procedure length (minutes).

Review: Cervical preparation for first trimester surgical abortion

Comparison: I Misoprostol versus placebo

Outcome: 3 Procedure length (minutes)

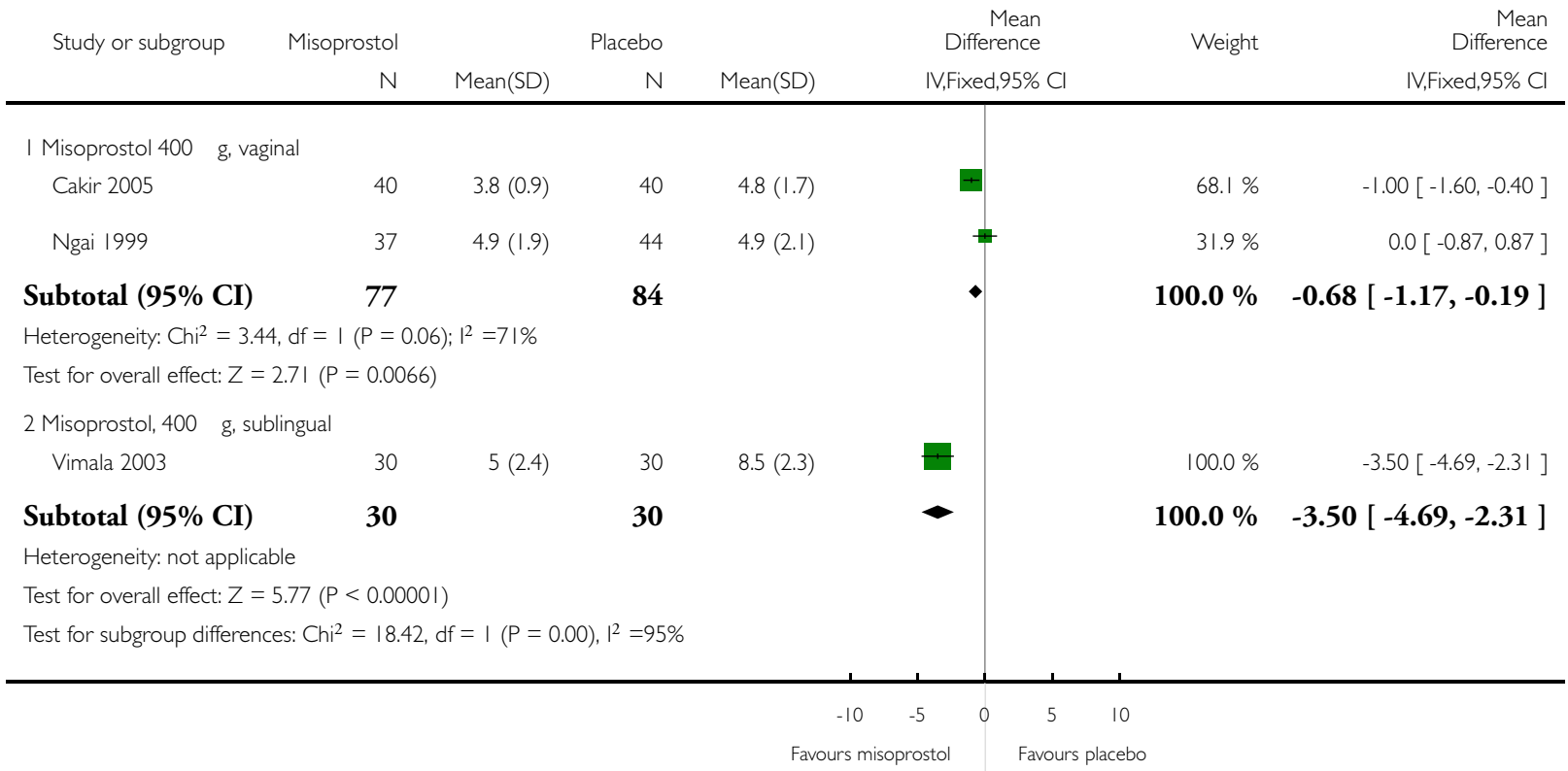


Analysis 2.I. Comparison 2 Gemeprost I mg versus placebo, Outcome I Need for additional mechanical dilation.

Review: Cervical preparation for first trimester surgical abortion

Comparison: 2 Gemeprost I mg versus placebo

Outcome: I Need for additional mechanical dilation

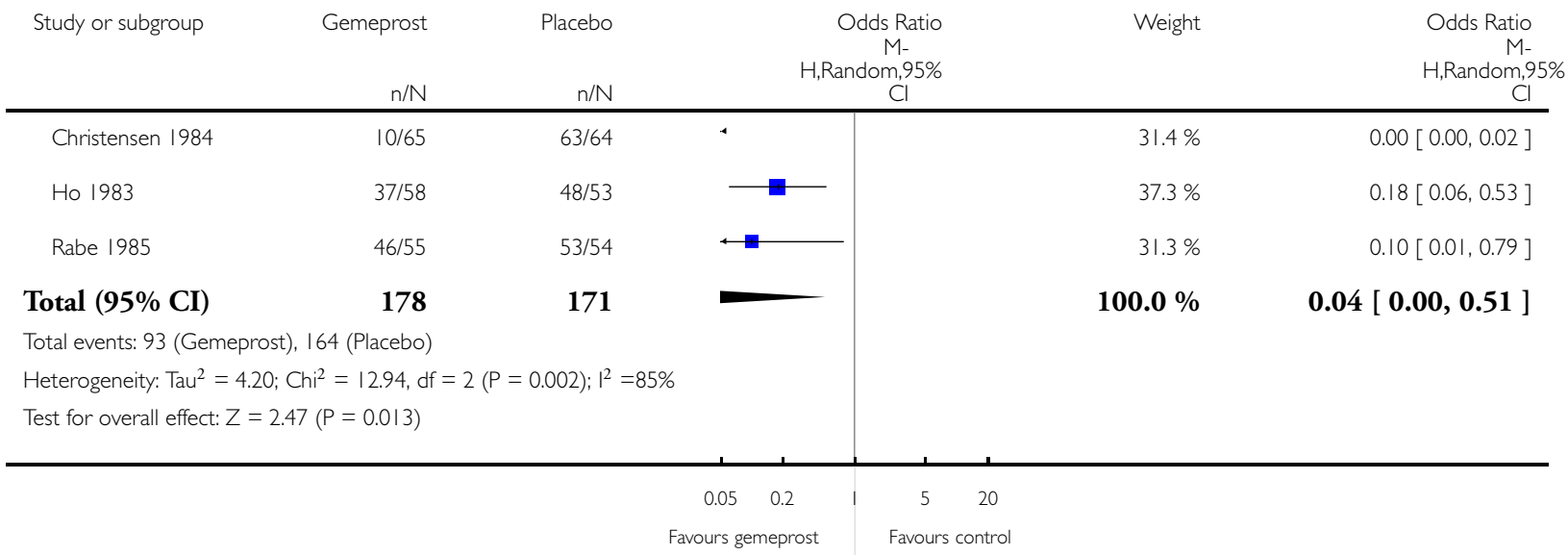




\section{Analysis 3.I. Comparison 3 Mifepristone versus placebo, Outcome I Need for additional mechanical}

dilation.

Review: Cervical preparation for first trimester surgical abortion

Comparison: 3 Mifepristone versus placebo

Outcome: I Need for additional mechanical dilation

Study or subgroup Mifepristone Control Odds Ratio Ratio

$\mathrm{n} / \mathrm{N} \quad \mathrm{n} / \mathrm{N}$

$\mathrm{M}-\mathrm{H}$, Fixed,95\% Cl

$\mathrm{M}-\mathrm{H}$, Fixed,95\% Cl

I 100 mg mifepristone

WHO 1990 (I)

$51 / 54$

$52 / 54$

Subtotal (95\% CI)

54

54

Total events: 5 I (Mifepristone), 52 (Control)

Heterogeneity: not applicable

Test for overall effect: $Z=0.45(P=0.65)$

2200 mg mifepristone

Bokstrom 1998

Subtotal (95\% CI)

Total events: 6 (Mifepristone), 8 (Control)

Heterogeneity: not applicable

Test for overall effect: $Z=0.73(P=0.47)$

3600 mg mifepristone

Gupta 1990

\begin{tabular}{l|l}
$\longrightarrow$ & \\
\hline
\end{tabular}

$17.5 \%$ $0.65[0.10,4.08]$

Subtotal (95\% CI)

Total events: 4 (Mifepristone), 12 (Control)

Heterogeneity: not applicable

Test for overall effect: $Z=2.75(P=0.0059)$

Total (95\% CI)

Total events: 6I (Mifepristone), 72 (Control)

Heterogeneity: $\mathrm{Chi}^{2}=3.32, \mathrm{df}=2(\mathrm{P}=0.19) ; \mathrm{I}^{2}=40 \%$

Test for overall effect: $Z=2.38(P=0.017)$

Test for subgroup differences: $\mathrm{Chi}^{2}=0.0, \mathrm{df}=2(\mathrm{P}=0.0), \mathrm{I}^{2}=0.0 \%$

\section{4}

$29.1 \%$

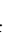
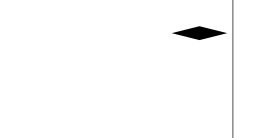

$0.58[0.14,2.48]$

$0.65[0.10,4.08$ ]

$0.58[0.14,2.48]$

$.58[0.14,2.48]$

.09 $[0.02,0.50]$

$0.33[0.13,0.82]$

\section{$\begin{array}{ccccc}0.01 & 0.1 & 1 & 10 & 100 \\ \text { Favours control } & & \text { Favours mifepristone }\end{array}$}

(I) 100 mg given 24 and 12 hours prior to procedure 


\section{Analysis 3.2. Comparison 3 Mifepristone versus placebo, Outcome 2 Cervical dilation at procedure start.}

Review: Cervical preparation for first trimester surgical abortion

Comparison: 3 Mifepristone versus placebo

Outcome: 2 Cervical dilation at procedure start

\section{Study or subgroup \\ Mifepristone}

N

Placebo

N

Mean(SD)

Mean
Difference

IV,Fixed,95\% C

I 100 mg mifepristone

WHO 1990

54

$6.6(1.9)$

54

54

Subtotal (95\% CI)

Heterogeneity: not applicable

Test for overall effect: $Z=3.73(P=0.00019)$

2200 mg mifepristone

Bokstrom 1998

$15 \quad 6.9(0.9)$

Durlot 1988

32

$5.5(1.9)$

15

32

\section{7}

Heterogeneity: $\mathrm{Chi}^{2}=3.55, \mathrm{df}=\mathrm{I}(\mathrm{P}=0.06) ; \mathrm{I}^{2}=72 \%$

Test for overall effect: $Z=7.81(P<0.00001)$

$3600 \mathrm{mg}$ mifepristone

$$
\text { Gupta } 1990
$$

$$
5(0)
$$

15

Heterogeneity: not applicable

Test for overall effect: not applicable

Total (95\% CI)

116

116

Heterogeneity: $\mathrm{Chi}^{2}=5.38, \mathrm{df}=2(P=0.07) ; \mathrm{I}^{2}=63 \%$

Test for overall effect: $Z=8.55(P<0.0000 \mathrm{I})$

Test for subgroup differences: $\mathrm{Chi}^{2}=1.83, \mathrm{df}=\mathrm{I}(\mathrm{P}=0.18), \mathrm{I}^{2}=45 \%$

54

$5.2(2)$

$4.5(0.9)$

$4.1(1.4)$

47

15

15

$4.5(0.9)$
$4.1(1.4)$

2)
4)

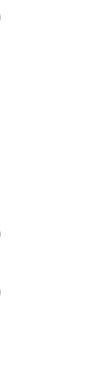

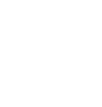

\section{$+$ \\ $\bullet$}

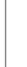

$+$

$+$

$\bullet$

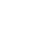

$26.0 \%$

$32.1 \% \quad 1.40[0.66,2.14]$

$32.1 \%$

$1.40[0.66,2.14$ ]

15

Not estimable

Not estimable

\section{$3(0)$}

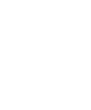

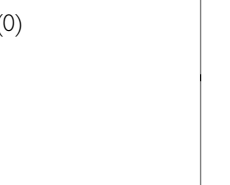

-

$100.0 \% \quad 1.82[1.40,2.24]$

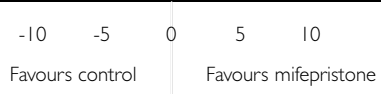




\section{Analysis 4.I. Comparison 4 Prostaglandin F2 $\alpha$ versus placebo, Outcome I Need for additional mechanical}

dilation.

Review: Cervical preparation for first trimester surgical abortion

Comparison: 4 Prostaglandin $\mathrm{F}_{2} \mathrm{a}$ versus placebo

Outcome: I Need for additional mechanical dilation

\begin{tabular}{|c|c|c|c|c|c|c|c|c|}
\hline \multirow{2}{*}{$\begin{array}{l}\text { Study or subgroup } \\
\text { Heinzl I98I (I) }\end{array}$} & \multirow{2}{*}{$\frac{\text { Prostaglandin F }}{20 / 149}$} & \multirow{2}{*}{$\begin{array}{r}\text { Placebo } \\
\text { n/N }\end{array}$} & \multicolumn{4}{|c|}{$\begin{array}{c}\text { Odds Ratio } \\
\text { M-H,Fixed,95\% Cl }\end{array}$} & Weight & $\begin{array}{r}\text { Odds Ratio } \\
\text { M-H,Fixed,95\% Cl}\end{array}$ \\
\hline & & & & & & & $100.0 \%$ & $0.02[0.01,0.04]$ \\
\hline Total $(95 \% \mathrm{CI})$ & 149 & 138 & 4 & & & & $100.0 \%$ & $0.02[0.01,0.04]$ \\
\hline \multicolumn{9}{|c|}{ Total events: 20 (Prostaglandin $F_{2 \alpha}$ ), 124 (Placebo) } \\
\hline \multicolumn{9}{|c|}{ Heterogeneity: not applicable } \\
\hline \multicolumn{9}{|c|}{ Test for overall effect: $Z=10.92(P<0.0000 \mid)$} \\
\hline \multicolumn{9}{|c|}{ Test for subgroup differences: Not applicable } \\
\hline & & & 0.01 & 0.1 & 10 & 100 & & \\
\hline
\end{tabular}

( I) Data from vaginal application of $2.5 \mathrm{mg}$ prostaglandin 
Analysis 5.I. Comparison 5 Prostaglandin E2 versus placebo, Outcome I Need for additional mechanical dilation.

Review: Cervical preparation for first trimester surgical abortion

Comparison: 5 Prostaglandin $E_{2}$ versus placebo

Outcome: I Need for additional mechanical dilation

Study or subgroup Prostaglandin $\mathrm{E}_{2}$

Control

$\mathrm{n} / \mathrm{N}$

Odds Ratio

Weight

Odds Ratio

$\mathrm{n} / \mathrm{N}$

M-H,Fixed,95\% Cl

M-H,Fixed,95\% Cl

I I mg prostaglandin $E_{2}$, intracervical

Shalev 1988

$1 / 20$

$20 / 20$

$\longleftarrow$

$100.0 \%$

$0.00[0.00,0.05]$

Subtotal (95\% CI)

20

20

$-$

$100.0 \%$

$0.00[0.00,0.05]$

Total events: I (Prostaglandin E2), 20 (Control)

Heterogeneity: not applicable

Test for overall effect: $Z=3.77(P=0.00016)$

225 g 15 methyl PGE2 methyl ester, extra-amniotic

$$
\text { Cheng } 1975
$$

$$
3 / 25
$$

Subtotal (95\% CI)

25

Total events: 3 (Prostaglandin E2), 25 (Control)

Heterogeneity: not applicable

Test for overall effect: $Z=3.76(P=0.00017)$

3 I mg PGE 2 , oral

$$
\text { Heinzl } 1981
$$

Subtotal (95\% CI)

150

Total events: 100 (Prostaglandin E2), 124 (Control)

Heterogeneity: not applicable

Test for overall effect: $Z=4.50(P<0.0000 \mathrm{I})$

$40.5 \mathrm{mg}$ prostaglandin $E_{2}$

$$
\text { Osmers } 1990
$$

Subtotal (95\% CI)

Total events: 4 (Prostaglandin E2), 17 (Control)

Heterogeneity: not applicable

Test for overall effect: $Z=3.48(P=0.0005 \mathrm{I})$

$124 / 138$

138

(3)

$100.0 \%$

$0.00[0.00,0.06]$

$100.0 \%$

$0.23[0.12,0.43]$

$100.0 \%$

$0.23[0.12,0.43]$

$100.0 \%$

$0.09[0.02,0.35]$

$100.0 \%$

$0.09[0.02,0.35]$
25

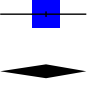




\section{Analysis 5.2. Comparison 5 Prostaglandin E2 versus placebo, Outcome 2 Cervical dilation at procedure}

start.

Review: Cervical preparation for first trimester surgical abortion

Comparison: 5 Prostaglandin $\mathrm{E}_{2}$ versus placebo

Outcome: 2 Cervical dilation at procedure start

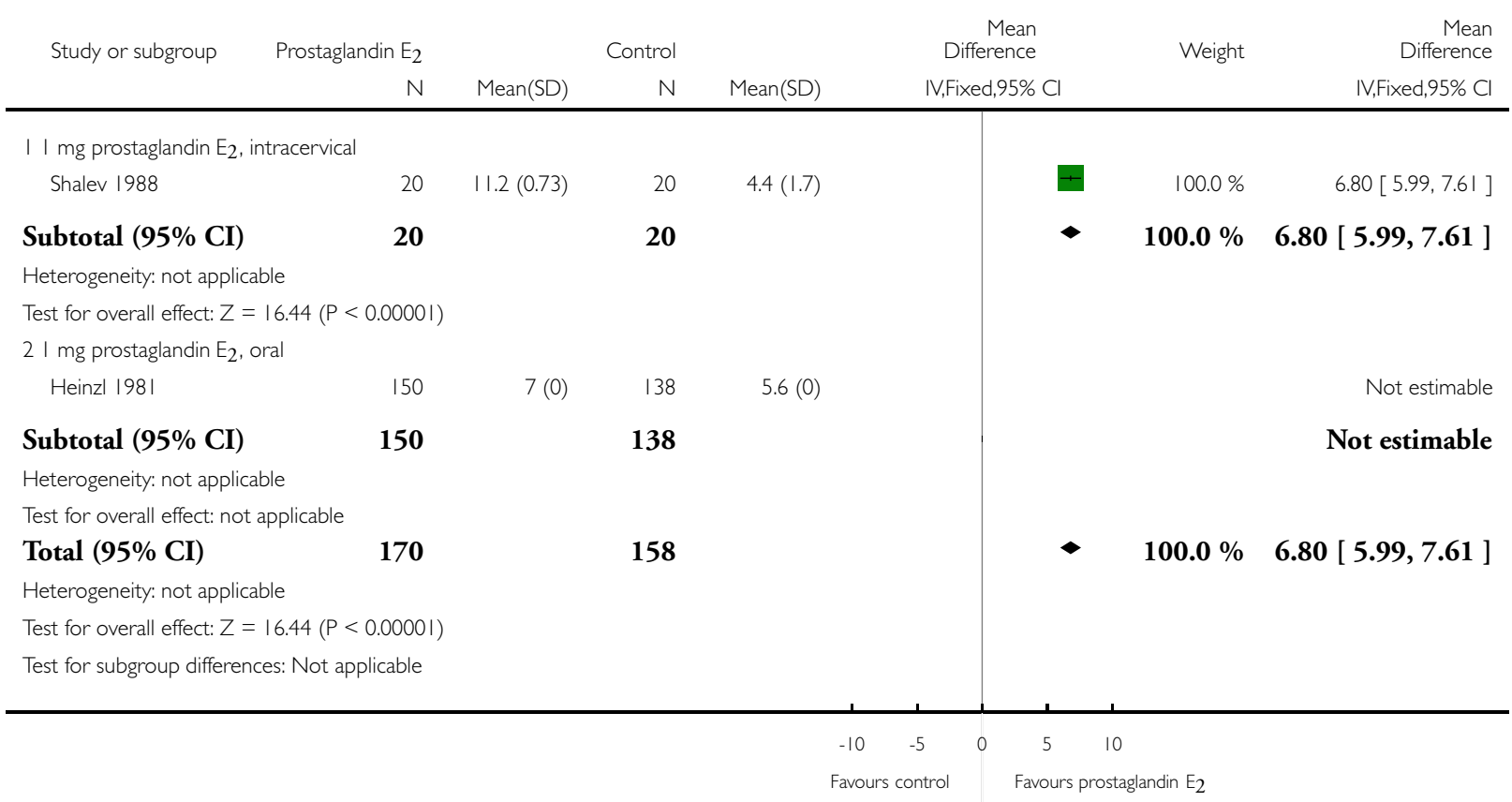


Analysis 6.1. Comparison 6 Osmotic dilators versus placebo, Outcome I Cervical dilation at procedure start.

Review: Cervical preparation for first trimester surgical abortion

Comparison: 6 Osmotic dilators versus placebo

Outcome: I Cervical dilation at procedure start

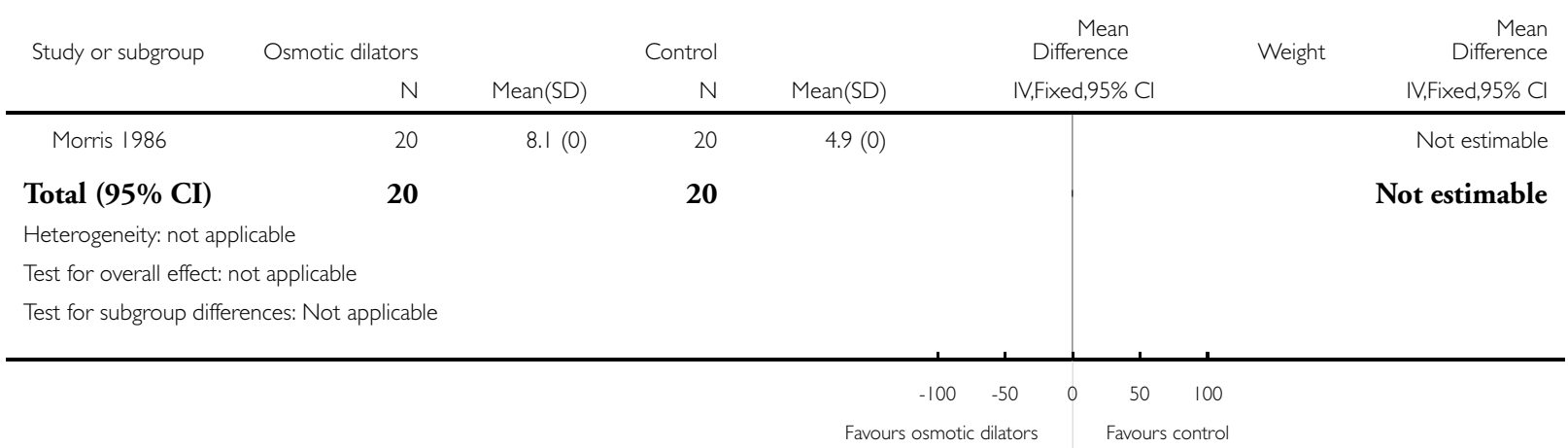




\section{Analysis 7.I. Comparison 7 Misoprostol dose: $400 \mu \mathrm{g}$ misoprostol versus $200 \mu \mathrm{g}$ misoprostol, Outcome I Cervical dilation at procedure start.}

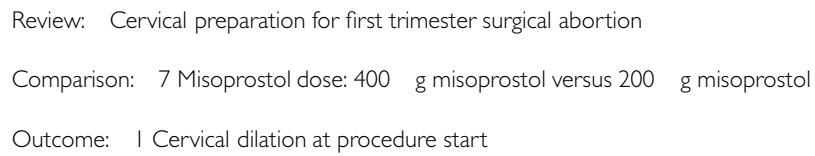

$40 \quad 7.2(1) \quad 43 \quad 6.6(0.9)$

Oppegaard 2004

$275 \quad 5.9(1.7)$

274

$5.4(1.7)$

315

317

Subtotal (95\% CI)

Heterogeneity: $\mathrm{Chi}^{2}=0.15, \mathrm{df}=1(\mathrm{P}=0.69) ; \mathrm{I}^{2}=0.0 \%$

Test for overall effect: $Z=4.46(P<0.0000 I)$

2 Vaginal misoprostol

$\begin{array}{lllll}\text { Ngai } 1999 & 37 & 6.8(1.3) & 40 & 6.8(1.2) \\ \text { Singh } 1998 & 30 & 8.2(0.8) & 30 & 6.4(1.3)\end{array}$

Subtotal $(\mathbf{9 5 \%} \mathrm{CI})$

67

70

Heterogeneity: $\mathrm{Ch}^{2}=20.33, \mathrm{df}=\mid(\mathrm{P}<0.0000 \mathrm{I}) ; \mathrm{I}^{2}=95 \%$

Test for overall effect: $Z=4.62(P<0.0000 I)$

3 Sublingual misoprostol

Vimala, Mittal 2004

60

$8.2(2)$

60

$6(1.2)$

60

60

Subtotal $(95 \% \mathrm{CI})$

Heterogeneity: not applicable

Test for overall effect: $Z=7.31(P<0.0000 I)$

Test for subgroup differences: $\mathrm{Chi}^{2}=27.03, \mathrm{df}=2(\mathrm{P}=0.00), \mathrm{I}^{2}=93 \%$ 
Analysis 7.2. Comparison 7 Misoprostol dose: $\mathbf{4 0 0} \mu \mathrm{g}$ misoprostol versus $\mathbf{2 0 0} \boldsymbol{\mu g}$ misoprostol, Outcome 2 Need for additional mechanical dilation.

Review: Cervical preparation for first trimester surgical abortion

Comparison: 7 Misoprostol dose: 400 g misoprostol versus 200 g misoprostol

Outcome: 2 Need for additional mechanical dilation

Study or subgroup Higher dose Lower dose Odds Ratio $\quad$ Weight

$\mathrm{n} / \mathrm{N} \quad \mathrm{n} / \mathrm{N}$

I Vaginal misoprostol

Singh 1998

$1 / 30$

$23 / 30$

$38.6 \%$

$0.01[0.00,0.09]$

Subtotal (95\% CI)

30

30

$38.6 \%$

$0.01[0.00,0.09]$

Total events: I (Higher dose), 23 (Lower dose)

Heterogeneity: not applicable

Test for overall effect: $Z=4.12(P=0.000037)$

2 Sublingual misoprostol

Vimala, Mittal 2004

$7 / 60$

$40 / 60$

$61.4 \%$

$0.07[0.03,0.17]$

Subtotal (95\% CI)

60

60

$61.4 \%$

$0.07[0.03,0.17]$

Total events: 7 (Higher dose), 40 (Lower dose)

Heterogeneity: not applicable

Test for overall effect: $Z=5.59$ ( $P<0.0000 \mathrm{I})$

Total (95\% CI)

90

Total events: 8 (Higher dose), 63 (Lower dose)

Heterogeneity: $\mathrm{Chi}^{2}=2.37, \mathrm{df}=\mathrm{I}(\mathrm{P}=0.12) ; \mathrm{I}^{2}=58 \%$

Test for overall effect: $Z=7.21(P<0.00001)$

Test for subgroup differences: $\mathrm{Chi}^{2}=0.0, \mathrm{df}=\mathrm{I}(\mathrm{P}=0.0), \mathrm{I}^{2}=0.0 \%$

90

$0.04[0.02,0.10]$ 
Analysis 7.3. Comparison 7 Misoprostol dose: $400 \mu \mathrm{g}$ misoprostol versus $\mathbf{2 0 0} \boldsymbol{\mu g}$ misoprostol, Outcome 3 Pain with cervical priming.

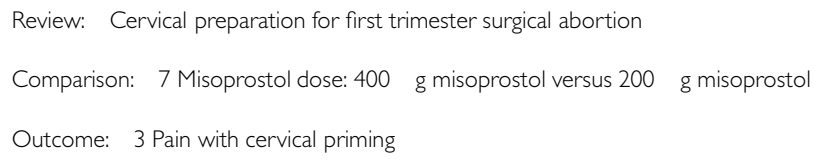

| Vaginal misoprostol

$$
\text { Singh } 1998
$$

$2 / 30$

Total events: II (Higher dose), 2 (Lower dose)

Heterogeneity: not applicable

Test for overall effect: $Z=2.54(P=0.01 \mathrm{I})$

2 Sublingual misoprostol

Vimala, Mittal 2004

Subtotal (95\% CI)

Heterogeneity: not applicable

Test for overall effect: $Z=1.64(P=0.10)$

Total (95\% CI)

90

90

$89.4 \%$

$1.84[0.89,3.80]$

Total events: 48 (Higher dose), 30 (Lower dose)

Heterogeneity: $\mathrm{Chi}^{2}=2.72, \mathrm{df}=\mathrm{I}(\mathrm{P}=0.10) ; \mathrm{I}^{2}=63 \%$

Test for overall effect: $Z=2.79(P=0.0052)$

Test for subgroup differences: $C h i^{2}=0.0, d f=I(P=0.0), L^{2}=0.0 \%$

$10.6 \% \quad 8.11[1.61,40.77]$

$10.6 \% \quad 8.11[1.61,40.77]$

$2.50[1.31,4.75]$ 
Analysis 7.4. Comparison 7 Misoprostol dose: $400 \mu \mathrm{g}$ misoprostol versus $200 \mu \mathrm{g}$ misoprostol, Outcome 4 Procedure length (minutes).

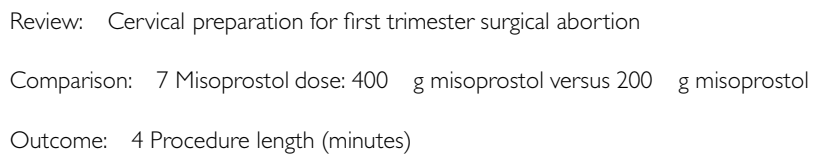

Subtotal (95\% CI)

Heterogeneity: not applicable

Test for overall effect: $Z=0.57(P=0.57)$

2 Sublingual misoprostol

Vimala, Mittal 2004

Heterogeneity: not applicable

Test for overall effect: $Z=5.10(P<0.00001)$

$$
\text { Total (95\% CI) } 97
$$

Heterogeneity: $\mathrm{Ch}^{2}=3.93, \mathrm{df}=\mathrm{I}(\mathrm{P}=0.05) ; \mathrm{I}^{2}=75 \%$

Test for overall effect: $Z=4.73(P<0.0000 I)$

Test for subgroup differences: $\mathrm{Chi}^{2}=3.93, \mathrm{df}=\mathrm{I}(\mathrm{P}=0.05), \mathrm{I}^{2}=75 \%$

23.6\% $\quad-0.30[-1.34,0.74]$

$23.6 \%-0.30[-1.34,0.74]$ 
Analysis 8.I. Comparison 8 Interval between misoprostol application and procedure: 2 hours versus 3 hours, Outcome I Cervical dilation at procedure start.

Review: Cervical preparation for first trimester surgical abortion

Comparison: 8 Interval between misoprostol application and procedure: 2 hours versus 3 hours

Outcome: I Cervical dilation at procedure start

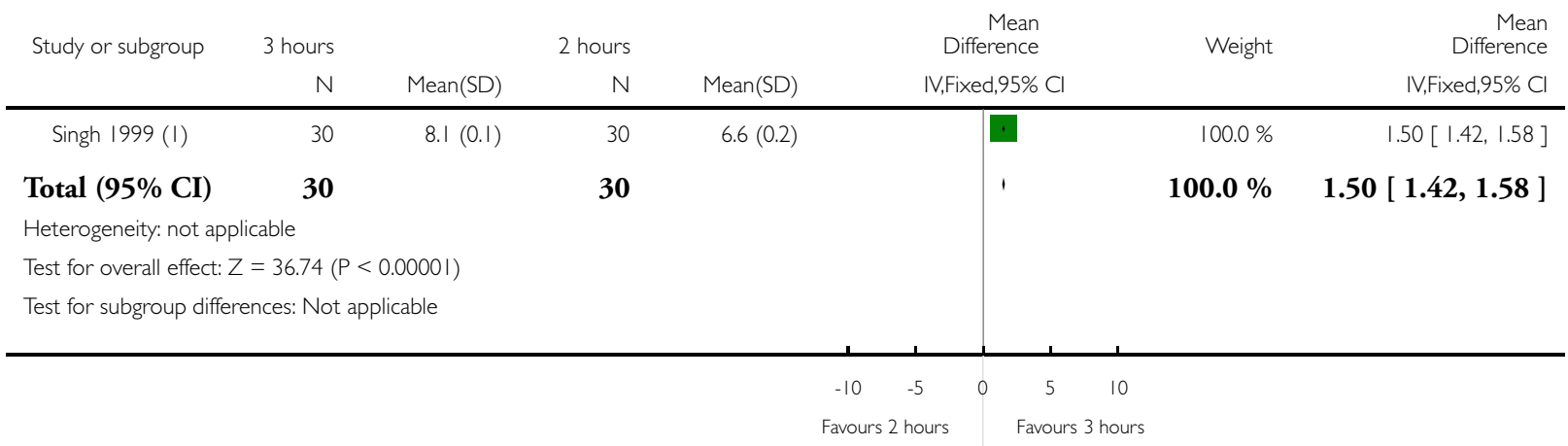

(I) 400 g vaginal misoprostol 3 hours prior, and 600 g vaginal misoprostol 2 hours prior

Analysis 8.2. Comparison 8 Interval between misoprostol application and procedure: $\mathbf{2}$ hours versus 3 hours, Outcome 2 Need for additional mechanical dilation.

Review: Cervical preparation for first trimester surgical abortion

Comparison: 8 Interval between misoprostol application and procedure: 2 hours versus 3 hours

Outcome: 2 Need for additional mechanical dilation

\begin{tabular}{|c|c|c|c|c|c|c|c|c|}
\hline \multirow{3}{*}{$\begin{array}{l}\text { Study or subgroup } \\
\text { Singh } 1999(1)\end{array}$} & \multirow{3}{*}{$\begin{array}{r}\begin{array}{r}3 \text { hours } \\
n / N\end{array} \\
2 / 30\end{array}$} & \multirow{3}{*}{$\begin{array}{r}2 \text { hours } \\
\text { n/N }\end{array}$} & \multirow{2}{*}{\multicolumn{4}{|c|}{$\begin{array}{r}\text { Odds Ratio } \\
\mathrm{M}-\mathrm{H}, \text { Fixed,95\% Cl}\end{array}$}} & \multirow[t]{2}{*}{ Weight } & \multirow{2}{*}{$\begin{array}{r}\text { Odds Ratio } \\
\text { M-H,Fixed,95\% Cl }\end{array}$} \\
\hline & & & & & & & & \\
\hline & & & - & & & & $100.0 \%$ & $0.01[0.00,0.08]$ \\
\hline Total $(95 \%$ CI $)$ & 30 & 30 & & & & & $100.0 \%$ & $0.01[0.00,0.08]$ \\
\hline \multicolumn{9}{|c|}{ Total events: 2 (3 hours), 25 (2 hours) } \\
\hline \multicolumn{9}{|c|}{ Heterogeneity: not applicable } \\
\hline \multicolumn{9}{|c|}{ Test for overall effect: $Z=4.82(P<0.0000 I)$} \\
\hline \multicolumn{9}{|c|}{ Test for subgroup differences: Not applicable } \\
\hline & & & 0.01 & 0.1 & 10 & 100 & & \\
\hline \multicolumn{9}{|c|}{ Favours 3 hours } \\
\hline
\end{tabular}

Cervical preparation for first trimester surgical abortion (Review)

Copyright $\odot 2010$ The Cochrane Collaboration. Published by John Wiley \& Sons, Ltd. 
Analysis 8.3. Comparison 8 Interval between misoprostol application and procedure: $\mathbf{2}$ hours versus 3 hours, Outcome 3 Pain with cervical priming.

Review: Cervical preparation for first trimester surgical abortion

Comparison: 8 Interval between misoprostol application and procedure: 2 hours versus 3 hours

Outcome: 3 Pain with cervical priming

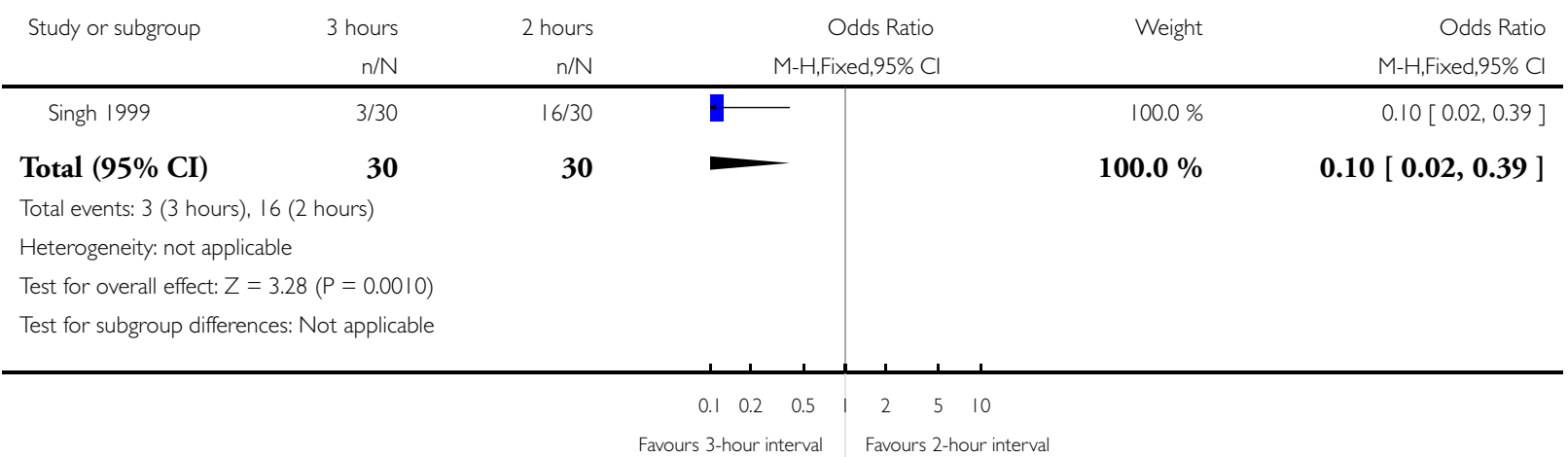




\section{Analysis 9.1. Comparison 9 Route of misoprostol administration, Outcome I Cervical dilation at procedure}

start.

Review: Cervical preparation for first trimester surgical abortion

Comparison: 9 Route of misoprostol administration

Outcome: I Cervical dilation at procedure start

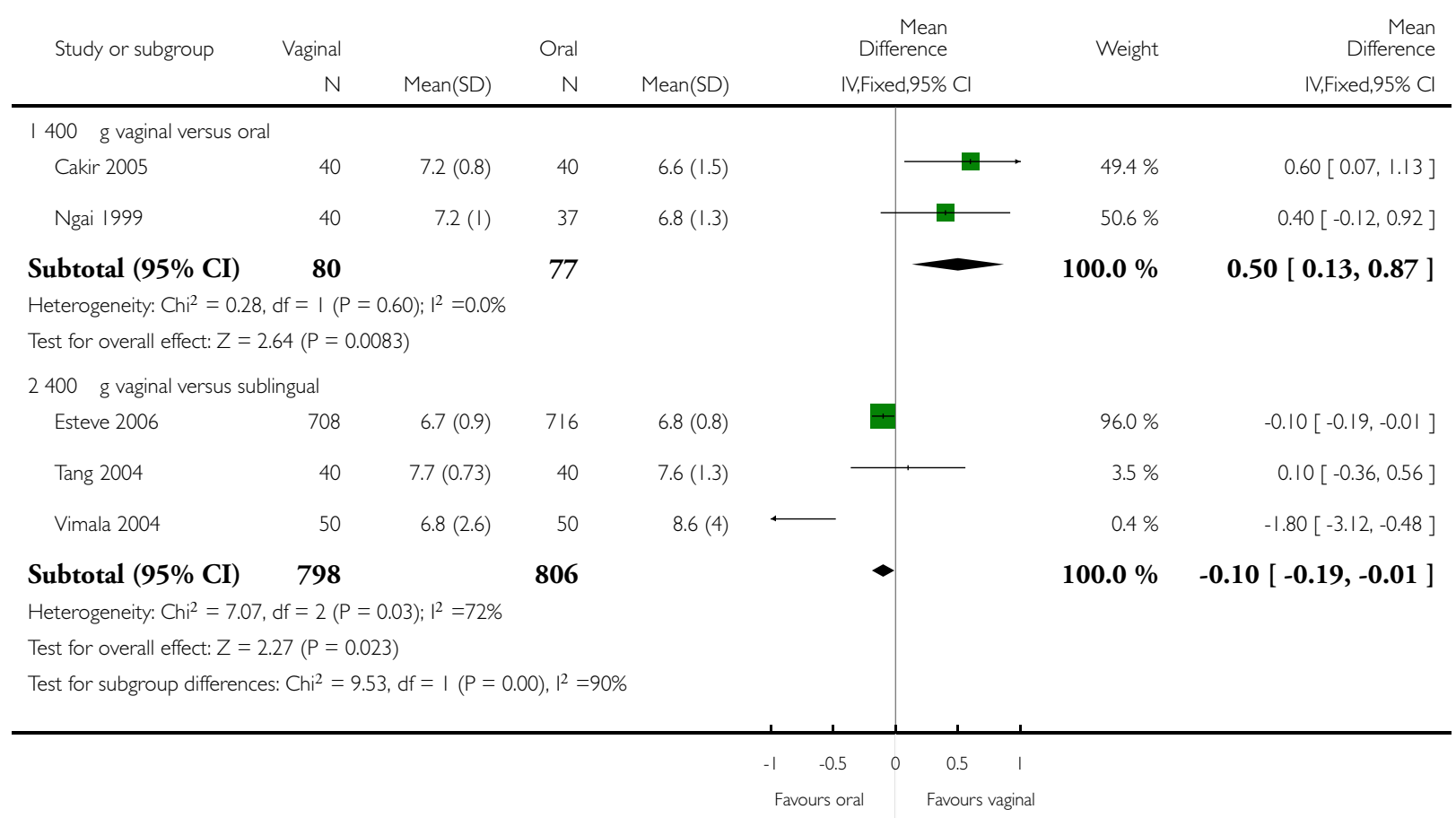


Analysis 9.2. Comparison 9 Route of misoprostol administration, Outcome 2 Need for additional mechanical dilation.

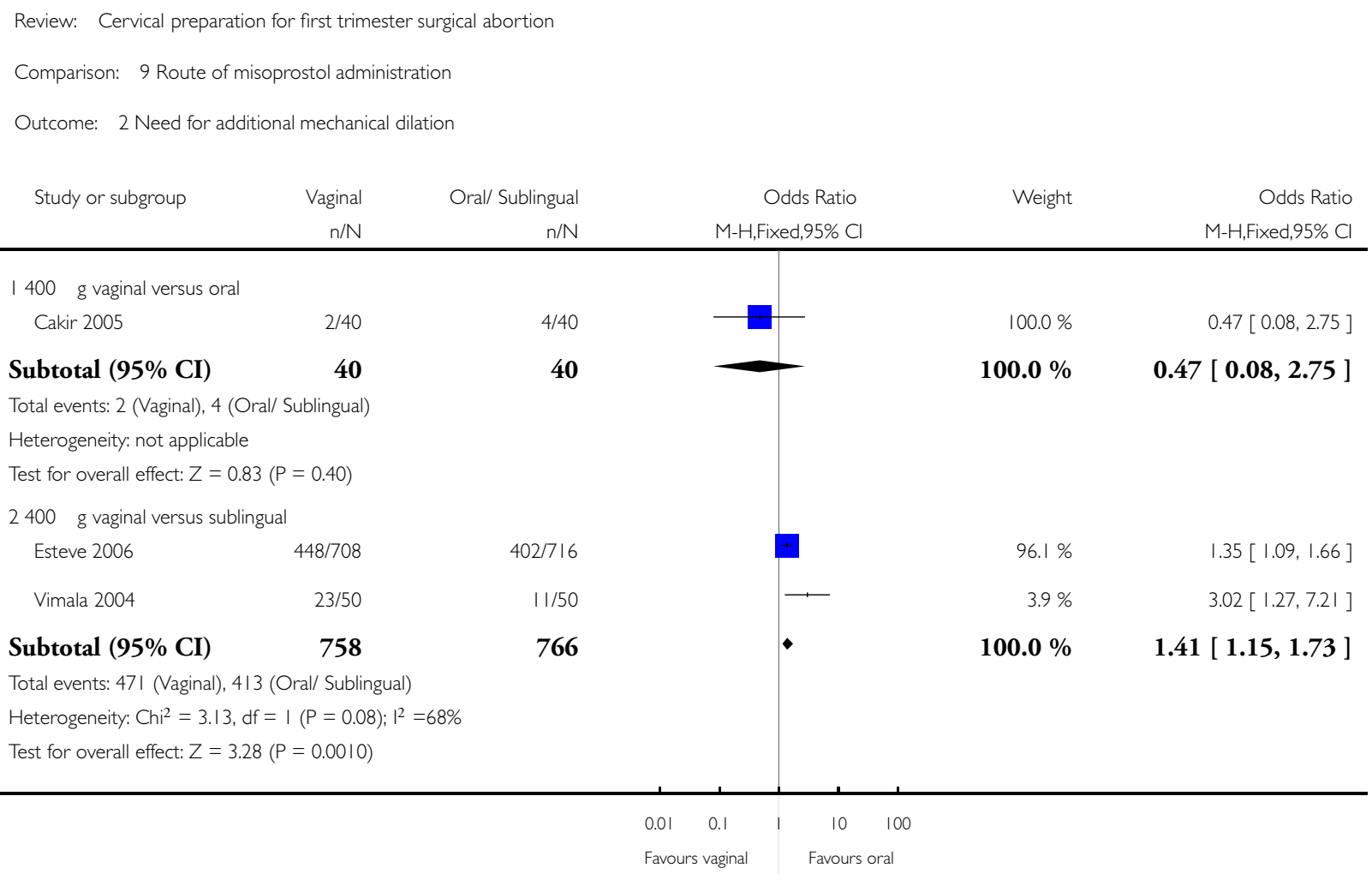


Analysis 9.3. Comparison 9 Route of misoprostol administration, Outcome 3 Side-effects: occurrence of nausea.

Review: Cervical preparation for first trimester surgical abortion

Comparison: 9 Route of misoprostol administration

Outcome: 3 Side-effects: occurrence of nausea

$\begin{array}{lllll}\text { Study or subgroup } & \text { Vaginal } & \text { Oral } & \text { Odds Ratio } & \text { Weight }\end{array}$

$\mathrm{n} / \mathrm{N} \quad \mathrm{M} / \mathrm{H}, \mathrm{Fixed}, 95 \% \mathrm{Cl} \quad \mathrm{M}-\mathrm{H}, \mathrm{Fixed}, 95 \% \mathrm{Cl}$

I 400 g vaginal versus oral

$\begin{array}{lll}\text { Cakir } 2005 & 19 / 40 \quad 23 / 40\end{array}$

Ngai 1999

0/37

$2 / 40$

77

80

Subtotal $(\mathbf{9 5 \%}$ CI)

77

Total events: 19 (Vaginal), 25 (Oral)

Heterogeneity: $\mathrm{Ch}^{2}=0.53, \mathrm{df}=\mathrm{I}(\mathrm{P}=0.47) ; \mathrm{I}^{2}=0.0 \%$

Test for overall effect: $Z=1.23(P=0.22)$

$2400 \mathrm{~g}$ vaginal versus sublingual

Esteve 2006

18/708 $\quad 89 / 716$

Hamoda 2004

$11 / 37$

22/37

Tang 2004

$14 / 40$

Vimala 2004 (I)

9/50

$8 / 40$

$13 / 50$

Subtotal $(\mathbf{9 5 \%}$ CI)

835

843

$+$

\section{$83.6 \%$}

$0.67[0.28,1.62]$

Total events: 52 (Vaginal), 132 (Oral)

Heterogeneity: $\mathrm{Ch}^{2}=19.94, \mathrm{df}=3(\mathrm{P}=0.000 \mathrm{I7}) ; \mathrm{I}^{2}=85 \%$

Test for overall effect: $Z=6.16(P<0.0000 \mathrm{I})$

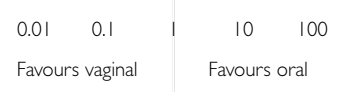

( I) measurement included nausea and vomiting 
Analysis 9.4. Comparison 9 Route of misoprostol administration, Outcome 4 Cervical dilation at procedure start.

Review: Cervical preparation for first trimester surgical abortion

Comparison: 9 Route of misoprostol administration

Outcome: 4 Cervical dilation at procedure start

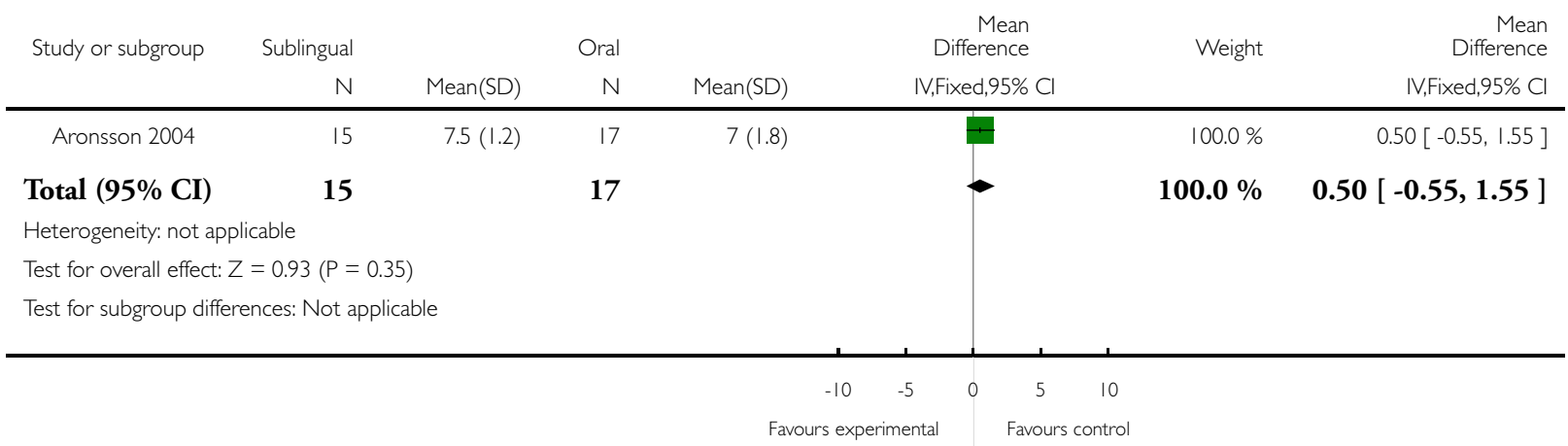




\section{Analysis 9.5. Comparison 9 Route of misoprostol administration, Outcome 5 Procedure length (minutes).}

Review: Cervical preparation for first trimester surgical abortion

Comparison: 9 Route of misoprostol administration

Outcome: 5 Procedure length (minutes)

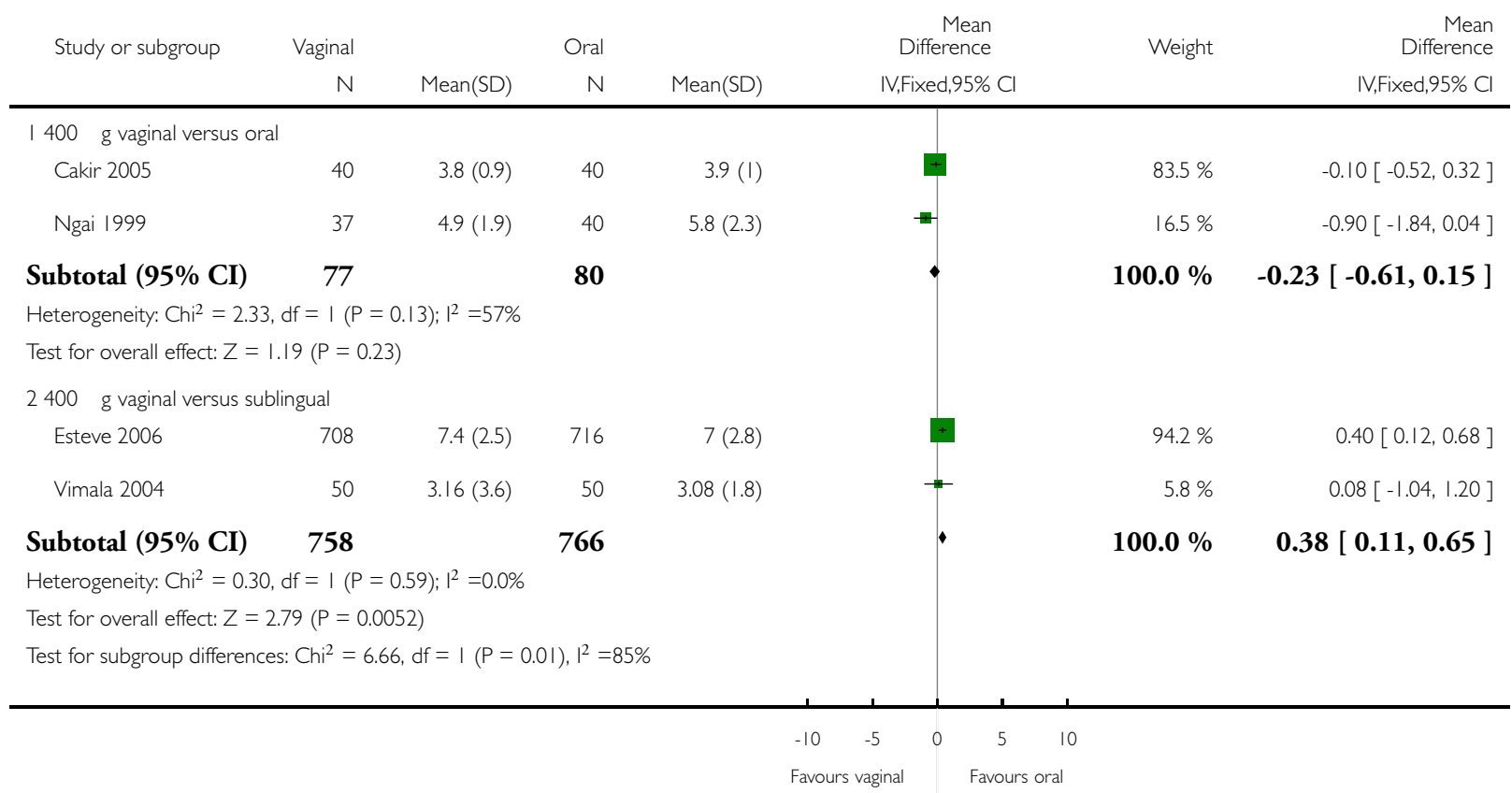


Analysis 9.6. Comparison 9 Route of misoprostol administration, Outcome 6 Patient disatisfaction.

Review: Cervical preparation for first trimester surgical abortion

Comparison: 9 Route of misoprostol administration

Outcome: 6 Patient disatisfaction

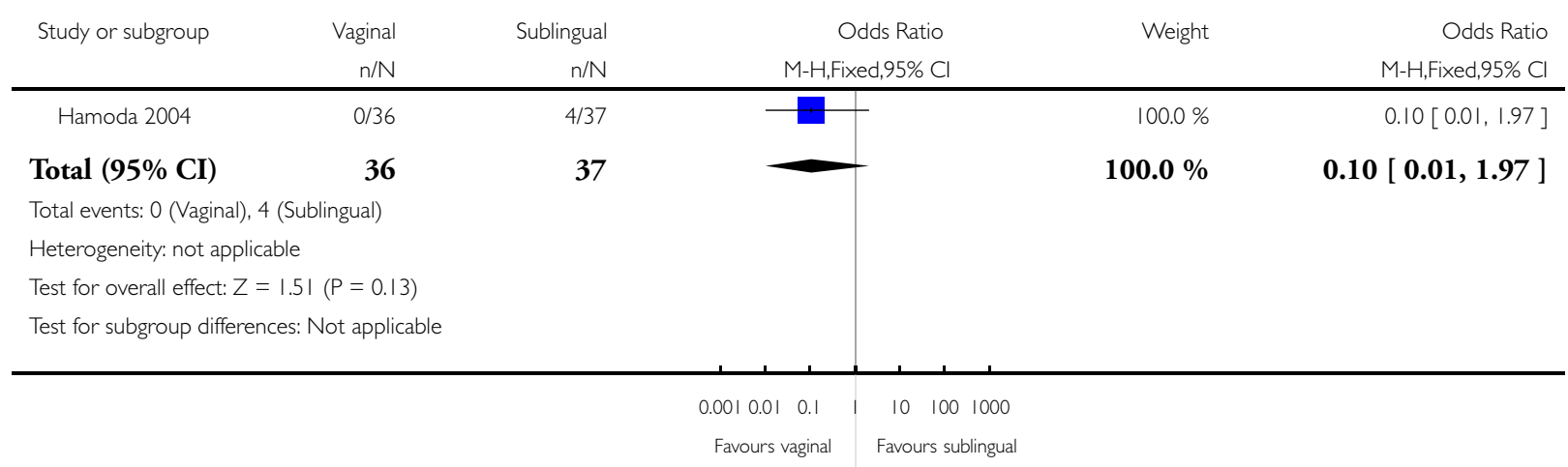




\section{Analysis 10.I. Comparison 10 Misoprostol versus gemeprost, Outcome I Cervical dilation at procedure}

start.

Review: Cervical preparation for first trimester surgical abortion

Comparison: 10 Misoprostol versus gemeprost

Outcome: I Cervical dilation at procedure start

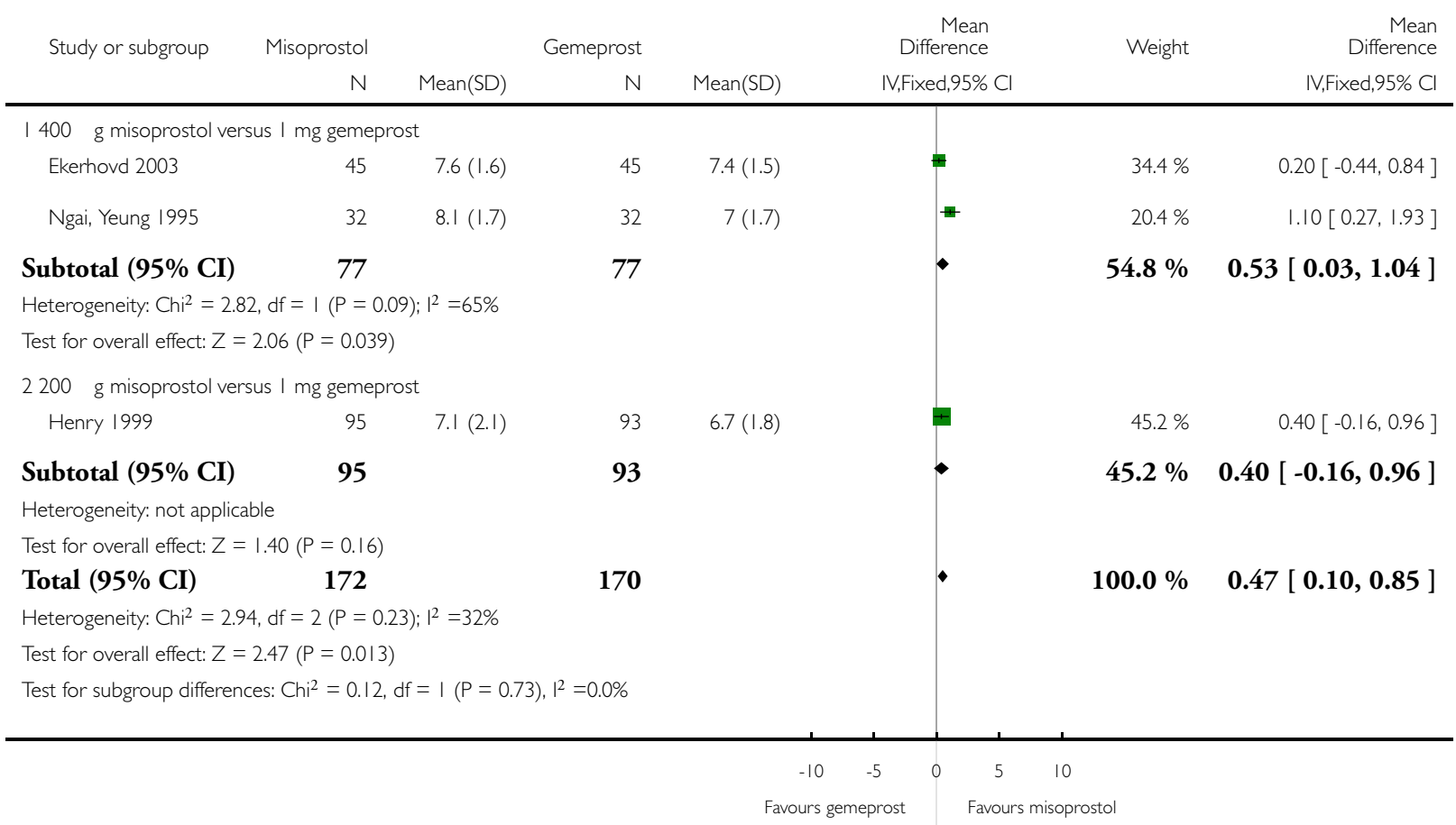


Analysis 10.2. Comparison 10 Misoprostol versus gemeprost, Outcome 2 Side-effects of $200 \mu \mathrm{g}$ misoprostol versus gemeprost.

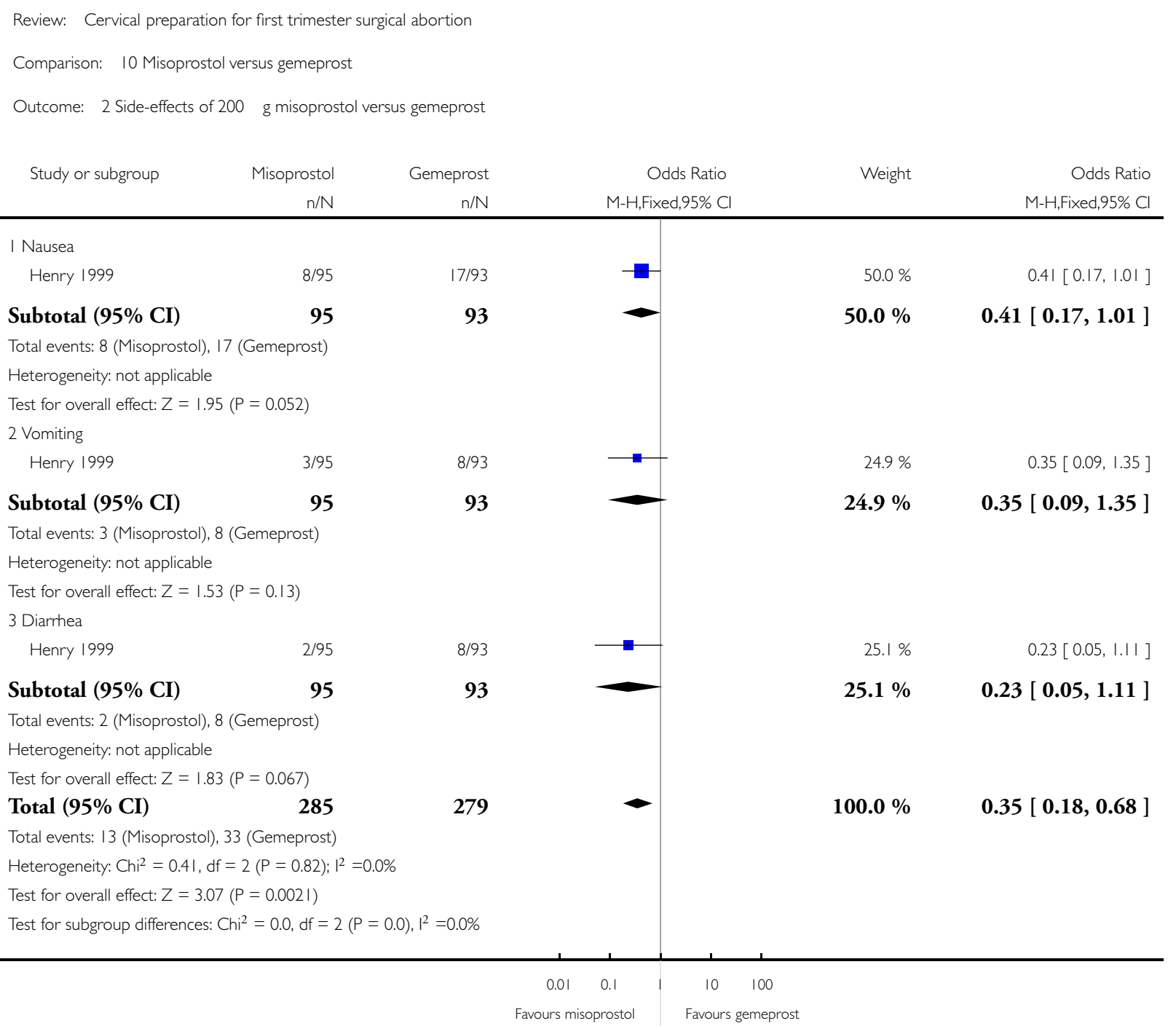


Analysis 10.3. Comparison 10 Misoprostol versus gemeprost, Outcome 3 Side-effects of 400 misoprostol versus gemeprost.

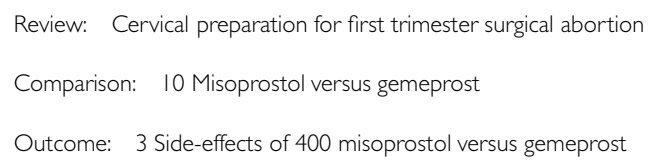

Odds Ratio

$n / N \quad n / N$

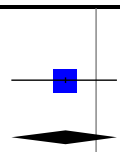

I Nausea

Ngai, Yeung 1995

2/32

$5 / 32$

Subtotal $(95 \% \mathrm{CI})$

32

32

Total events: 2 (Misoprostol), 5 (Gemeprost)

Heterogeneity: not applicable

Test for overall effect: $Z=1.16(P=0.24)$

2 Vomiting

Ngai, Yeung 1995

1/32

$1 / 32$

Subtotal (95\% CI)

32

Total events: I (Misoprostol), I (Gemeprost)

Heterogeneity: not applicable

Test for overall effect: $Z=0.0(P=1.0)$

Total $(95 \%$ CI $)$

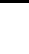

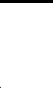

Total events: 3 (Misoprostol), 6 (Gemeprost)

Heterogeneity: $\mathrm{Chi}^{2}=0.37, \mathrm{df}=\mathrm{I}(\mathrm{P}=0.54) ; \mathrm{I}^{2}=0.0 \%$

Test for overall effect: $Z=1.03(P=0.30)$

Test for subgroup differences: $\mathrm{Chi}^{2}=0.0, \mathrm{df}=\mathrm{I}(\mathrm{P}=0.0), \mathrm{I}^{2}=0.0 \%$

\section{4}

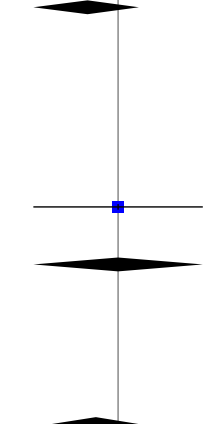

$82.9 \% \quad 0.36[0.06,2.01]$

$82.9 \% \quad 0.36[0.06,2.01]$

$1.00[0.06,16.71]$

$17.1 \% \quad 1.00[0.06,16.71]$

1.

Favours misoprostol Favours gemeprost 
Analysis 10.4. Comparison 10 Misoprostol versus gemeprost, Outcome 4 Procedure length (minutes).

Review: Cervical preparation for first trimester surgical abortion

Comparison: 10 Misoprostol versus gemeprost

Outcome: 4 Procedure length (minutes)

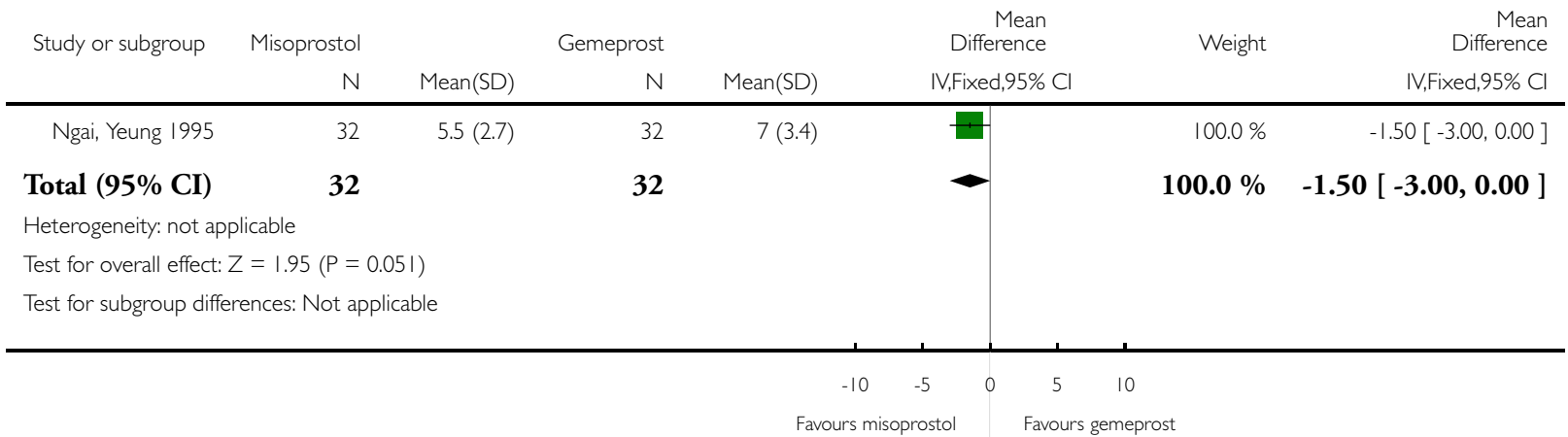




\section{Analysis II.I. Comparison I I Misoprostol versus mifepristone, Outcome I Cervical dilation at procedure start.}

Review: Cervical preparation for first trimester surgical abortion

Comparison: II Misoprostol versus mifepristone

Outcome: I Cervical dilation at procedure start

\begin{tabular}{|c|c|c|c|c|c|c|c|c|c|}
\hline \multirow[t]{2}{*}{ Study or subgroup } & \multirow{2}{*}{$\begin{array}{r}\text { Misoprostol } \\
\mathrm{N}\end{array}$} & \multicolumn{3}{|c|}{ Mifepristone } & \multirow{2}{*}{\multicolumn{3}{|c|}{$\begin{array}{c}\text { Mean } \\
\text { Difference } \\
\text { IV,Fixed,95\% Cl }\end{array}$}} & \multirow[t]{2}{*}{ Weight } & \multirow{2}{*}{$\begin{array}{r}\text { Mean } \\
\text { Difference } \\
\text { IV,Fixed,95\% Cl }\end{array}$} \\
\hline & & Mean(SD) & N & Mean(SD) & & & & & \\
\hline \multicolumn{10}{|c|}{ I 800 g misoprostol versus 200 mg mifepristone } \\
\hline Ashok 2000 (I) & 30 & $7.6(1.4)$ & 30 & $8.3(0.9)$ & & + & & $68.8 \%$ & $-0.70[-1.30,-0.10]$ \\
\hline Subtotal $(95 \% \mathrm{CI})$ & 30 & & 30 & & & $\bullet$ & & $68.8 \%$ & $-0.70[-1.30,-0.10]$ \\
\hline \multicolumn{10}{|c|}{ Heterogeneity: not applicable } \\
\hline \multicolumn{10}{|c|}{ Test for overall effect: $Z=2.30(P=0.021)$} \\
\hline \multicolumn{10}{|c|}{2600 g misoprostol versus 400 mg mifepristone (divided doses) } \\
\hline Bokstrom 1998 (2) & 15 & $5.9(1.5)$ & 15 & $6.9(0.9)$ & & $\#$ & & $31.2 \%$ & $-1.00[-1.89,-0.11]$ \\
\hline Subtotal $(95 \% \mathrm{CI})$ & 15 & & 15 & & & $<$ & & $31.2 \%$ & $-1.00[-1.89,-0.11]$ \\
\hline \multicolumn{10}{|c|}{ Heterogeneity: not applicable } \\
\hline \multicolumn{10}{|c|}{ Test for overall effect: $Z=2.21(P=0.027)$} \\
\hline Total (95\% CI) & 45 & & 45 & & & $\bullet$ & & $100.0 \%$ & $-0.79[-1.29,-0.30]$ \\
\hline \multicolumn{10}{|c|}{ Heterogeneity: $\mathrm{Chi}^{2}=0.30, \mathrm{df}=\mathrm{I}(\mathrm{P}=0.58) ; \mathrm{I}^{2}=0.0 \%$} \\
\hline \multicolumn{10}{|c|}{ Test for overall effect: $Z=3.15(P=0.0016)$} \\
\hline \multicolumn{10}{|c|}{ Test for subgroup differences: $\mathrm{Chi}^{2}=0.30, \mathrm{df}=\mid(P=0.58), \mathrm{I}^{2}=0.0 \%$} \\
\hline & & & & -10 & -5 & 0 & 5 & 10 & \\
\hline \multicolumn{10}{|c|}{ Favours mifepristone } \\
\hline (I) Vaginally-applied misc & rostol & & & & & & & & \\
\hline
\end{tabular}


Analysis II.2. Comparison II Misoprostol versus mifepristone, Outcome 2 Side-effects: nausea and vomiting.

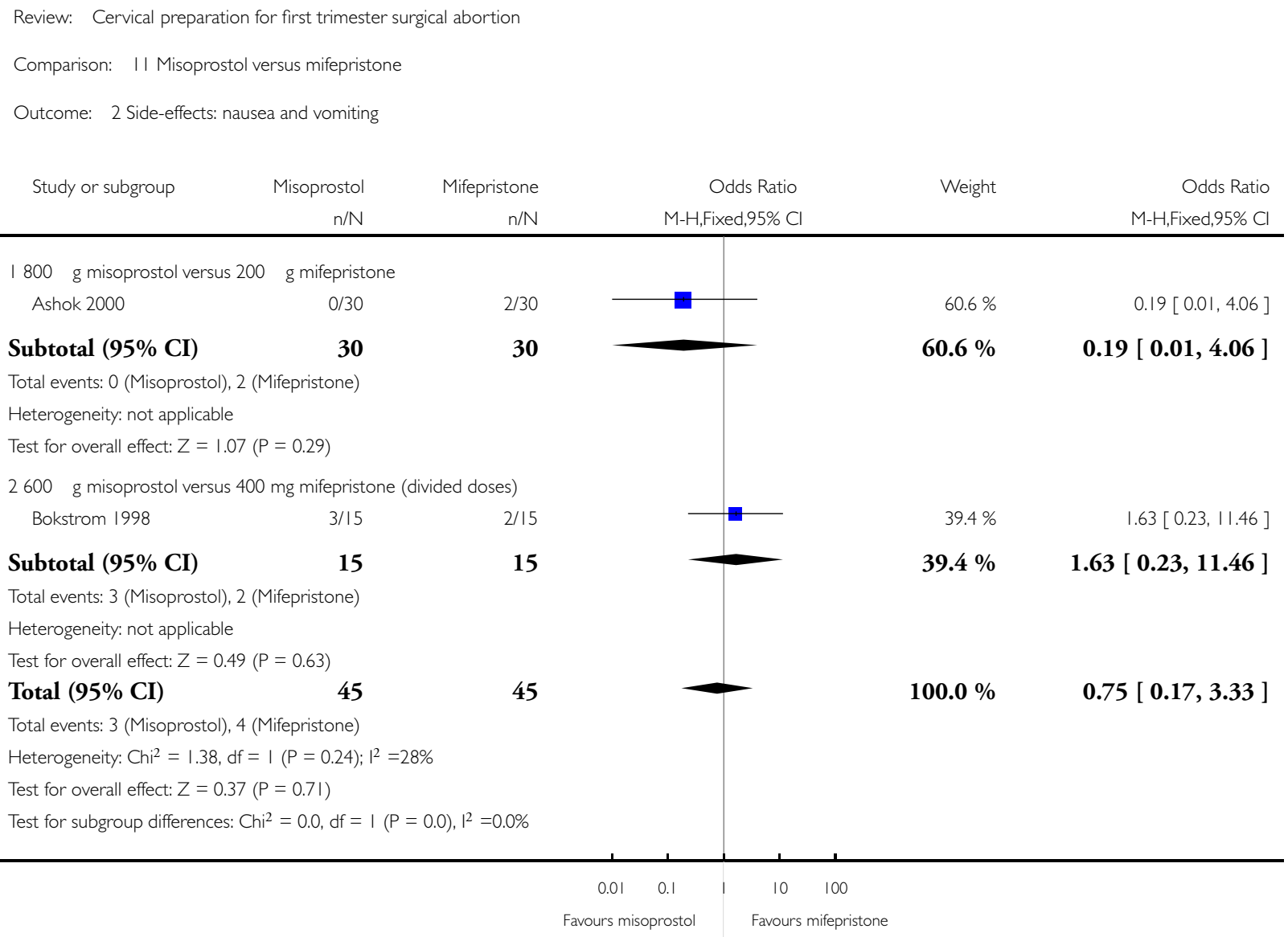


Analysis 12.I. Comparison I 2 Misoprostol versus laminaria, Outcome I Need for additional mechanical dilation.

Review: Cervical preparation for first trimester surgical abortion

Comparison: 12 Misoprostol versus laminaria

Outcome: I Need for additional mechanical dilation

Study or subgroup Misoprostol Laminaria $\quad$ Odds Ratio Odds Ratio

$n / N \quad n / N$

M-H,Fixed,95\% C M-H,Fixed,95\% Cl

I 200 g misoprostol
Burnett 2005

$26 / 37$

$22 / 33$

Subtotal (95\% CI)

37

33

5

Total events: 26 (Misoprostol), 22 (Laminaria)

Heterogeneity: not applicable

Test for overall effect: $Z=0.32(P=0.75)$

2400 g misoprostol

Maclsaac 1999

Subtotal (95\% CI)

Total events: 22 (Misoprostol), 7 (Laminaria)

Heterogeneity: not applicable

Test for overall effect: $Z=0.21(P=0.83)$

Total (95\% CI)

Total events: 48 (Misoprostol), 29 (Laminaria)

Heterogeneity: Chi $^{2}=0.14, d f=I(P=0.7 I) ;\left.\right|^{2}=0.0 \%$

Test for overall effect: $Z=0.11(P=0.91)$

Test for subgroup differences: $\mathrm{Chi}^{2}=0.0, \mathrm{df}=\mathrm{I}(\mathrm{P}=0.0), \mathrm{I}^{2}=0.0 \%$ 


\section{Analysis 12.2. Comparison 12 Misoprostol versus laminaria, Outcome 2 Procedure length (minutes).}

Review: Cervical preparation for first trimester surgical abortion

Comparison: 12 Misoprostol versus laminaria

Outcome: 2 Procedure length (minutes)

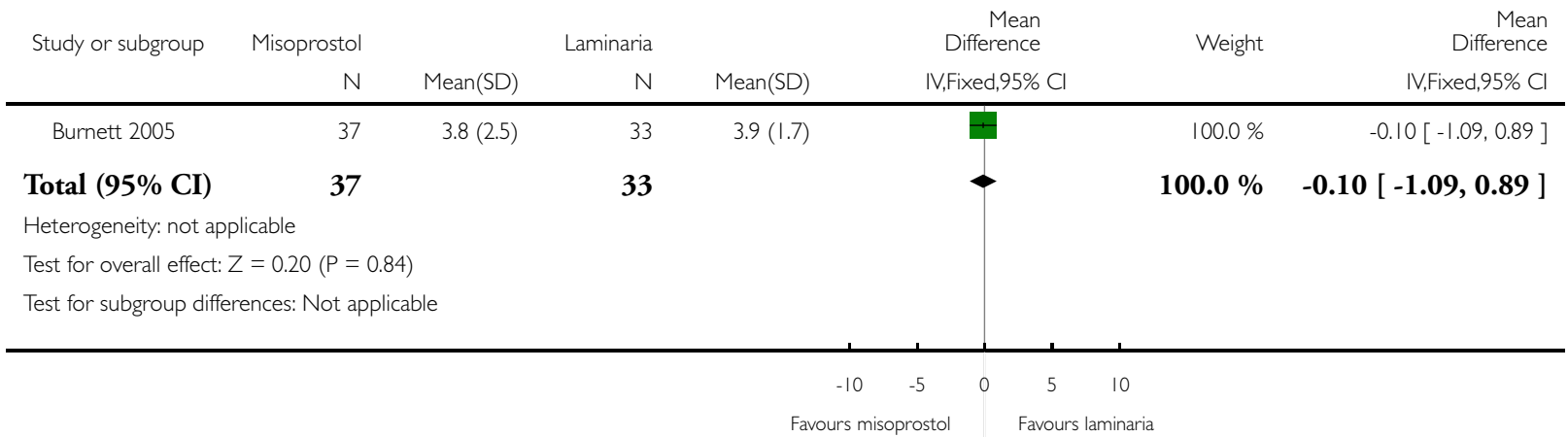

Analysis 12.3. Comparison I 2 Misoprostol versus laminaria, Outcome 3 Patient disatisfaction.

Review: Cervical preparation for first trimester surgical abortion

Comparison: 12 Misoprostol versus laminaria

Outcome: 3 Patient disatisfaction

\begin{tabular}{|c|c|c|c|c|c|}
\hline \multirow{2}{*}{ Study or subgroup } & Misoprostol & Laminaria & Odds Ratio & \multirow[t]{2}{*}{ Weight } & \multirow{2}{*}{$\begin{array}{r}\text { Odds Ratio } \\
\text { M-H,Fixed,95\% C }\end{array}$} \\
\hline & $\mathrm{n} / \mathrm{N}$ & $\mathrm{n} / \mathrm{N}$ & M-H,Fixed,95\% Cl & & \\
\hline Burnett 2005 (I) & $1 \mid / 37$ & $19 / 33$ & & $100.0 \%$ & $0.31[0.12,0.84]$ \\
\hline
\end{tabular}

Total (95\% CI)

37

33

$100.0 \%$

$0.31[0.12,0.84$ ]

Total events: II (Misoprostol), 19 (Laminaria)

Heterogeneity: not applicable

Test for overall effect: $Z=2.32(P=0.021)$

Test for subgroup differences: Not applicable

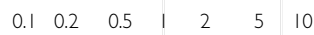

Favours misoprostol Favours laminaria

(I) Satisfaction measured by the woman's answer to question: would you have the same dilating device again? 


\section{Analysis 13.I. Comparison I3 Misoprostol versus prostaglandin F2 $\alpha$, Outcome I Need for additional}

mechanical dilation.

Review: Cervical preparation for first trimester surgical abortion

Comparison: 13 Misoprostol versus prostaglandin $\mathrm{F}_{2 \mathrm{a}}$

Outcome: I Need for additional mechanical dilation

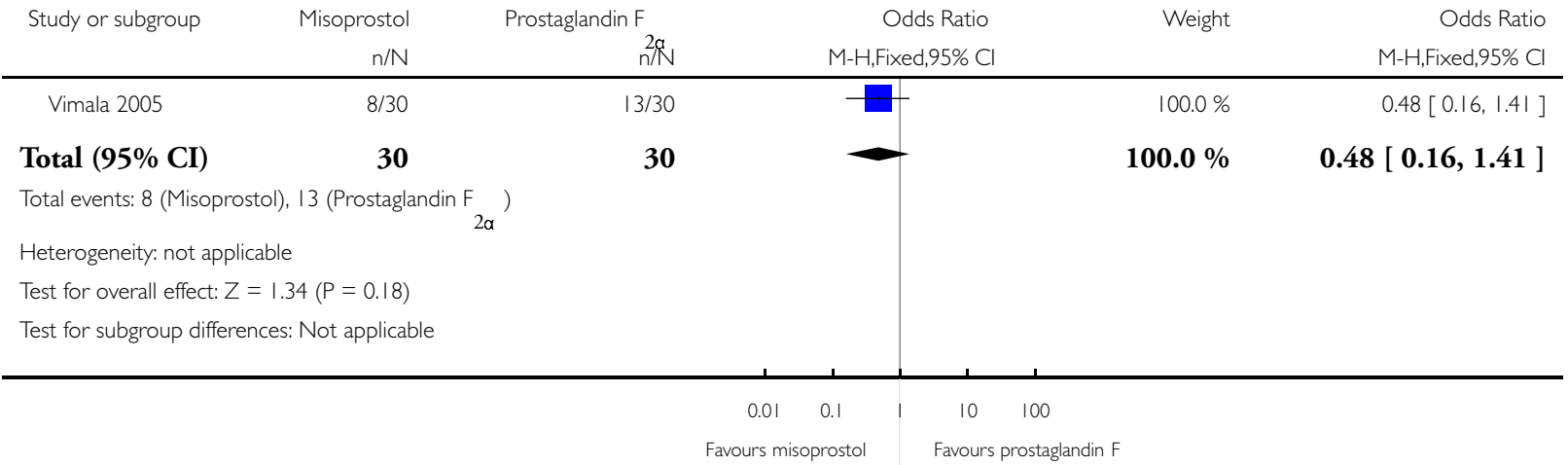

Analysis 13.2. Comparison I 3 Misoprostol versus prostaglandin F2 $\alpha$, Outcome 2 Cervical dilation at procedure start.

Review: Cervical preparation for first trimester surgical abortion

Comparison: 13 Misoprostol versus prostaglandin ${ }_{2 a}$

Outcome: 2 Cervical dilation at procedure start

\begin{tabular}{|c|c|c|c|c|c|c|c|c|}
\hline \multirow[t]{2}{*}{ Study or subgroup } & Misoprostol & \multicolumn{2}{|r|}{ Prostaglandin F } & \multicolumn{3}{|c|}{$\begin{array}{r}\text { Mean } \\
\text { Difference }\end{array}$} & \multicolumn{2}{|r|}{$\begin{array}{r}\text { Mean } \\
\text { Difference }\end{array}$} \\
\hline & N & Mean(SD) & $2 q$ & Mean(SD) & & $\mathrm{ked}, 95 \% \mathrm{Cl}$ & & IV,Fixed,95\% Cl \\
\hline Vimala 2005 & 30 & $8.8(1.6)$ & 30 & $7(1.4)$ & & + & $100.0 \%$ & $1.80[1.04,2.56]$ \\
\hline Total (95\% CI) & 30 & & 30 & & & $\bullet$ & $100.0 \%$ & $1.80[1.04,2.56]$ \\
\hline \multicolumn{9}{|c|}{ Heterogeneity: not applicable } \\
\hline \multicolumn{9}{|c|}{ Test for overall effect: $Z=4.64(P<0.0000$ I) } \\
\hline \multicolumn{9}{|c|}{ Test for subgroup differences: Not applicable } \\
\hline & & & & -10 & -5 & 5 & 10 & \\
\hline
\end{tabular}


Analysis 13.3. Comparison I 3 Misoprostol versus prostaglandin F2 $\alpha$, Outcome 3 Side-effects: nausea and vomiting.

Review: Cervical preparation for first trimester surgical abortion

Comparison: 13 Misoprostol versus prostaglandin $F$

Outcome: 3 Side-effects: nausea and vomiting

\begin{tabular}{|c|c|c|c|c|c|}
\hline Study or subgroup & $\begin{array}{r}\text { Misoprostol } \\
\mathrm{n} / \mathrm{N}\end{array}$ & Prostaglandin $\mathrm{F}_{n}^{2 / R}$ & $\begin{array}{c}\text { Odds Ratio } \\
\text { M-H,Fixed,95\% Cl }\end{array}$ & Weight & $\begin{array}{r}\text { Odds Ratio } \\
\text { M-H,Fixed, } 95 \% \mathrm{Cl}\end{array}$ \\
\hline Vimala 2005 & $1 / 30$ & $6 / 30$ & 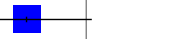 & $100.0 \%$ & $0.14[0.02,1.23]$ \\
\hline Total $(95 \%$ CI) & 30 & 30 & 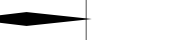 & $100.0 \%$ & $0.14[0.02,1.23]$ \\
\hline
\end{tabular}

Total events: I (Misoprostol), 6 (Prostaglandin F ${ }_{2 \alpha}$ )

Heterogeneity: not applicable

Test for overall effect: $Z=1.78(P=0.076)$

Test for subgroup differences: Not applicable

$\begin{array}{ccccc}0.01 & 0.1 & 1 & 10 & 100 \\ \text { Favours misoprostol } & & \text { Favours prostaglandin } \mathrm{F}\end{array}$

\section{Analysis 13.4. Comparison I 3 Misoprostol versus prostaglandin F2 $\alpha$, Outcome 4 Procedure length} (minutes).

Review: Cervical preparation for first trimester surgical abortion

Comparison: 13 Misoprostol versus prostaglandin ${ }_{2 \alpha}$

Outcome: 4 Procedure length (minutes)

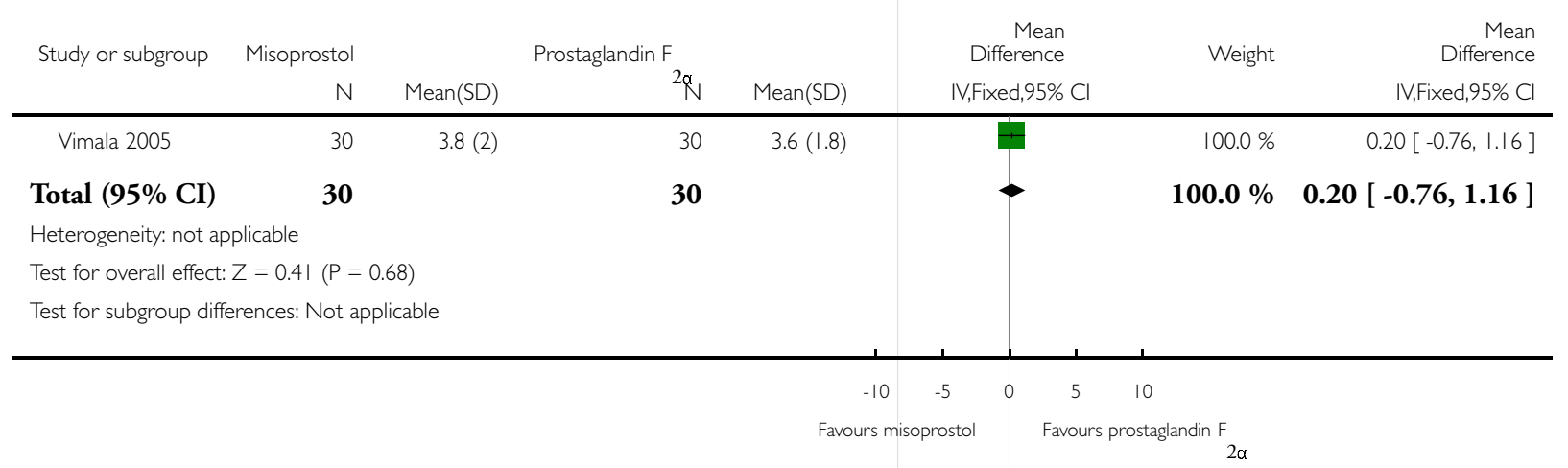


Analysis 13.5. Comparison I 3 Misoprostol versus prostaglandin F2 $\alpha$, Outcome 5 Patient disatisfaction.

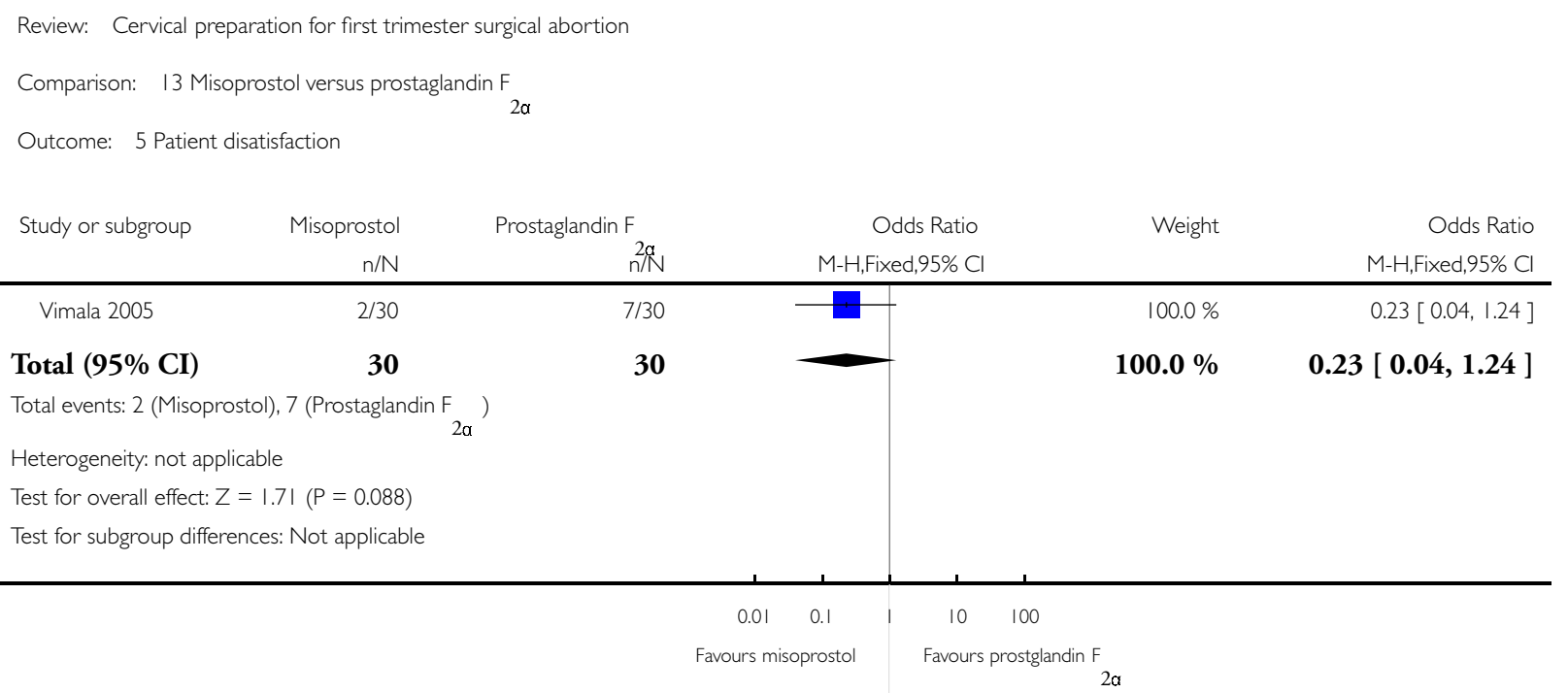

\section{Analysis I4.I. Comparison I 4 Gemeprost I mg versus Lamicel, Outcome I Need for additional mechanical dilation.}

Review: Cervical preparation for first trimester surgical abortion

Comparison: 14 Gemeprost I mg versus Lamicel

Outcome: I Need for additional mechanical dilation

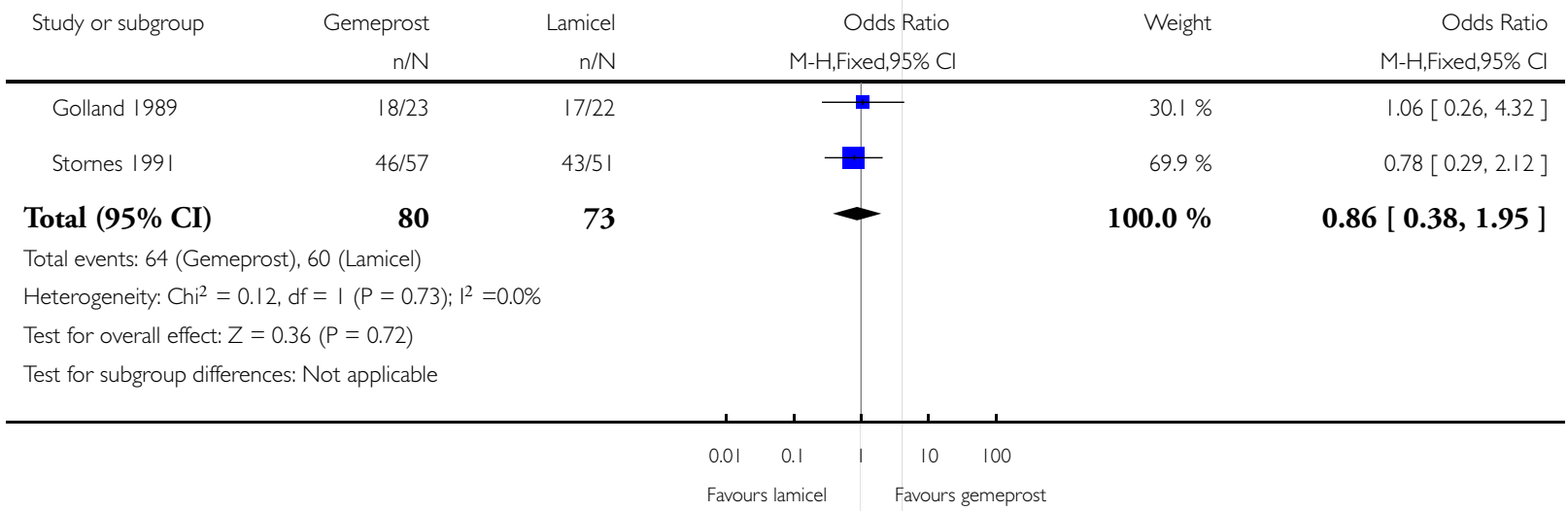




\section{Analysis 14.2. Comparison 14 Gemeprost I mg versus Lamicel, Outcome 2 Side-effects.}

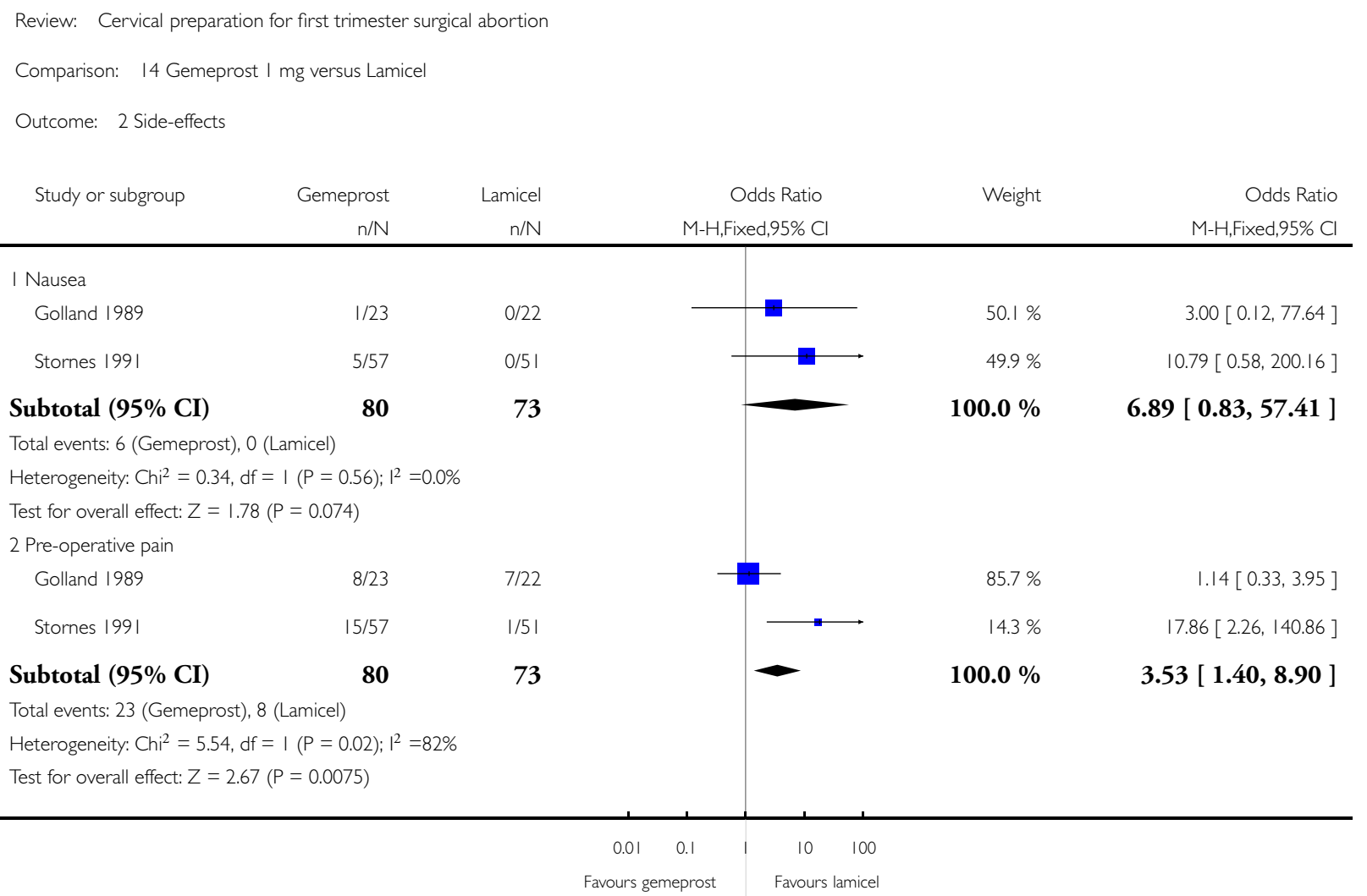


Analysis 15.I. Comparison 15 Gemeprost versus Dilapan, Outcome I Need for additional mechanical dilation.

Review: Cervical preparation for first trimester surgical abortion

Comparison: 15 Gemeprost versus Dilapan

Outcome: I Need for additional mechanical dilation

\begin{tabular}{|c|c|c|c|c|c|}
\hline \multirow[t]{2}{*}{ Study or subgroup } & Gemeprost & Dilapan & Odds Ratio & Weight & Odds Ratio \\
\hline & $\mathrm{n} / \mathrm{N}$ & $\mathrm{n} / \mathrm{N}$ & M-H,Fixed,95\% Cl & & M-H,Fixed,95\% Cl \\
\hline Golland 1989 & $7 / 23$ & $8 / 20$ & $\longrightarrow$ & $71.3 \%$ & $0.66[0.19,2.32]$ \\
\hline Jurgenson 1989 & $17 / 20$ & $16 / 20$ & 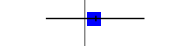 & $28.7 \%$ & $1.42[0.27,7.34]$ \\
\hline
\end{tabular}

Total $(95 \% \mathrm{CI})$

43

40

$100.0 \%$

$0.87[0.32,2.36]$

Total events: 24 (Gemeprost), 24 (Dilapan)

Heterogeneity: Chi $^{2}=0.53, \mathrm{df}=\mathrm{I}(\mathrm{P}=0.47) ; \mathrm{I}^{2}=0.0 \%$

Test for overall effect: $Z=0.26(P=0.79)$

Test for subgroup differences: Not applicable

$\begin{array}{cccc}0.01 \quad 0.1 & 1 & 10 & 100 \\ \text { Favours gemeprost } & & \text { Favours dilapan }\end{array}$




\section{Analysis 15.2. Comparison 15 Gemeprost versus Dilapan, Outcome 2 Side-effects.}

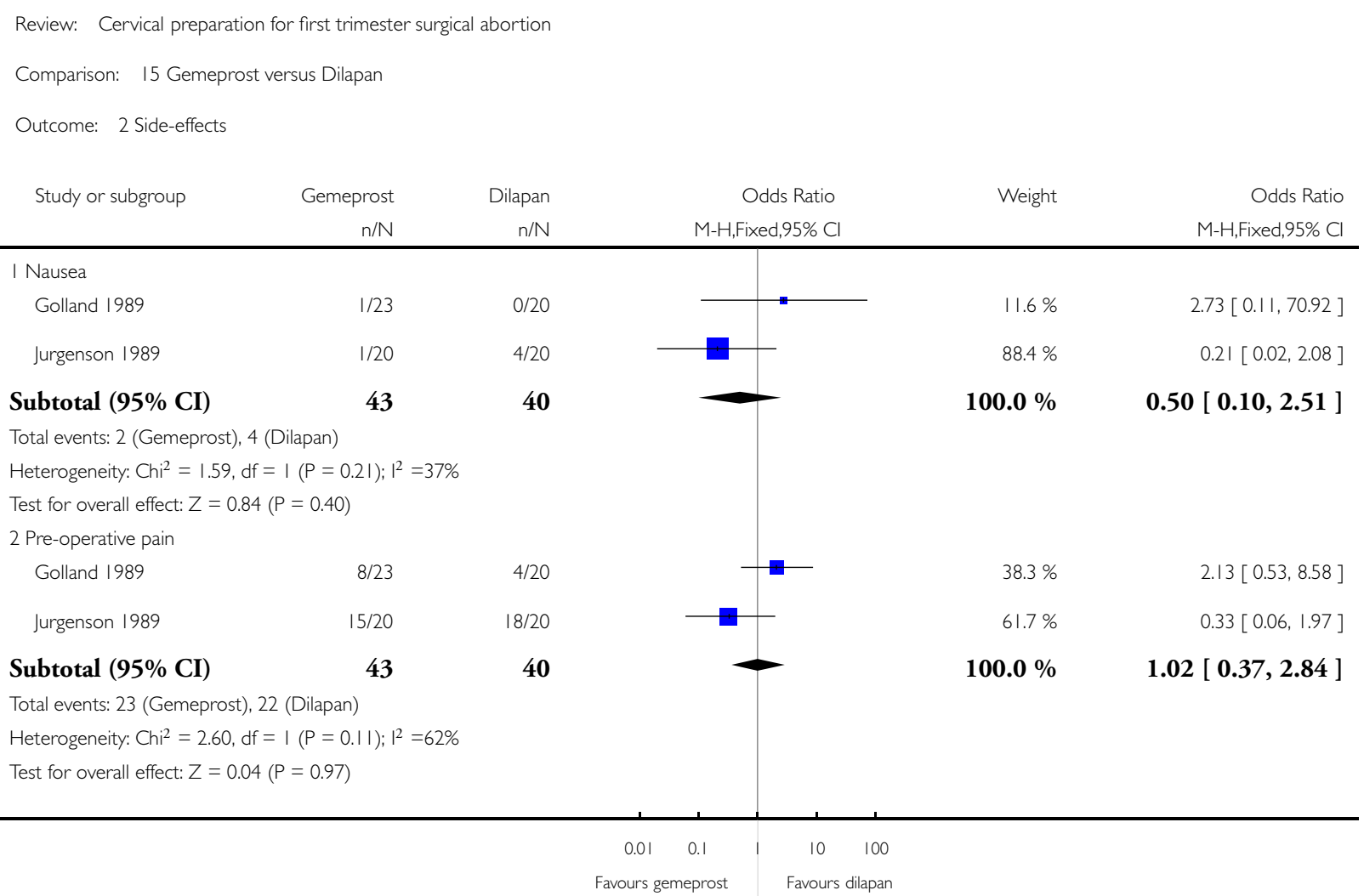


Analysis 16.1. Comparison 16 Gemeprost versus laminaria, Outcome I Need for additional mechanical dilation.

Review: Cervical preparation for first trimester surgical abortion

Comparison: 16 Gemeprost versus laminaria

Outcome: I Need for additional mechanical dilation

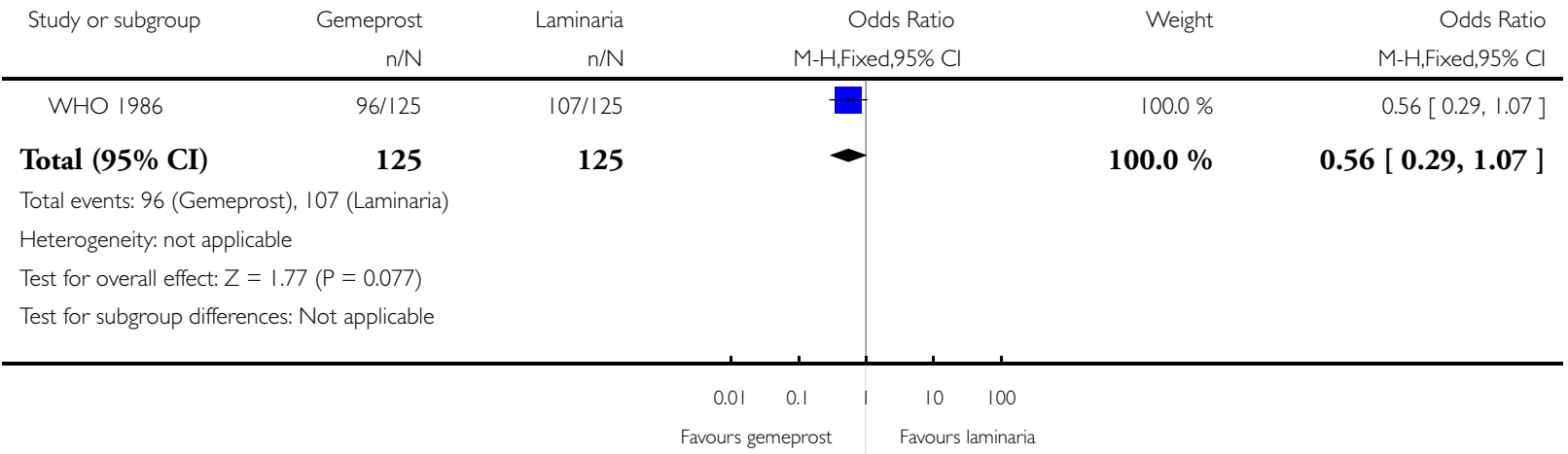

Analysis 16.2. Comparison 16 Gemeprost versus laminaria, Outcome 2 Cervical dilation at procedure start.

Review: Cervical preparation for first trimester surgical abortion

Comparison: 16 Gemeprost versus laminaria

Outcome: 2 Cervical dilation at procedure start

\begin{tabular}{|c|c|c|c|c|c|c|c|c|c|}
\hline \multirow[t]{2}{*}{ Study or subgroup } & \multirow{2}{*}{$\begin{array}{r}\text { Gemeprost } \\
N\end{array}$} & \multicolumn{2}{|r|}{ Laminaria } & \multicolumn{4}{|c|}{$\begin{array}{r}\text { Mean } \\
\text { Difference }\end{array}$} & \multirow[t]{2}{*}{ Weight } & \multirow{2}{*}{$\begin{array}{r}\text { Mean } \\
\text { Difference } \\
\text { IV,Fixed,95\% Cl }\end{array}$} \\
\hline & & Mean(SD) & N & Mean(SD) & & & $\mathrm{ked}, 95 \% \mathrm{Cl}$ & & \\
\hline WHO 1986 & 125 & $7.4(2.1)$ & 125 & $6.9(1.5)$ & & & & $100.0 \%$ & $0.50[0.05,0.95]$ \\
\hline Total (95\% CI) & 125 & & 125 & & & & $\bullet$ & $100.0 \%$ & $0.50[0.05,0.95]$ \\
\hline \multicolumn{10}{|c|}{ Heterogeneity: not applicable } \\
\hline \multicolumn{10}{|c|}{ Test for overall effect: $Z=2.17(P=0.030)$} \\
\hline \multicolumn{10}{|c|}{ Test for subgroup differences: Not applicable } \\
\hline & & & & & -10 & -5 & 0 & 10 & \\
\hline \multicolumn{10}{|c|}{ Favours gemeprost $\quad$ Favours laminaria } \\
\hline
\end{tabular}


Analysis 16.3. Comparison 16 Gemeprost versus laminaria, Outcome 3 Side-effects: nausea and vomiting.

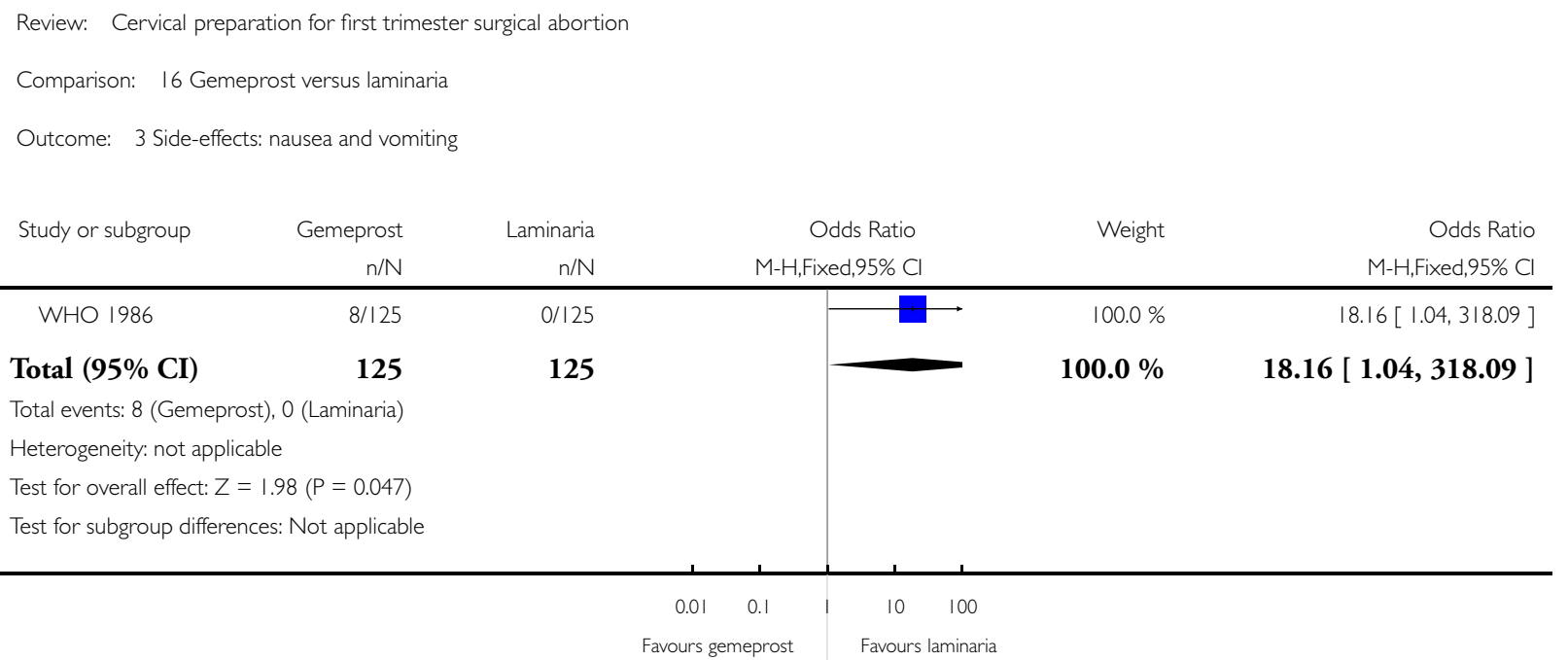

\section{Analysis 17.I. Comparison 17 Gemeprost versus prostaglandin F2 $\alpha$, Outcome I Need for additional} mechanical dilation.

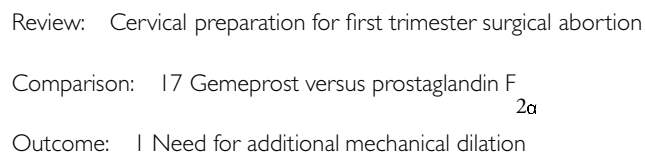

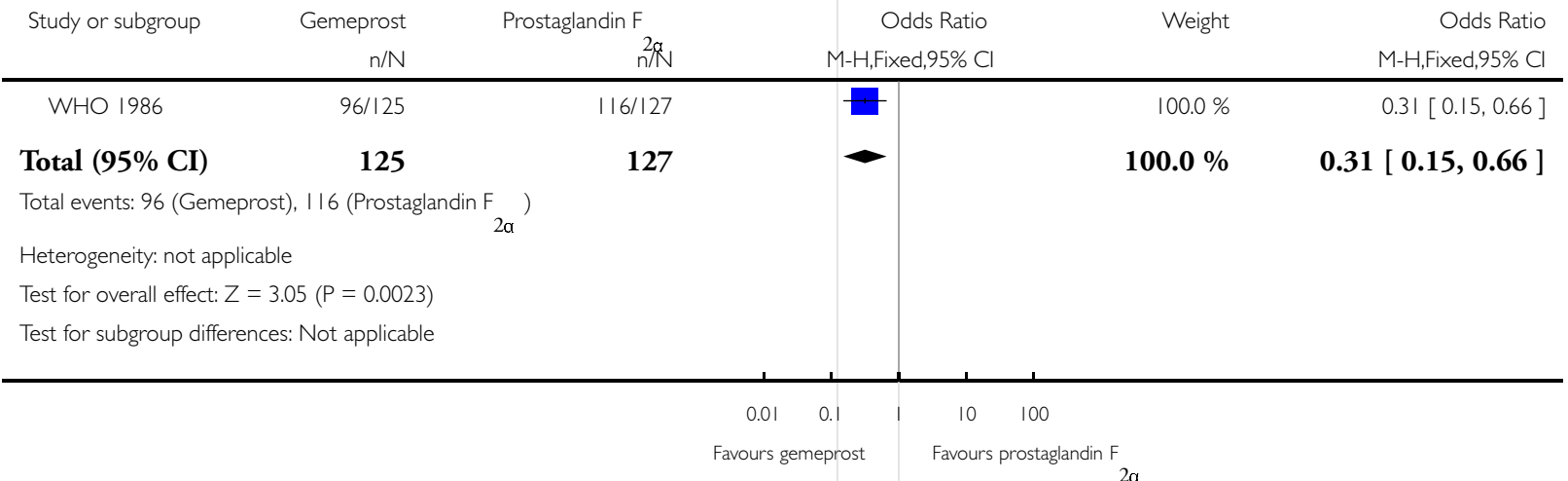


Analysis 17.2. Comparison 17 Gemeprost versus prostaglandin F2 $\alpha$, Outcome 2 Cervical dilation at procedure start.

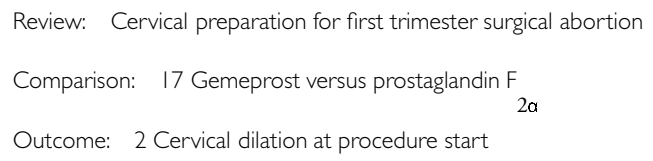

\begin{tabular}{|c|c|c|c|c|c|c|c|}
\hline \multirow[t]{2}{*}{ Study or subgroup } & Gemeprost & \multicolumn{3}{|c|}{ Prostaglandin F } & \multirow{2}{*}{$\begin{array}{c}\text { Mean } \\
\text { Difference } \\
\text { IV,Fixed,95\% Cl }\end{array}$} & \multirow[t]{2}{*}{ Weight } & $\begin{array}{r}\text { Mean } \\
\text { Difference }\end{array}$ \\
\hline & $N$ & Mean(SD) & ${ }^{2 q}$ & Mean(SD) & & & IV,Fixed,95\% Cl \\
\hline WHO 1986 & 125 & $7.4(2.1)$ & 127 & $6.5(1.8)$ & & $100.0 \%$ & $0.90[0.42,1.38]$ \\
\hline Total (95\% CI) & 125 & & 127 & & $\bullet$ & $100.0 \%$ & $0.90[0.42,1.38]$ \\
\hline
\end{tabular}

Heterogeneity: not applicable

Test for overall effect: $Z=3.65(P=0.00026)$

Test for subgroup differences: Not applicable

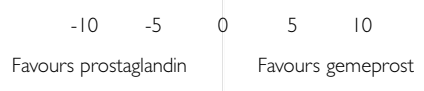

Analysis 17.3. Comparison 17 Gemeprost versus prostaglandin F2 $\alpha$, Outcome 3 Side-effects: nausea and vomiting.

Review: Cervical preparation for first trimester surgical abortion

Comparison: 17 Gemeprost versus prostaglandin F

Outcome: 3 Side-effects: nausea and vomiting

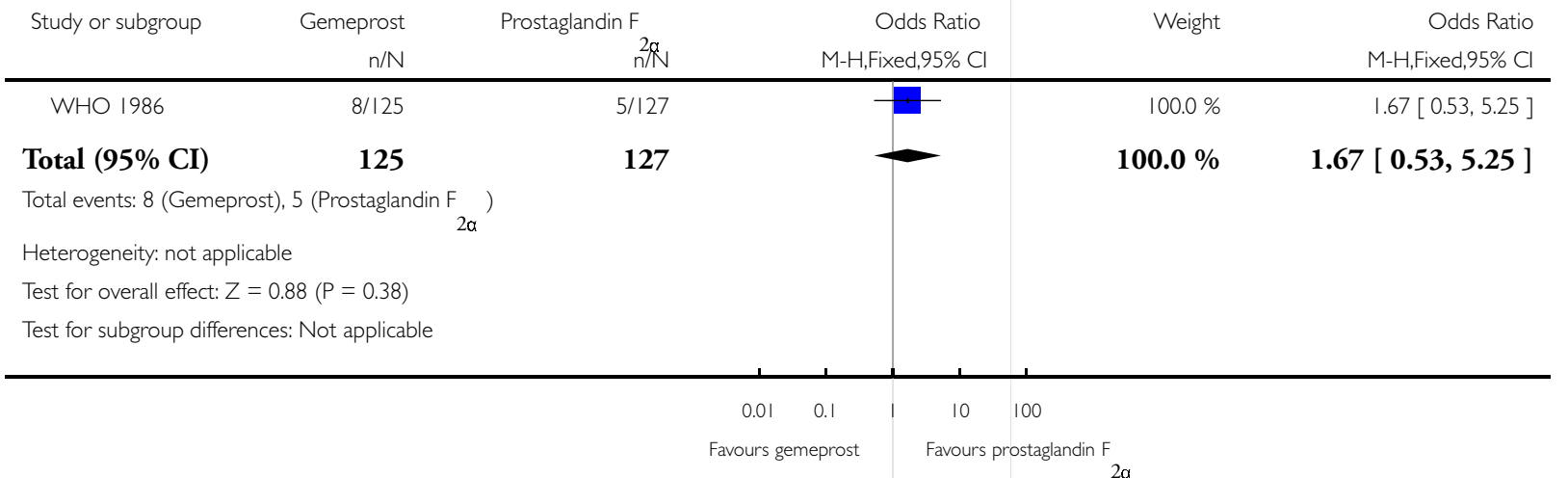




\section{Analysis 18.I. Comparison 18 Dose of mifepristone, Outcome I Need for additional mechanical dilation.}

Review: Cervical preparation for first trimester surgical abortion

Comparison: 18 Dose of mifepristone

Outcome: I Need for additional mechanical dilation

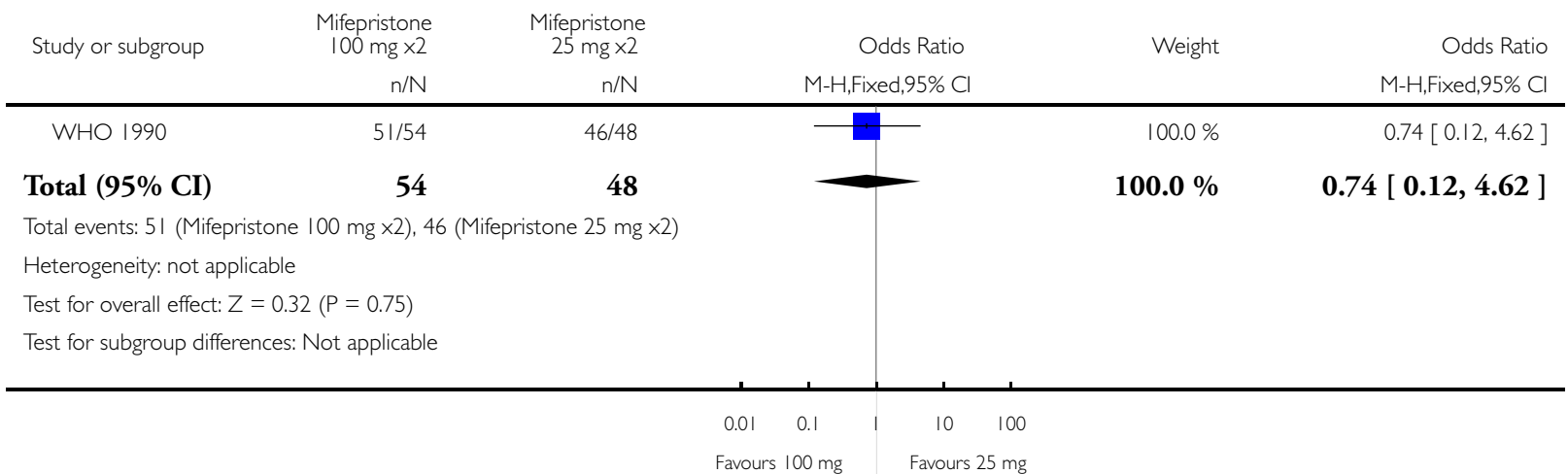

Analysis 18.2. Comparison 18 Dose of mifepristone, Outcome 2 Cervical dilation at procedure start.

Review: Cervical preparation for first trimester surgical abortion

Comparison: 18 Dose of mifepristone

Outcome: 2 Cervical dilation at procedure start

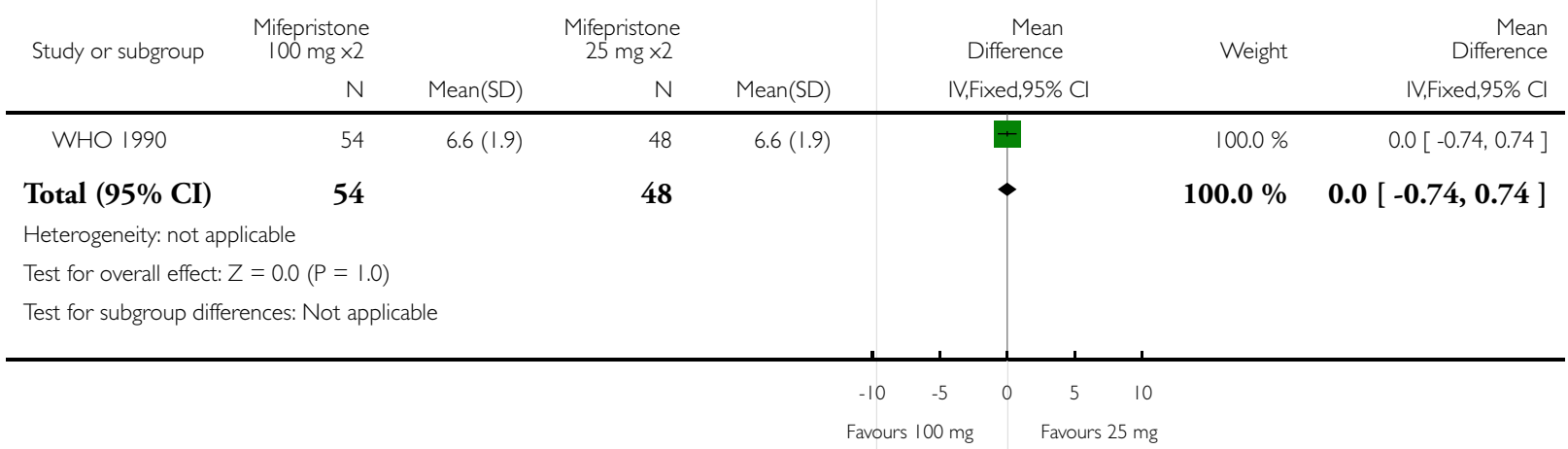




\section{Analysis 19.1. Comparison I9 Laminaria versus prostaglandin F2 $\alpha$, Outcome I Cervical dilation at} procedure start.

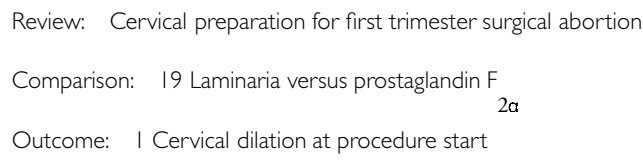
a

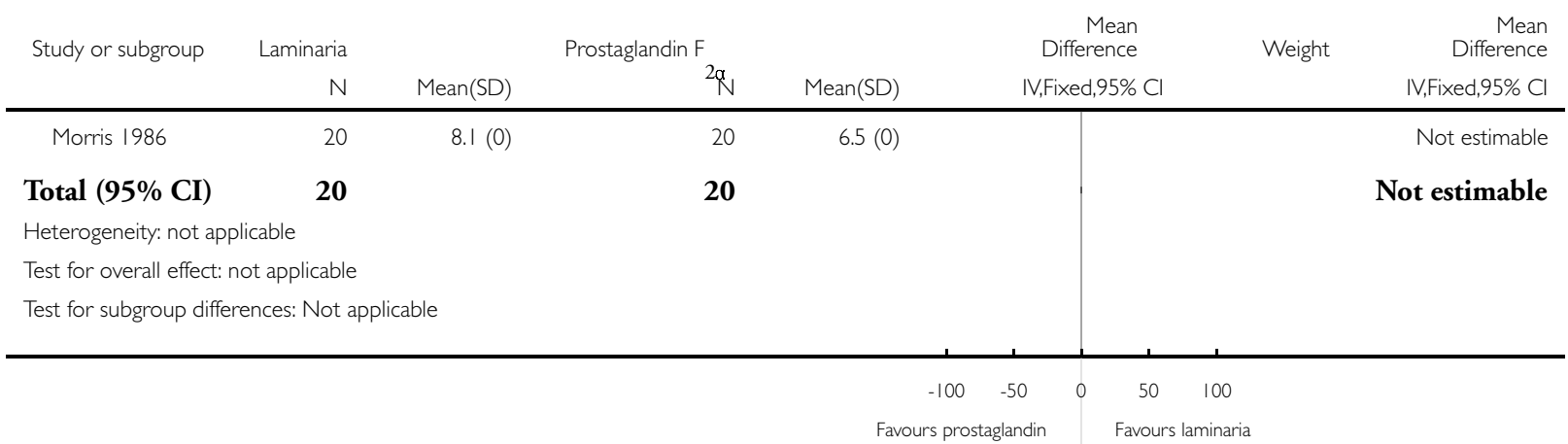

\section{Analysis 19.2. Comparison I9 Laminaria versus prostaglandin F2 $\alpha$, Outcome 2 Unplanned expulsion prior} to procedure.

Review: Cervical preparation for first trimester surgical abortion

Comparison: 19 Laminaria versus prostaglandin F

Outcome: 2 Unplanned expulsion prior to procedure

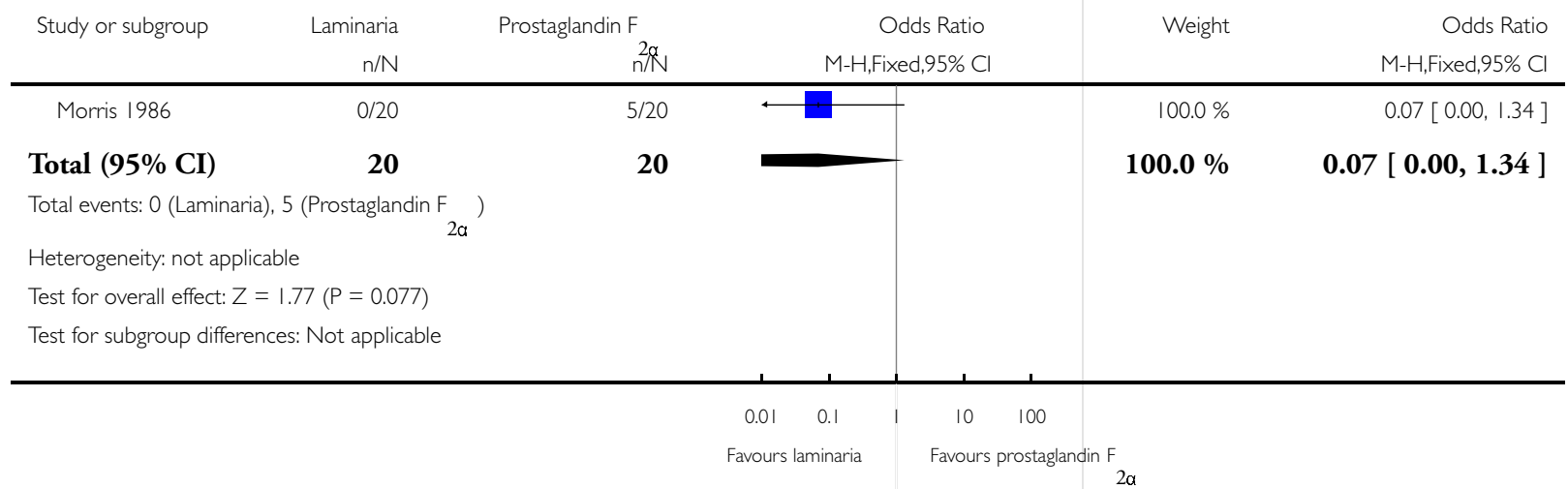




\section{Analysis 20.1. Comparison 20 Laminaria versus sulprostone, Outcome I Cervical dilation at procedure}

start.

Review: Cervical preparation for first trimester surgical abortion

Comparison: 20 Laminaria versus sulprostone

Outcome: I Cervical dilation at procedure start

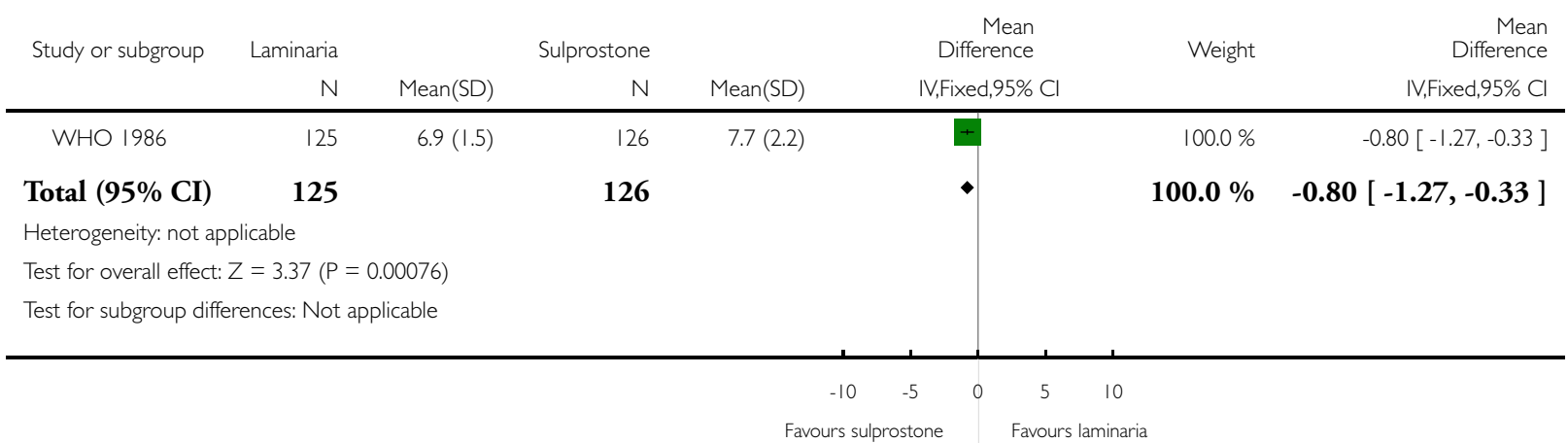

Analysis 20.2. Comparison 20 Laminaria versus sulprostone, Outcome 2 Need for additional mechanical dilation.

Review: Cervical preparation for first trimester surgical abortion

Comparison: 20 Laminaria versus sulprostone

Outcome: 2 Need for additional mechanical dilation

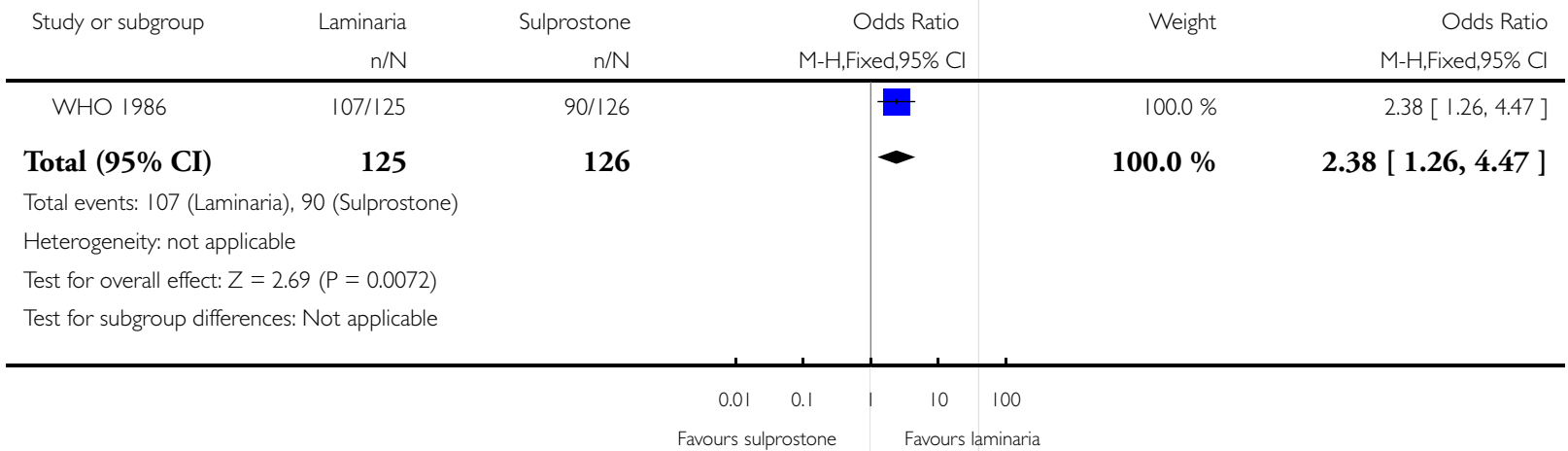


Analysis 20.3. Comparison 20 Laminaria versus sulprostone, Outcome 3 Side-effects: nausea and vomiting.

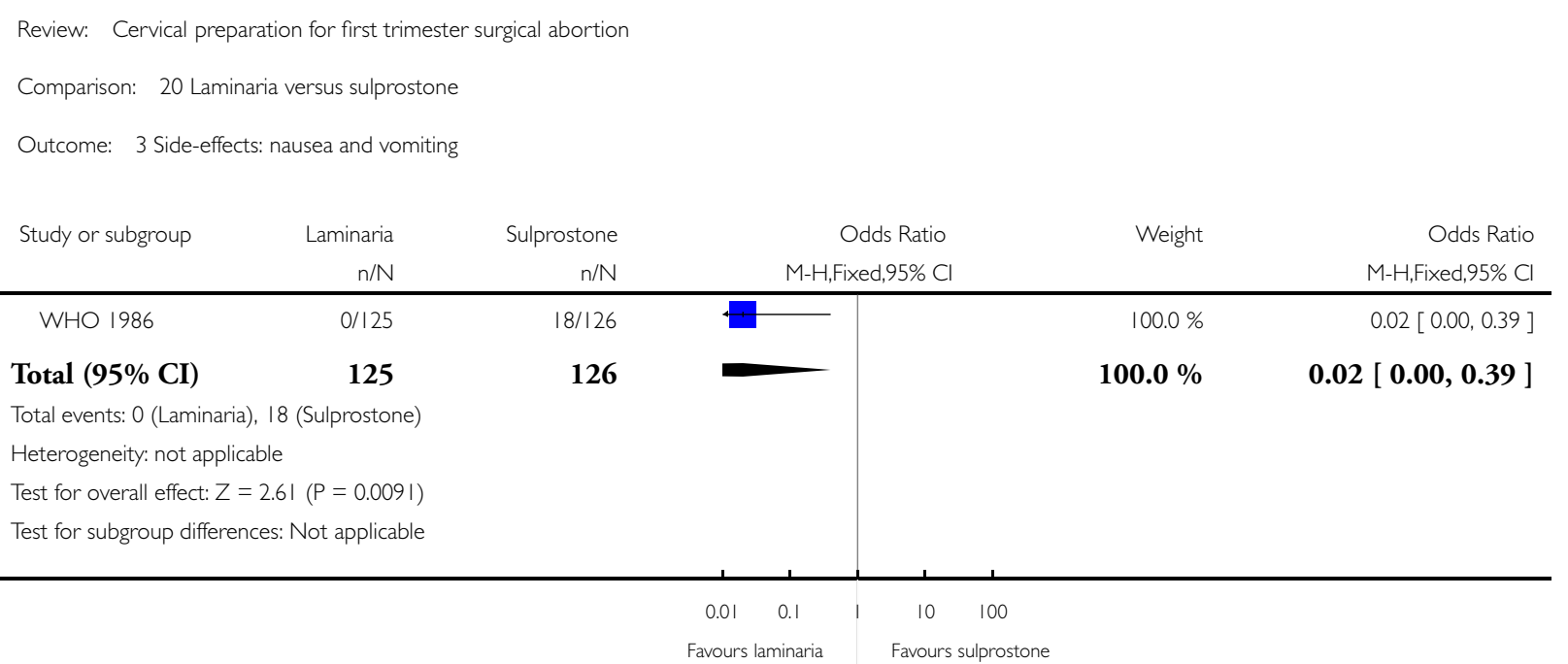

\section{Analysis 21.I. Comparison 2 I Laminaria versus PGE2, Outcome I Cervical dilation at procedure start.}

Review: Cervical preparation for first trimester surgical abortion

Comparison: 21 Laminaria versus PGE2

Outcome: I Cervical dilation at procedure start

\begin{tabular}{|c|c|c|c|c|c|c|c|}
\hline \multirow[t]{2}{*}{ Study or subgroup } & Laminaria & & $\begin{array}{r}9 \text { deoxo-16, } 16- \\
\text { dimethyl-9-methylene } \\
\text { PGE2 }\end{array}$ & & $\begin{array}{r}\text { Mean } \\
\text { Difference }\end{array}$ & \multirow[t]{2}{*}{ Weight } & \multirow{2}{*}{$\begin{array}{r}\text { Mean } \\
\text { Difference } \\
\mathrm{IV}, \text { Fixed,95\% Cl }\end{array}$} \\
\hline & $N$ & Mean(SD) & $N$ & Mean(SD) & IV,Fixed,95\% Cl & & \\
\hline WHO 1986 & 125 & $6.9(1.5)$ & 124 & $7.3(1.8)$ & & $100.0 \%$ & $-0.40[-0.81,0.01]$ \\
\hline Total (95\% CI) & 125 & & 124 & & 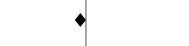 & $100.0 \%$ & $-0.40[-0.81,0.01]$ \\
\hline \multicolumn{8}{|c|}{ Heterogeneity: not applicable } \\
\hline \multicolumn{8}{|c|}{ Test for overall effect: $Z=1.90(P=0.057)$} \\
\hline \multicolumn{8}{|c|}{ Test for subgroup differences: Not applicable } \\
\hline & & & & -10 & -5 & 10 & \\
\hline \multicolumn{8}{|c|}{ Favours prostaglandin $\quad$ Favours laminaria } \\
\hline
\end{tabular}




\section{Analysis 21.2. Comparison 21 Laminaria versus PGE2, Outcome 2 Need for additional mechanical dilation.}

Review: Cervical preparation for first trimester surgical abortion

Comparison: 21 Laminaria versus PGE2

Outcome: 2 Need for additional mechanical dilation

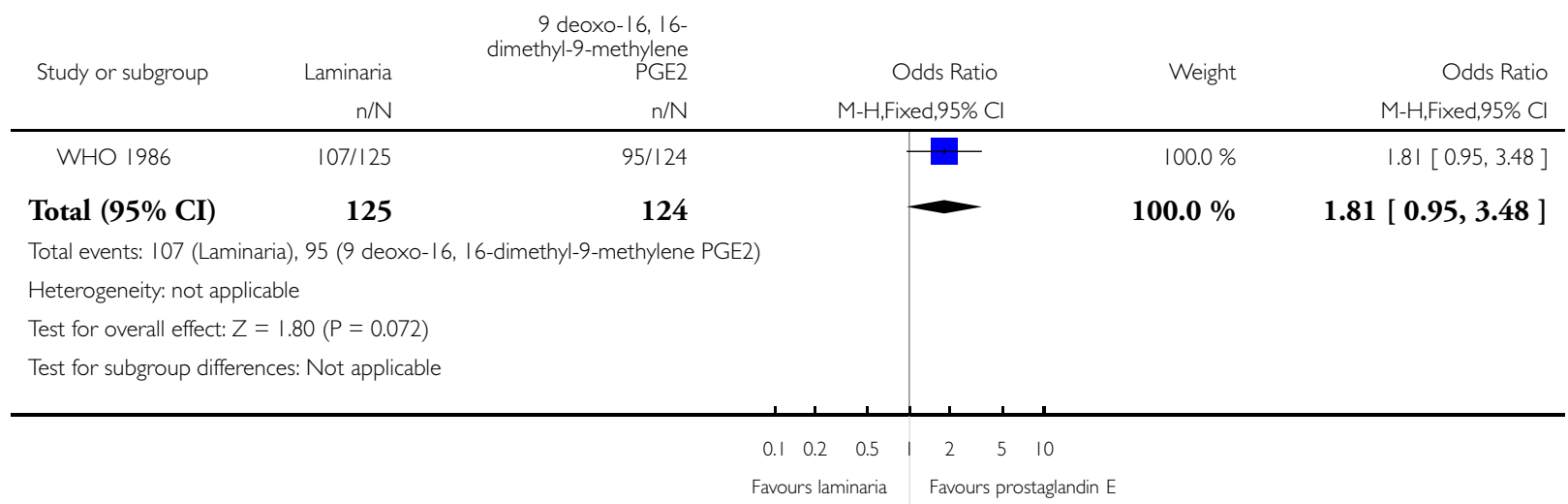

Analysis 21.3. Comparison 21 Laminaria versus PGE2, Outcome 3 Side-effects: nausea and vomiting.

Review: Cervical preparation for first trimester surgical abortion

Comparison: 21 Laminaria versus PGE2

Outcome: 3 Side-effects: nausea and vomiting

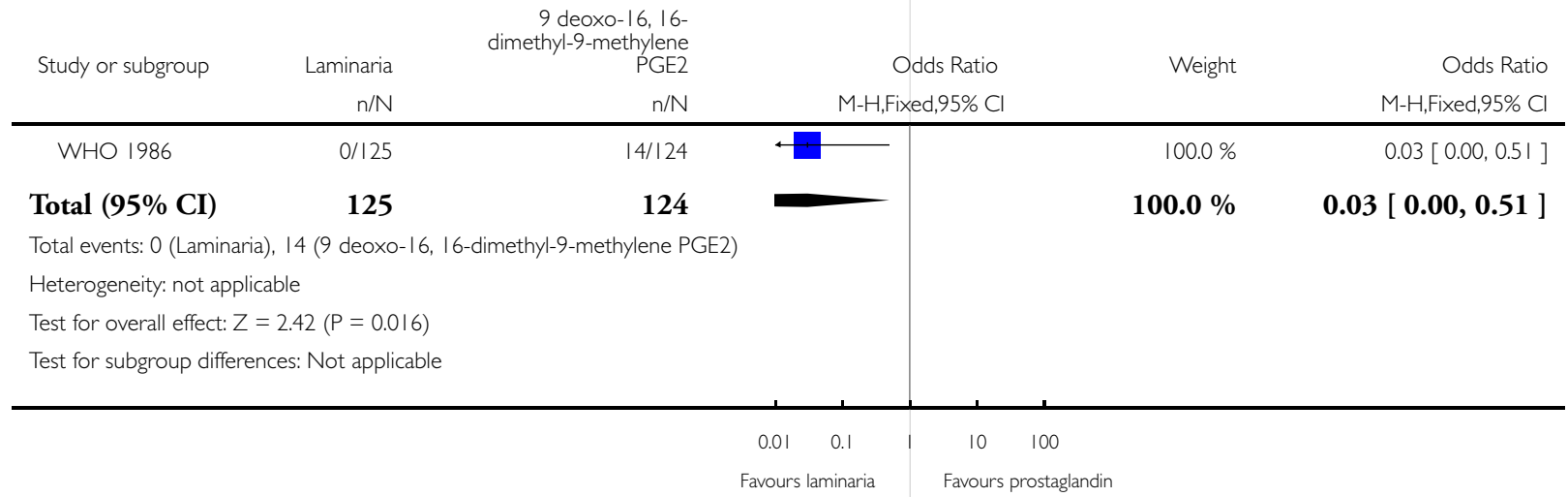


Analysis 22.I. Comparison 22 Sulprostone versus sulprostone (intracervical doses), Outcome I Need for additional mechanical dilation.

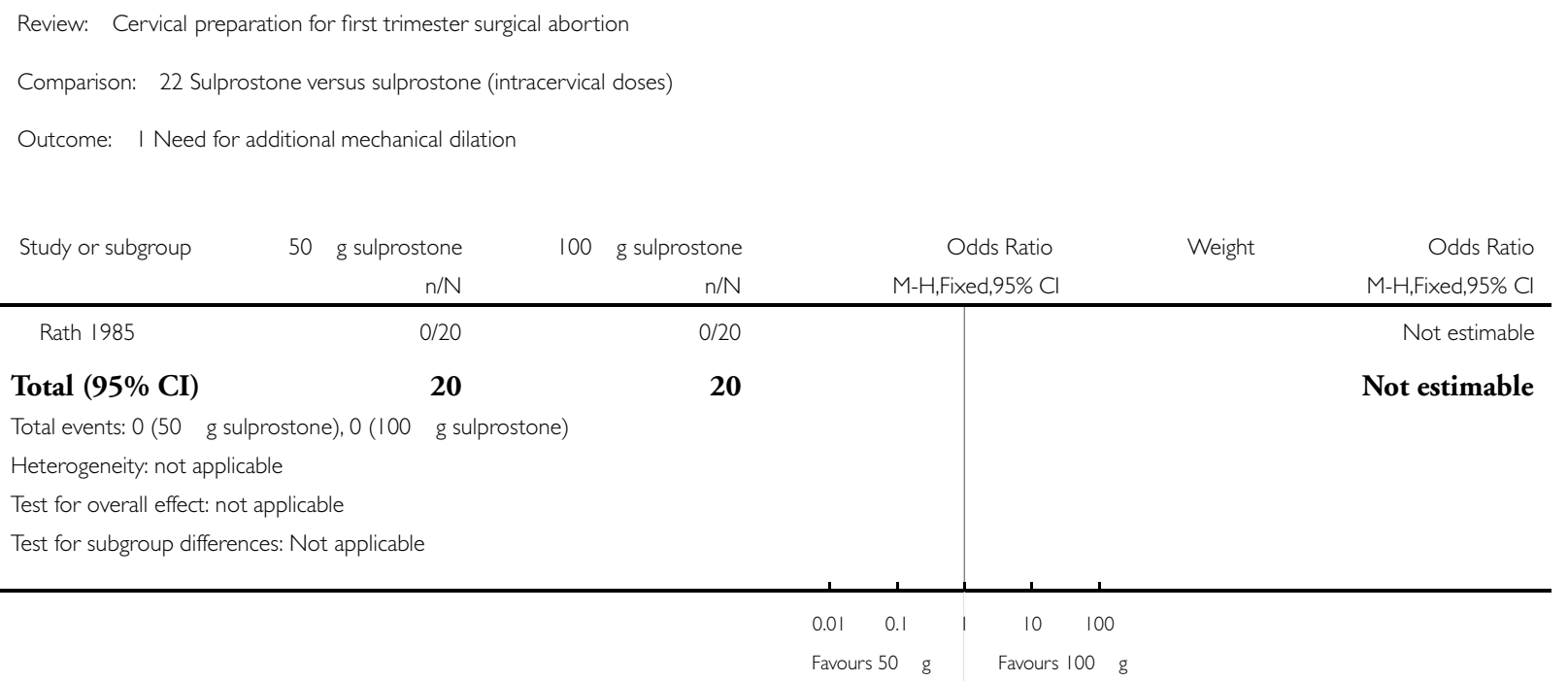

\section{Analysis 22.2. Comparison 22 Sulprostone versus sulprostone (intracervical doses), Outcome 2 Side- effects: nausea and vomiting.}

\footnotetext{
Review: Cervical preparation for first trimester surgical abortion

Comparison: 22 Sulprostone versus sulprostone (intracervical doses)

Outcome: 2 Side-effects: nausea and vomiting
}

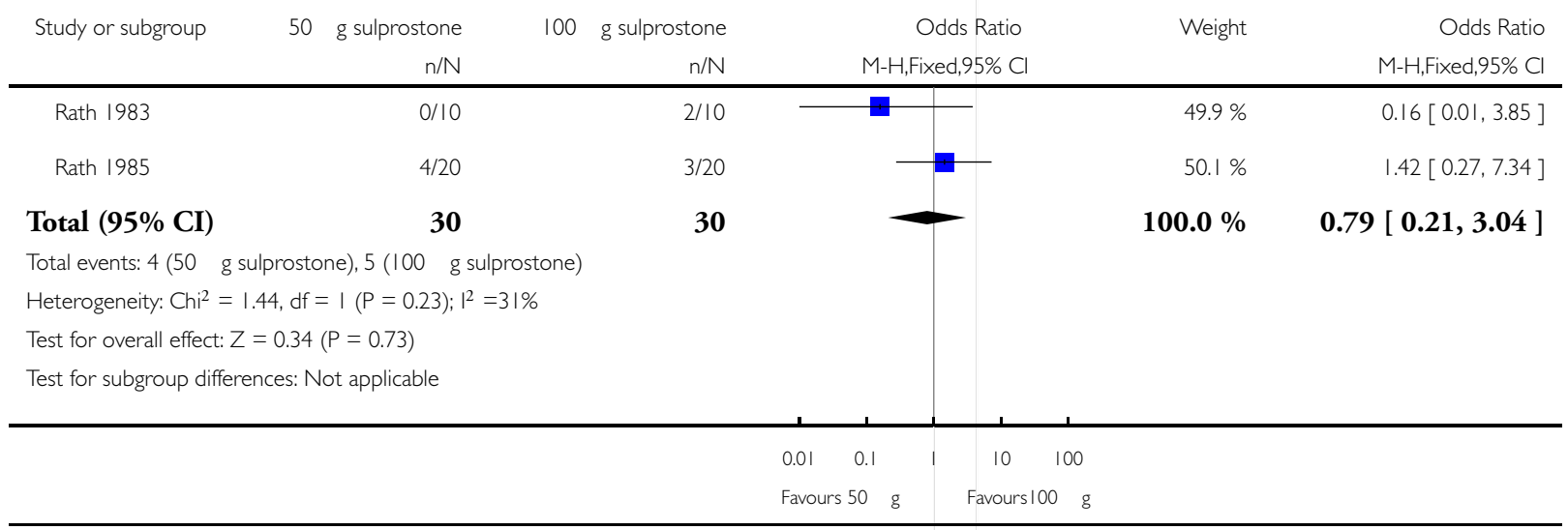




\section{Analysis 22.3. Comparison 22 Sulprostone versus sulprostone (intracervical doses), Outcome 3 Unplanned}

expulsion prior to procedure.

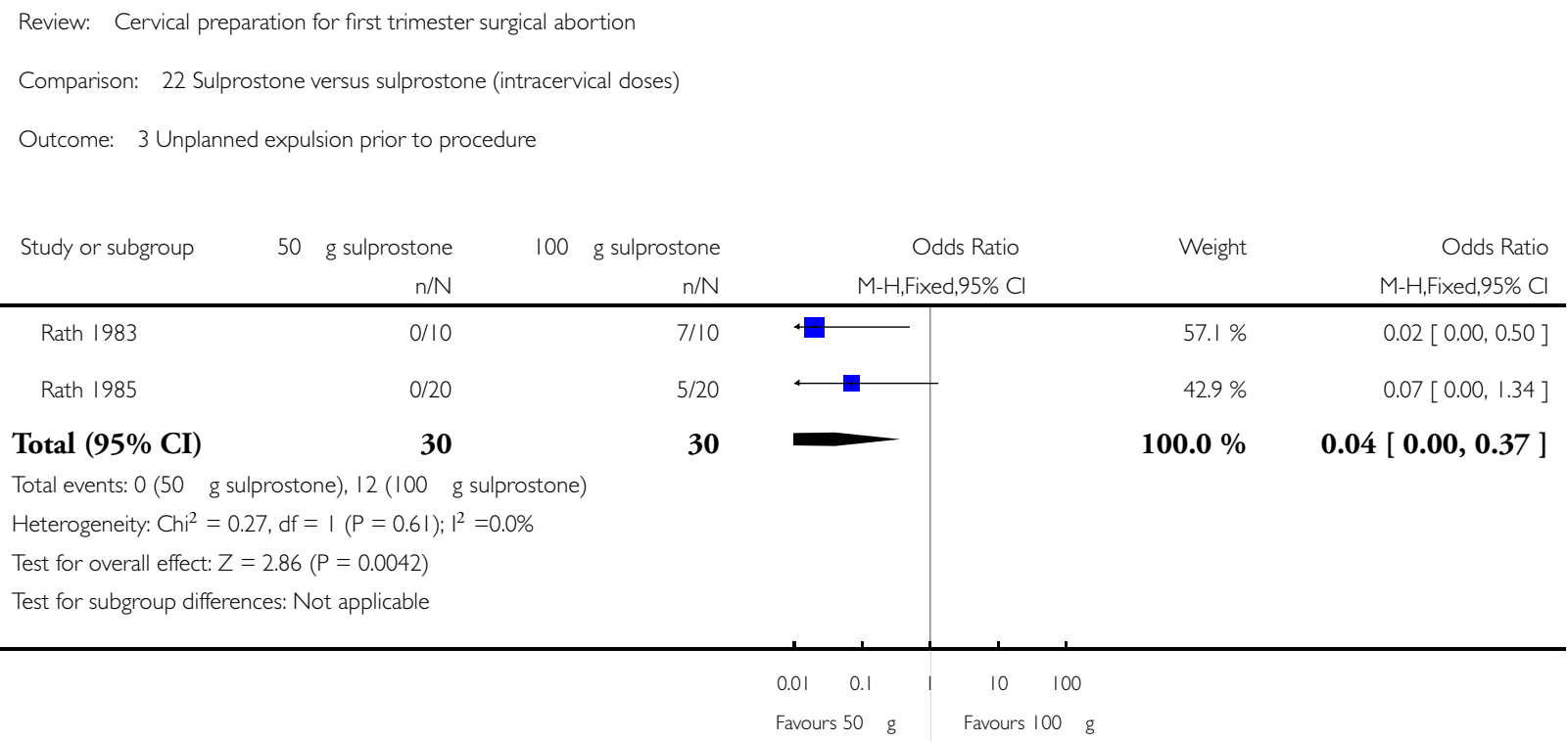


Analysis 23.I. Comparison 23 Sulprostone versus sulprostone (intramuscular doses), Outcome I Need for additional mechanical dilation.

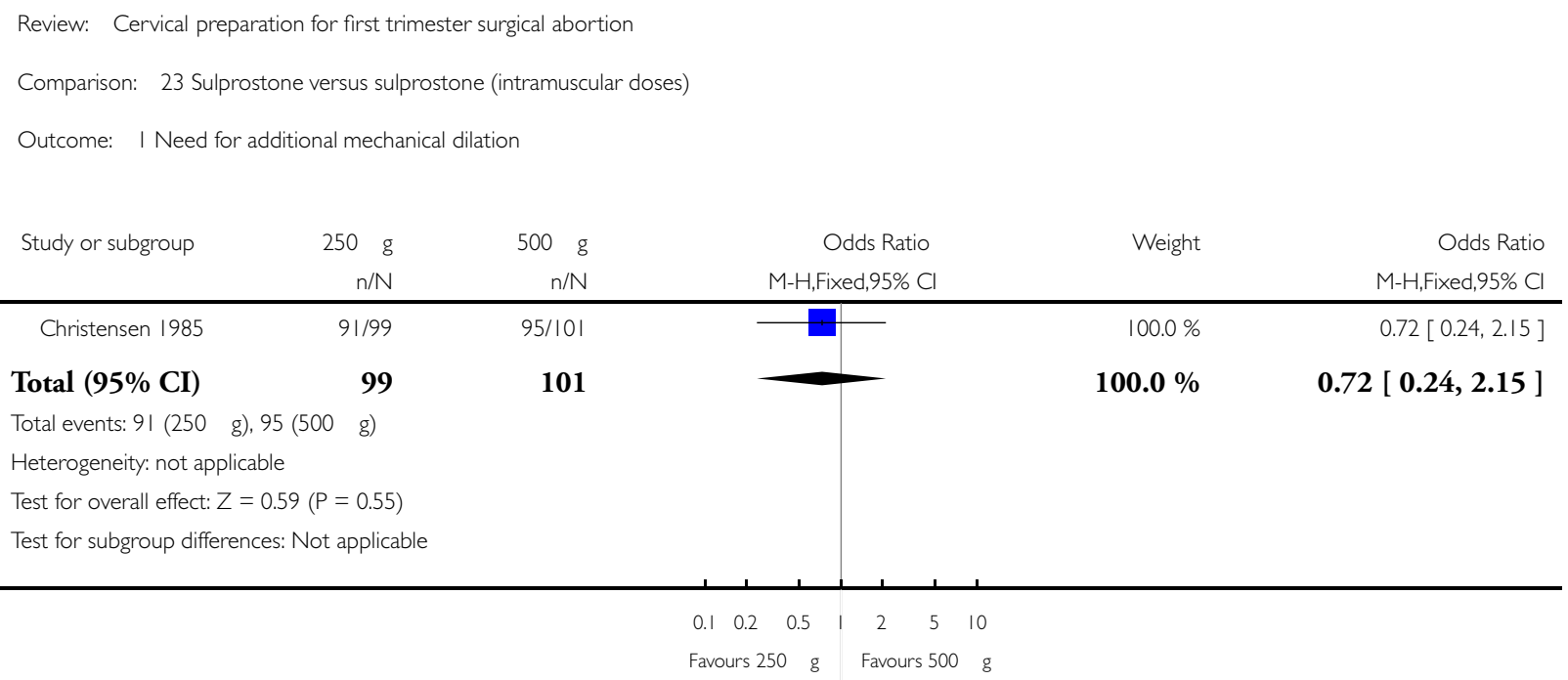

\section{Analysis 23.2. Comparison 23 Sulprostone versus sulprostone (intramuscular doses), Outcome 2 Side-} effects: nausea and vomiting.

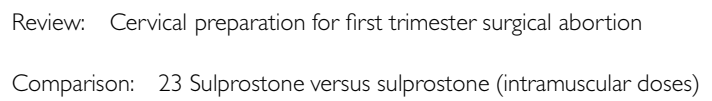

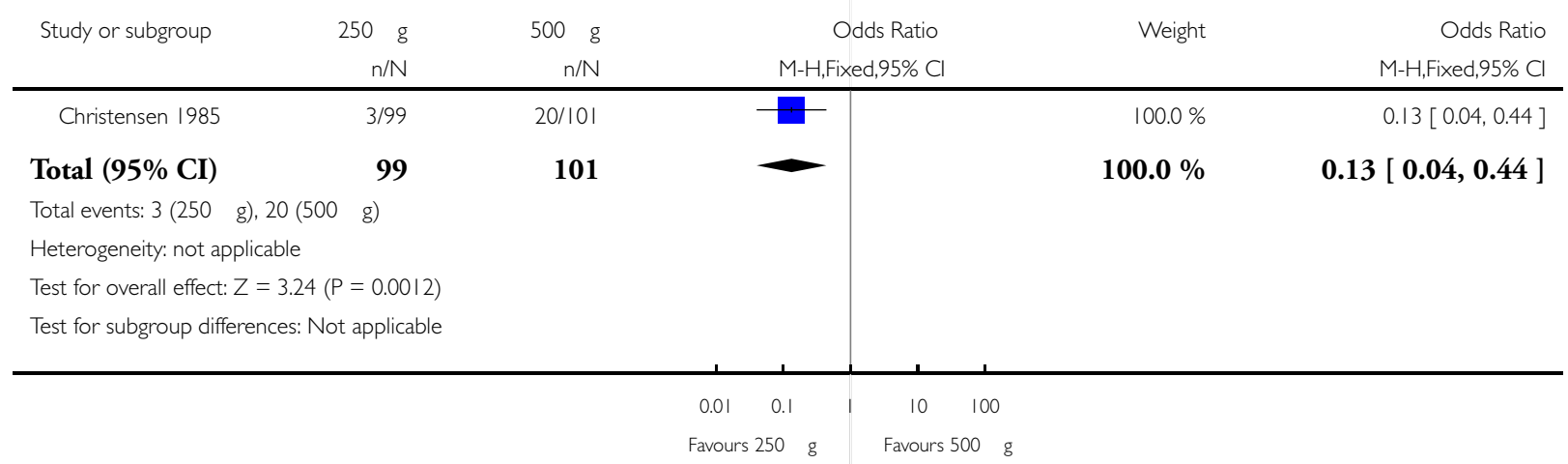


Analysis 23.3. Comparison 23 Sulprostone versus sulprostone (intramuscular doses), Outcome 3 Unplanned expulsion prior to procedure.

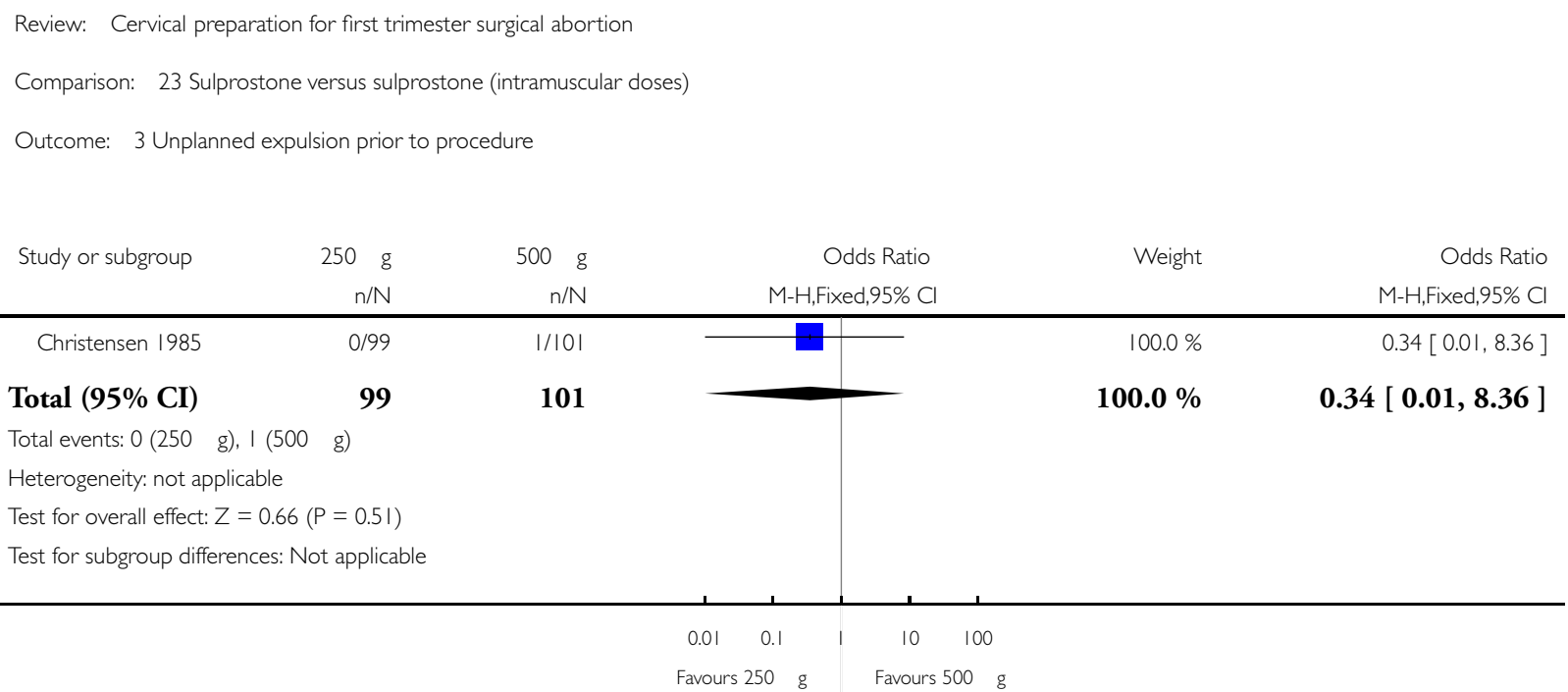

Analysis 24.I. Comparison 24 Prostaglandin E2 versus prostaglandin F2 $\alpha$, Outcome I Need for additional mechanical dilation.

Review: Cervical preparation for first trimester surgical abortion

Comparison: 24 Prostaglandin $E_{2}$ versus prostaglandin $F$

Outcome: I Need for additional mechanical dilation

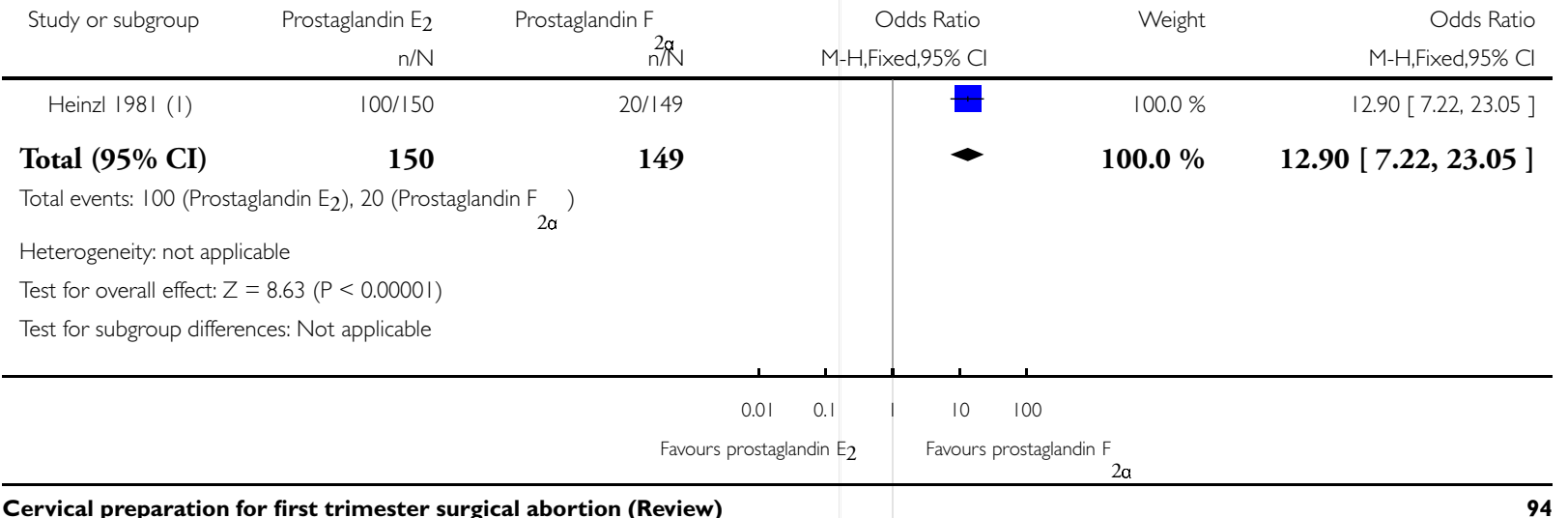

Copyright $\odot 2010$ The Cochrane Collaboration. Published by John Wiley \& Sons, Ltd. 
( I) I mg oral prostaglandins $E_{2}$ was compared with $2.5 \mathrm{mg}$ intracervical $\mathrm{F}$

$2 \alpha$

Analysis 24.2. Comparison 24 Prostaglandin E2 versus prostaglandin F2 $\alpha$, Outcome 2 Side-effects: nausea and vomiting.

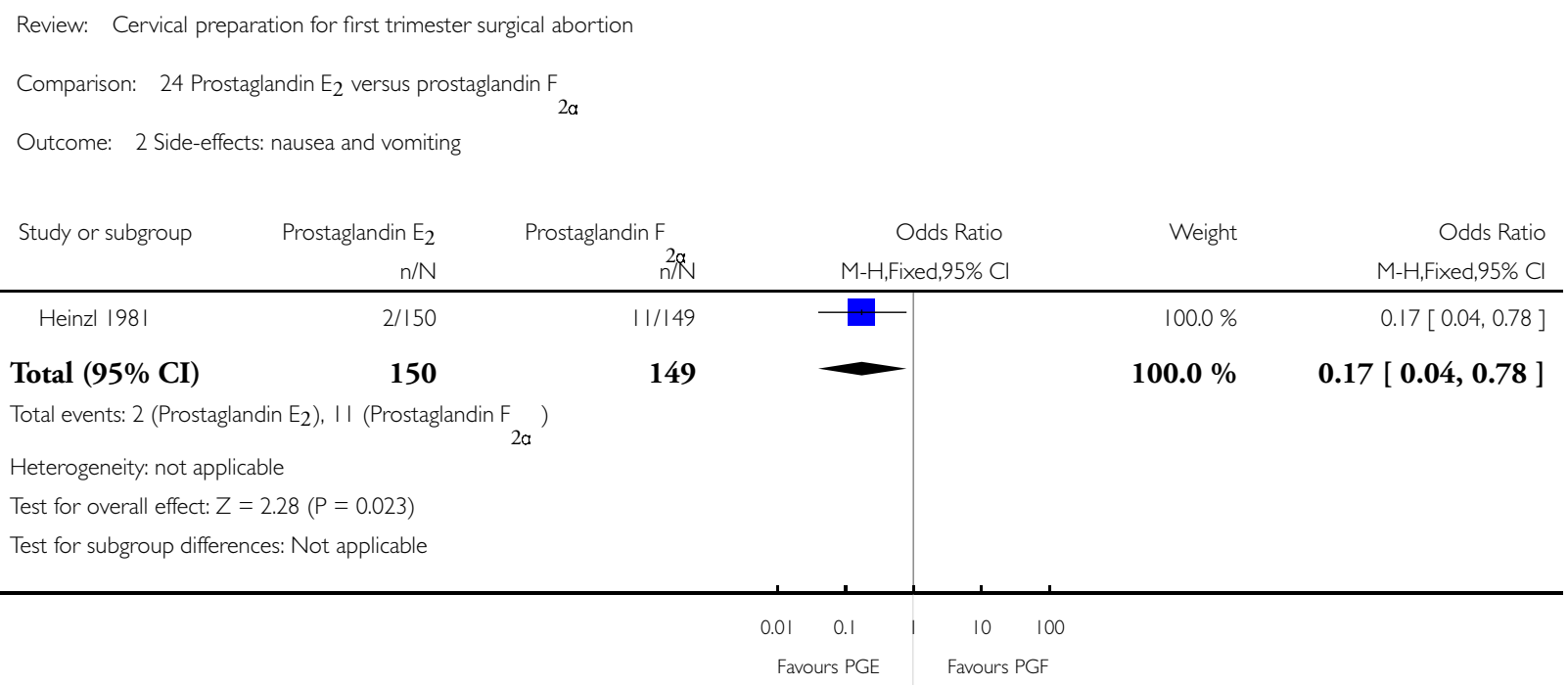


Analysis 24.3. Comparison 24 Prostaglandin E2 versus prostaglandin F2 $\alpha$, Outcome 3 Unplanned expulsion prior to procedure.

Review: Cervical preparation for first trimester surgical abortion

Comparison: 24 Prostaglandin $E_{2}$ versus prostaglandin $F_{2}$

Outcome: 3 Unplanned expulsion prior to procedure

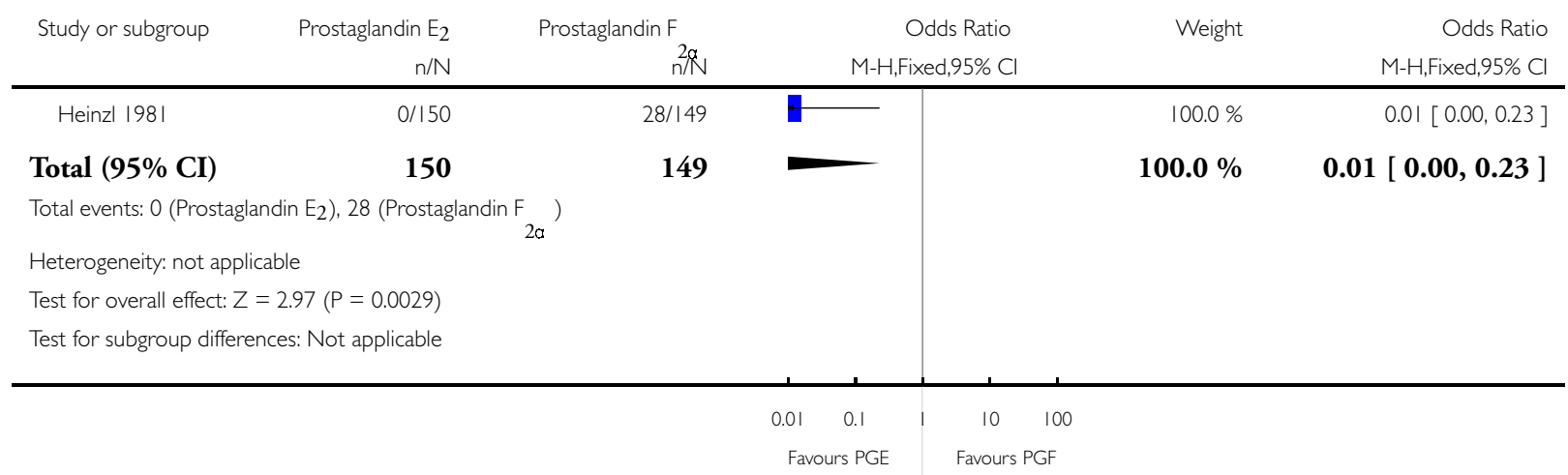

Analysis 25.1. Comparison 25 Lamicel versus synthetic sponge without MgSO4, Outcome I Unplanned expulsion prior to procedure.

Review: Cervical preparation for first trimester surgical abortion
Comparison: 25 Lamicel versus synthetic sponge without $\mathrm{MgSO}_{4}$
Outcome: I Unplanned expulsion prior to procedure

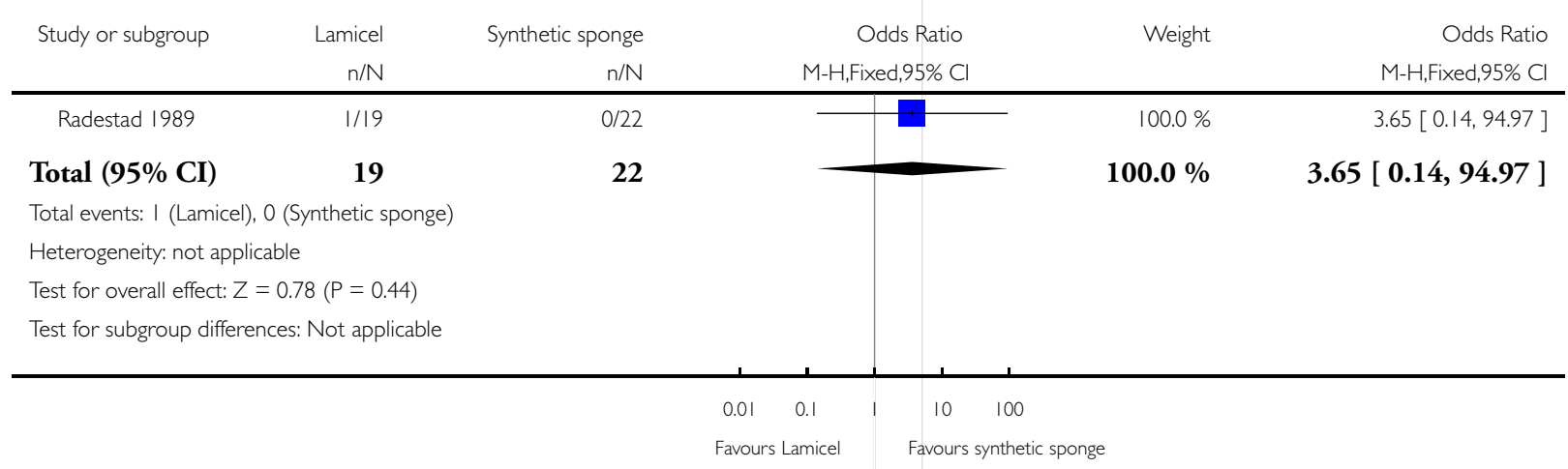


ADDITIONAL TABLES

Table 1. Placebo versus misoprostol

\begin{tabular}{lllll}
\hline Study & Treatment & N & Cervical dilation (mm) \\
\hline Inal 2003 & placebo & 60 & 5.9 \\
\hline & $200 \mu \mathrm{g}$ oral misoprostol & 30 & 6.5 \\
\hline Wiebe 1998 & $200 \mu \mathrm{g}$ vaginal misoprostol & 30 & 6.6 \\
\hline & placebo & 47 & 6.2 \\
\hline Okanlomo 1999 & placebo & 46 & 6.8 \\
\hline & $\begin{array}{l}600 \mu \mathrm{g} \text { vaginal misoprostol } \\
\text { prior }+ \\
400 \mu \mathrm{g} \text { misoprostol } 4 \text { h prior }\end{array}$ & 66 & $\begin{array}{l}\text { nulli } 2.5 \\
\text { multi } 3.9\end{array}$ \\
\hline
\end{tabular}

Table 2. Placebo versus PGF $_{2 \alpha}$

\begin{tabular}{|c|c|c|c|}
\hline Study & Treatment & $\mathbf{N}$ & Cervical dilation (mm) \\
\hline \multirow[t]{2}{*}{ Wang 1989} & placebo & 30 & 4.3 \\
\hline & $1 \mathrm{mg}$ supp. $\mathrm{PGF}_{2 \alpha}$ & 30 & 6.6 \\
\hline \multirow[t]{2}{*}{ Morris 1986} & placebo & 20 & 4.9 \\
\hline & $20 \mathrm{mg} \mathrm{PGF}_{2 \alpha}$ gel & 20 & 6.5 \\
\hline
\end{tabular}

Table 3. Misoprostol administrative routes

\begin{tabular}{|c|c|c|c|c|}
\hline Study & Treatment & $\mathbf{N}$ & Cervical dilation (mm) & \\
\hline \multicolumn{5}{|c|}{ Oral (or) vs vaginal (v) } \\
\hline \multirow[t]{2}{*}{ Ashok 2003} & $400 \mu \mathrm{g}$ or. & 32 & 7.0 & \\
\hline & $800 \mu \mathrm{g} \mathrm{v}$ & 32 & 7.0 & \\
\hline \multirow[t]{2}{*}{ Carbonell 2001} & $400 \mu \mathrm{g}$ or. & 450 & 8.1 & \\
\hline & $400 \mu \mathrm{g} \mathrm{v}$ & 450 & 8.5 & \\
\hline
\end{tabular}

Copyright $\odot 2010$ The Cochrane Collaboration. Published by John Wiley \& Sons, Ltd. 
Table 3. Misoprostol administrative routes (Continued)

\begin{tabular}{l|lll}
\hline Inal 2003 & $200 \mu \mathrm{g}$ or. & 30 & 6.5 \\
\hline & $200 \mu \mathrm{g} \mathrm{v}$. & 30 & 6.5 \\
\hline Oppegaard 2006 & $400 \mu \mathrm{g}$ or. & 163 & 6.5 \\
\hline & $400 \mu \mathrm{g} \mathrm{v}$. & 158 & 6.2 \\
\hline Vaginal (v) vs sublingual (s) & & & \\
\hline Hamoda 2004 & $400 \mu \mathrm{g} v$ & 37 & 7.5 \\
\hline & $400 \mu \mathrm{g} \mathrm{s.}$ & 37 & 8.0 \\
\hline
\end{tabular}

Table 4. Misoprostol versus gemeprost

\begin{tabular}{|c|c|c|c|}
\hline Study & Treatment & $\mathbf{N}$ & Cervical dilation (mm) \\
\hline \multirow[t]{2}{*}{ El-Rafaey 1994} & $600 \mu \mathrm{g}$ misoprostol & 30 & 8.0 \\
\hline & $1 \mathrm{mg}$ gemeprost & 30 & 8.0 \\
\hline
\end{tabular}

Table 5. $\mathbf{P G F}_{2 \alpha}$ versus laminaria

\begin{tabular}{|c|c|c|c|}
\hline Study & Treatment & $\mathbf{N}$ & Cervical dilation $(\mathrm{mm})$ \\
\hline \multirow[t]{2}{*}{ Morris 1986} & $20 \mathrm{mg} \mathrm{PGF}{ }_{2 \alpha}$ gel & 20 & 6.5 \\
\hline & Laminaria & 20 & 8.1 \\
\hline
\end{tabular}

Table 6. Sulprostone doses

\begin{tabular}{l|l|l|l}
\hline Study & Treatment & N & Cervical dilation $(\mathbf{m m})$ \\
\hline Rath 1983 & 0.05 sulprostone gel & 10 & 10 \\
\hline & 0.1 mg sulprostone gel & 10 & $>10$ \\
\hline
\end{tabular}


Table 7. Lamicel versus synthetic sponge

\begin{tabular}{l|lll}
\hline Study & Treatment & N & Cervical dilatation (mm) \\
\hline Radestad 1989 & Lamicel $(3 \mathrm{~mm})$ & 19 & 4.4 \\
\hline & Synthetic sponge (no $\left.\mathrm{MgSo}_{4}\right)$ & 22 & 4.1 \\
\hline
\end{tabular}

\section{WHAT'S NEW}

Last assessed as up-to-date: 9 October 2009.

\begin{tabular}{l|l|l}
\hline Date & Event & Description \\
\hline 3 February 2010 & Amended & text improved \\
\hline
\end{tabular}

\section{H IS T O R Y}

Protocol first published: Issue 3, 2008

Review first published: Issue 2, 2010

\section{CONTRIBUTIONSOFAUTHORS}

JH had the idea and NK wrote the review and conducted the analyses. NK and TN extracted and entered the data. All authors read, edited and advised on the text of the review.

\section{DECLARATIONSOF INTEREST}

Two authors (JH and PL) provide abortions in clinical practice.

\section{SOURCES OF SUPPORT}




\section{Internal sources}

- Department of Reproductive Health and Research, World Health Organization, Switzerland.

\section{External sources}

- No sources of support supplied

\section{DIFFERENCES BETWEEN PROTOCOLANDREVIEW}

Addition of the authors Nathalie Kapp and Thoai Ngo.

\section{NDEX TERMS}

\section{Medical Subject Headings (MeSH)}

Abortifacient Agents, Nonsteroidal [*administration \& dosage; adverse effects]; Abortion, Induced [* methods]; Alprostadil [administration \& dosage; analogs \& derivatives]; Cervical Ripening [* drug effects]; Dinoprost [administration \& dosage]; Dinoprostone [administration \& dosage; analogs \& derivatives]; Mifepristone [administration \& dosage]; Misoprostol [administration \& dosage]; Pregnancy Trimester, First

\section{MeSH check words}

Female; Humans; Pregnancy 